\title{
Transient Receptor Potential channels (TRP) in GtoPdb v.2021.3
}

\author{
1. Harvard Medical School, USA \\ 2. UCSF School of Medicine, USA \\ 3. Yale University, USA \\ 4. University of California San Francisco, USA \\ 5. University of Southern California, USA \\ 6. Katholieke Universiteit Leuven, Belgium \\ 7. Brown University, USA \\ 8. University of Iowa, USA \\ 9. The University of Texas Health Science Center at Houston, USA \\ 10. KU Leuven, Belgium \\ 11. Rutgers University, USA \\ 12. University of Michigan, USA \\ 13. University of Connecticut School of Medicine, USA
}

Nathaniel T. Blair ${ }^{1}$, Ingrid Carvacho ${ }^{1}$, Dipayan Chaudhuri ${ }^{1}$, David E. Clapham ${ }^{1}$, Paul DeCaen ${ }^{1}$, Markus Delling ${ }^{2}$, Julia F. Doerner ${ }^{1}$, Lu Fan ${ }^{3}$, Kotdaji $\mathrm{Ha}^{2}$, Sven E. Jordt ${ }^{3}$, David Julius ${ }^{4}$, Kristopher T Kahle $^{1}$, Boyi Liu ${ }^{3}$, David McKemy ${ }^{5}$, Bernd Nilius ${ }^{6}$, Elena Oancea ${ }^{7}$, Grzegorz Owsianik ${ }^{6}$, Antonio Riccio $^{1}$, Rajan Sah ${ }^{8}$, Stephanie C. Stotz ${ }^{1}$, Jinbin Tian ${ }^{9}$, Dan Tong ${ }^{1}$, Charlotte Van den Eynde ${ }^{10}$, Joris Vriens $^{10}$, Long-Jun $\mathrm{Wu}^{11}$, Haoxing Xu${ }^{12}$, Lixia Yue ${ }^{13}$, Xiaoli Zhang ${ }^{12}$ and Michael X. Zhu ${ }^{9}$

\begin{abstract}
The TRP superfamily of channels (nomenclature as agreed by NC-IUPHAR [159, 997]), whose founder member is the Drosophila Trp channel, exists in mammals as six families; TRPC, TRPM, TRPV, TRPA, TRPP and TRPML based on amino acid homologies. TRP subunits contain six putative TM domains and assemble as homo- or hetero-tetramers to form cation selective channels with diverse modes of activation and varied permeation properties (reviewed by [679]). Established, or potential, physiological functions of the individual members of the TRP families are discussed in detail in the recommended reviews and in a number of books [371, 635, 1064, 236]. The established, or potential, involvement of TRP channels in disease is reviewed in [412, 634] and [637], together with a special edition of Biochemica et Biophysica Acta on the subject [634]. Additional disease related reviews, for pain [585], stroke [1050], sensation and inflammation [919], itch [117], and airway disease [284, 977], are available. The pharmacology of most TRP channels has been advanced in recent years. Broad spectrum agents are listed in the tables along with more selective, or recently recognised, ligands that are flagged by the inclusion of a primary reference. See Rubaiy (2019) for a review of pharmacological tools for TRPC1/C4/C5 channels [751]. Most TRP channels are regulated by phosphoinostides such as PtIns $(4,5) \mathrm{P}_{2}$ although the effects reported are often complex, occasionally contradictory, and likely to be dependent upon experimental conditions, such as intracellular ATP levels (reviewed by [939, 638, 747]). Such regulation is generally not included in the tables. When thermosensitivity is mentioned, it refers specifically to a high Q10 of gating, often in the range of 10-30, but does not necessarily imply that the channel's function is to act as a 'hot' or 'cold' sensor. In general, the search for TRP activators has led to many claims for temperature sensing, mechanosensation, and lipid sensing. All proteins are of course sensitive to energies of binding, mechanical force, and temperature, but the issue is whether the proposed input is within a physiologically relevant range resulting in a response.
\end{abstract}

TRPA (ankyrin) family

TRPA1 is the sole mammalian member of this group (reviewed by [268]). TRPA1 activation of sensory neurons contribute to nociception [382, 829, 555]. Pungent chemicals such as mustard oil (AITC), allicin, and cinnamaldehyde activate TRPA1 by modification of free thiol groups of cysteine side chains, especially those located in its amino terminus [529, 51, 336, 531]. Alkenals with $\alpha, \beta$ - 
unsaturated bonds, such as propenal (acrolein), butenal (crotylaldehyde), and 2-pentenal can react with free thiols via Michael addition and can activate TRPA1. However, potency appears to weaken as carbon chain length increases $[23,51]$. Covalent modification leads to sustained activation of TRPA1. Chemicals including carvacrol, menthol, and local anesthetics reversibly activate TRPA1 by non-covalent binding [391, 470, 1005, 1004]. TRPA1 is not mechanosensitive under physiological conditions, but can be activated by cold temperatures [392, 193]. The electron cryo-EM structure of TRPA1 [688] indicates that it is a 6-TM homotetramer. Each subunit of the channel contains two short 'pore helices' pointing into the ion selectivity filter, which is big enough to allow permeation of partially hydrated $\mathrm{Ca}^{2+}$ ions.

TRPC (canonical) family

Members of the TRPC subfamily (reviewed by [261, 726, 15, 4, 84, 410, 687, 60]) fall into the subgroups outlined below. TRPC2 is a pseudogene in humans. It is generally accepted that all TRPC channels are activated downstream of $\mathrm{G}_{\mathrm{q} / 11}$-coupled receptors, or receptor tyrosine kinases (reviewed by [713, 887, 997]). A comprehensive listing of G-protein coupled receptors that activate TRPC channels is given in [4]. Hetero-oligomeric complexes of TRPC channels and their association with proteins to form signalling complexes are detailed in [15] and [411]. TRPC channels have frequently been proposed to act as store-operated channels (SOCs) (or compenents of mulimeric complexes that form SOCs), activated by depletion of intracellular calcium stores (reviewed by [689, $15,718,764,1037,141,675,55,142])$. However, the weight of the evidence is that they are not directly gated by conventional store-operated mechanisms, as established for Stim-gated Orai channels. TRPC channels are not mechanically gated in physiologically relevant ranges of force. All members of the TRPC family are blocked by 2-APB and SKF96365 [319, 318]. Activation of TRPC channels by lipids is discussed by [60]. Important progress has been recently made in TRPC pharmacology [751, 571, 400, 92]. TRPC channels regulate a variety of physiological functions and are implicated in many human diseases [270, 61, 825, 958].

\section{TRPC1/C4/C5 subgroup}

TRPC1 alone may not form a functional ion channel [210]. TRPC4/C5 may be distinguished from other TRP channels by their potentiation by micromolar concentrations of $\mathrm{La}^{3+}$. TRPC2 is a pseudogene in humans, but in other mammals appears to be an ion channel localized to microvilli of the vomeronasal organ. It is required for normal sexual behavior in response to pheromones in mice. It may also function in the main olfactory epithelia in mice $[1034,672,673,1035,496,1075,1030]$.

\section{TRPC3/C6/C7 subgroup}

All members are activated by diacylglycerol independent of protein kinase C stimulation [319].

TRPM (melastatin) family

Members of the TRPM subfamily (reviewed by [252, 318, 689, 1062]) fall into the five subgroups outlined below.

\section{TRPM1/M3 subgroup}

In darkness, glutamate released by the photoreceptors and ON-bipolar cells binds to the metabotropic glutamate receptor 6 , leading to activation of Go. This results in the closure of TRPM1. When the photoreceptors are stimulated by light, glutamate release is reduced, and TRPM1 channels are more active, resulting in cell membrane depolarization. Human TRPM1 mutations are associated with congenital stationary night blindness (CSNB), whose patients lack rod function. TRPM1 is also found melanocytes. Isoforms of TRPM1 may present in melanocytes, melanoma, brain, and retina. In melanoma cells, TRPM1 is prevalent in highly dynamic intracellular vesicular structures [368, 657]. TRPM3 (reviewed by [663]) exists as multiple splice variants which differ significantly in their biophysical properties. TRPM3 is expressed in somatosensory neurons and may be important in development of heat hyperalgesia during inflammation (see review [876]). TRPM3 is frequently coexpressed with TRPA1 and TRPV1 in these neurons. TRPM3 is expressed in pancreatic beta cells as well as brain, pituitary gland, eye, kidney, and adipose tissue [662, 875]. TRPM3 may contribute to the detection of noxious heat [947].

\section{TRPM2}

TRPM2 is activated under conditions of oxidative stress (respiratory burst of phagocytic cells) and ischemic conditions. However, the direct activators are ADPR(P) and calcium. As for many ion channels, $\mathrm{PIP}_{2}$ must also be present (reviewed by [1018]). Numerous splice variants of TRPM2 exist which differ in their activation mechanisms [219]. The C-terminal domain contains a TRP motif, a coiled-coil region, and an enzymatic NUDT9 homologous domain. TRPM2 appears not to be activated by NAD, NAAD, or NAADP, but is directly activated by ADPRP (adenosine-5'-O-disphosphoribose phosphate) [900]. TRPM2 is involved in warmth sensation [788], and contributes to neurological 
diseases [66]. Recent study shows that 2'-deoxy-ADPR is an endogenous TRPM2 superagonist [253].

\section{TRPM4/5 subgroup}

TRPM4 and TRPM5 have the distinction within all TRP channels of being impermeable to $\mathrm{Ca}^{2+}$ [997]. A splice variant of TRPM4 (i.e.TRPM4b) and TRPM5 are molecular candidates for endogenous calcium-activated cation (CAN) channels [301]. TRPM4 is active in the late phase of repolarization of the cardiac ventricular action potential. TRPM4 deletion or knockout enhances beta adrenergicmediated inotropy [546]. Mutations are associated with conduction defects [374, 546, 819]. TRPM4 has been shown to be an important regulator of $\mathrm{Ca}^{2+}$ entry in to mast cells [924] and dendritic cell migration [43]. TRPM5 in taste receptor cells of the tongue appears essential for the transduction of sweet, amino acid and bitter stimuli [494] TRPM5 contributes to the slow afterdepolarization of layer 5 neurons in mouse prefrontal cortex [471]. Both TRPM4 and TRPM5 are required transduction of taste stimuli [226].

\section{TRPM6/7 subgroup}

TRPM6 and 7 combine channel and enzymatic activities ('chanzymes'). These channels have the unusual property of permeation by divalent $\left(\mathrm{Ca}^{2+}, \mathrm{Mg}^{2+}, \mathrm{Zn}^{2+}\right)$ and monovalent cations, high single channel conductances, but overall extremely small inward conductance when expressed to the plasma membrane. They are inhibited by internal $\mathrm{Mg}^{2+}$ at $\sim 0.6 \mathrm{mM}$, around the free level of $\mathrm{Mg}^{2+}$ in cells. Whether they contribute to $\mathrm{Mg}^{2+}$ homeostasis is a contentious issue. When either gene is deleted in mice, the result is embryonic lethality. The C-terminal kinase region is cleaved under unknown stimuli, and the kinase phosphorylates nuclear histones. TRPM7 is responsible for oxidantinduced $\mathrm{Zn}^{2+}$ release from intracellular vesicles [3] and contributes to intestinal mineral absorption essential for postnatal survival [574].

\section{TRPM8}

Is a channel activated by cooling and pharmacological agents evoking a 'cool' sensation and participates in the thermosensation of cold temperatures $[54,161,205]$ reviewed by $[941,516,420$, 599].

TRPML (mucolipin) family

The TRPML family [729, 1047, 723, 1008, 173] consists of three mammalian members (TRPML1-3). TRPML channels are probably restricted to intracellular vesicles and mutations in the gene (MCOLN1) encoding TRPML1 (mucolipin-1) cause the neurodegenerative disorder mucolipidosis type IV (MLIV) in man. TRPML1 is a cation selective ion channel that is important for sorting/transport of endosomes in the late endocytotic pathway and specifically, fission from late endosome-lysosome hybrid vesicles and lysosomal exocytosis [765]. TRPML2 and TRPML3 show increased channel activity in low extracellular sodium and are activated by similar small molecules [293]. A naturally occurring gain of function mutation in TRPML3 (i.e. A419P) results in the varitint waddler (Va) mouse phenotype (reviewed by [729, 639]).

TRPP (polycystin) family

The TRPP family (reviewed by [197, 195, 275, 986, 345]) or PKD2 family is comprised of PKD2 (PC2), PKD2L1 (PC2L1), PKD2L2 (PC2L2), which have been renamed TRPP1, TRPP2 and TRPP3, respectively [997]. It should also be noted that the nomenclature of PC2 was TRPP2 in old literature. However, PC2 has been uniformed to be called TRPP2 [317]. PKD2 family channels are clearly distinct from the PKD1 family, whose function is unknown. PKD1 and PKD2 form a hetero-oligomeric complex with a 1:3 ratio. [843]. Although still being sorted out, TRPP family members appear to be 6TM spanning nonselective cation channels.

TRPV (vanilloid) family

Members of the TRPV family (reviewed by [926]) can broadly be divided into the non-selective cation channels, TRPV1-4 and the more calcium selective channels TRPV5 and TRPV6.

\section{TRPV1-V4 subfamily}

TRPV1 is involved in the development of thermal hyperalgesia following inflammation and may contribute to the detection of noxius heat (reviewed by [710, 822, 858]). Numerous splice variants of TRPV1 have been described, some of which modulate the activity of TRPV1, or act in a dominant negative manner when co-expressed with TRPV1 [786]. The pharmacology of TRPV1 channels is discussed in detail in [303] and [945]. TRPV2 is probably not a thermosensor in man [684], but has recently been implicated in innate immunity [503]. TRPV3 and TRPV4 are both thermosensitive. There are claims that TRPV4 is also mechanosensitive, but this has not been established to be within a physiological range in a native environment $[114,488]$. 


\section{TRPV5/V6 subfamily}

TRPV5 and TRPV6 are highly expressed in placenta, bone, and kidney. Under physiological conditions, TRPV5 and TRPV6 are calcium selective channels involved in the absorption and reabsorption of calcium across intestinal and kidney tubule epithelia (reviewed by [982, 185, 601, 248]).

\section{Contents}

This is a citation summary for Transient Receptor Potential channels (TRP) in the Guide to Pharmacology database (GtoPdb). It exists purely as an adjunct to the database to facilitate the recognition of citations to and from the database by citation analyzers. Readers will almost certainly want to visit the relevant sections of the database which are given here under database links.

GtoPdb is an expert-driven guide to pharmacological targets and the substances that act on them. GtoPdb is a reference work which is most usefully represented as an on-line database. As in any publication this work should be appropriately cited, and the papers it cites should also be recognized. This document provides a citation for the relevant parts of the database, and also provides a reference list for the research cited by those parts. For further details see [108].

Please note that the database version for the citations given in GtoPdb are to the most recent preceding version in which the family or its subfamilies and targets were substantially changed. The links below are to the current version. If you need to consult the cited version, rather than the most recent version, please contact the GtoPdb curators.

\section{Database links}

Transient Receptor Potential channels (TRP)

https://www.guidetopharmacology.org/GRAC/FamilyDisplayForward?familyId=78

Introduction to Transient Receptor Potential channels (TRP)

https://www.guidetopharmacology.org/GRAC/FamilyIntroductionForward?familyId=78

Channels and Subunits

\section{TRPA1}

https://www.guidetopharmacology.org/GRAC/ObjectDisplayForward?objectId=485

TRPC1

https://www.guidetopharmacology.org/GRAC/ObjectDisplayForward?objectId=486

TRPC2

https://www.guidetopharmacology.org/GRAC/ObjectDisplayForward?objectId=487 TRPC3

https://www.guidetopharmacology.org/GRAC/ObjectDisplayForward?objectId=488 TRPC4

https://www.guidetopharmacology.org/GRAC/ObjectDisplayForward?objectId=489 TRPC5

https://www.guidetopharmacology.org/GRAC/ObjectDisplayForward?objectId=490 TRPC6

https://www.guidetopharmacology.org/GRAC/ObjectDisplayForward?objectId=491 TRPC7

https://www.guidetopharmacology.org/GRAC/ObjectDisplayForward?objectId=492 TRPM1

https://www.guidetopharmacology.org/GRAC/ObjectDisplayForward?objectId=493 TRPM2

https://www.guidetopharmacology.org/GRAC/ObjectDisplayForward?objectId=494 TRPM3

https://www.guidetopharmacology.org/GRAC/ObjectDisplayForward?objectId=495 TRPM4

https://www.guidetopharmacology.org/GRAC/ObjectDisplayForward?objectId=496 TRPM5

https://www.guidetopharmacology.org/GRAC/ObjectDisplayForward?objectId=497 TRPM6

https://www.guidetopharmacology.org/GRAC/ObjectDisplayForward?objectId=498 TRPM7

https://www.guidetopharmacology.org/GRAC/ObjectDisplayForward?objectId=499 TRPM8

https://www.guidetopharmacology.org/GRAC/ObjectDisplayForward?objectId=500 TRPML1

https://www.guidetopharmacology.org/GRAC/ObjectDisplayForward?objectId=501 


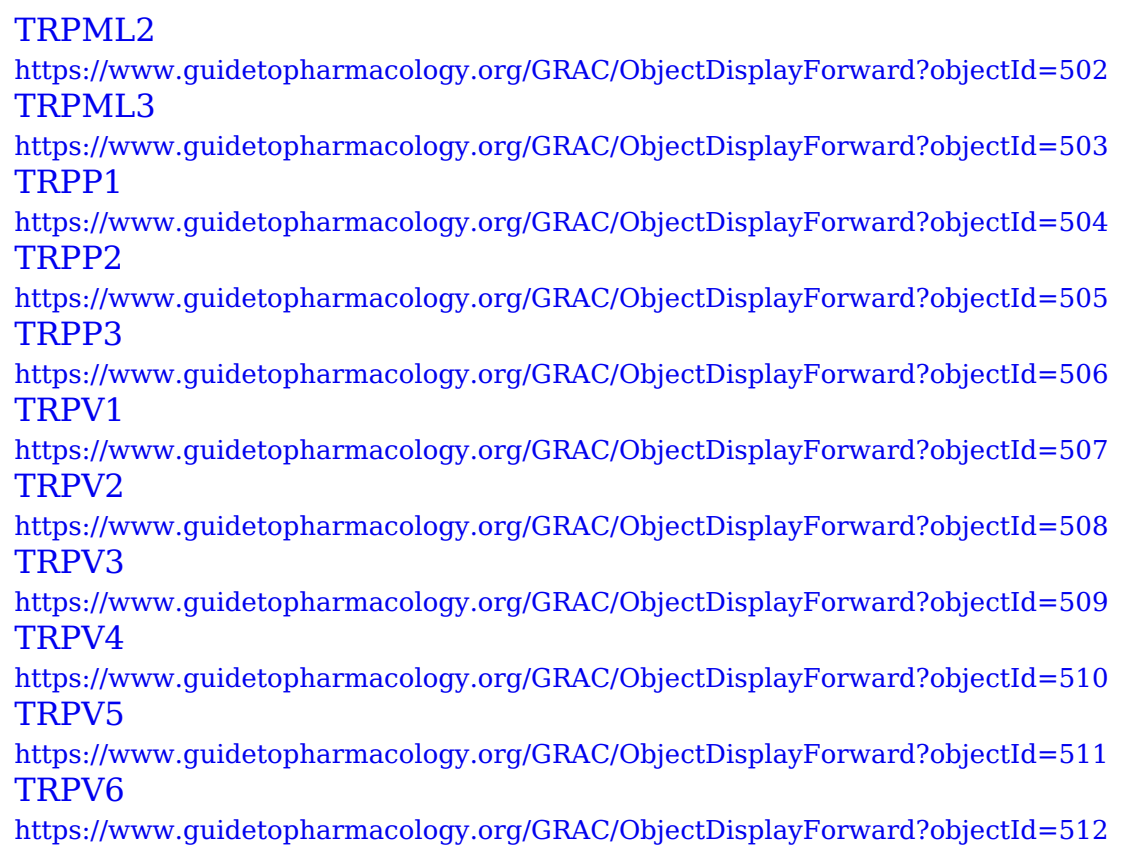

\section{References}

1. Aarts M, Iihara K, Wei WL, Xiong ZG, Arundine M, Cerwinski W, MacDonald JF and Tymianski M. (2003) A key role for TRPM7 channels in anoxic neuronal death. Cell 115: 863-77 [PMID:14697204]

2. Aarts MM and Tymianski M. (2005) TRPMs and neuronal cell death. Pflugers Arch 451: 243-9 [PMID:16044308]

3. Abiria SA, Krapivinsky G, Sah R, Santa-Cruz AG, Chaudhuri D, Zhang J, Adstamongkonkul P, DeCaen PG and Clapham DE. (2017) TRPM7 senses oxidative stress to release $\mathrm{Zn}^{2+}$ from unique intracellular vesicles. Proc Natl Acad Sci USA 114: E6079-E6088 [PMID:28696294]

4. Abramowitz J and Birnbaumer L. (2009) Physiology and pathophysiology of canonical transient receptor potential channels. FASEB J 23: 297-328 [PMID:18940894]

5. Adebiyi A, Zhao G, Narayanan D, Thomas-Gatewood CM, Bannister JP and Jaggar JH. (2010) Isoform-selective physical coupling of TRPC3 channels to IP3 receptors in smooth muscle cells regulates arterial contractility. Circ Res 106: 1603-12 [PMID:20378853]

6. Ahern GP. (2003) Activation of TRPV1 by the satiety factor oleoylethanolamide. J Biol Chem 278: 30429-34 [PMID:12761211]

7. Ahmed MK, Takumida M, Ishibashi T, Hamamoto T and Hirakawa K. (2009) Expression of transient receptor potential vanilloid (TRPV) families 1, 2, 3 and 4 in the mouse olfactory epithelium. Rhinology 47: 242-7 [PMID:19839244]

8. Akbulut Y, Gaunt HJ, Muraki K, Ludlow MJ, Amer MS, Bruns A, Vasudev NS, Radtke L, Willot M and Hahn S et al.. (2015) (-)-Englerin A is a potent and selective activator of TRPC4 and TRPC5 calcium channels. Angew Chem Int Ed Engl 54: 3787-91 [PMID:25707820]

9. Akopian AN, Ruparel NB, Patwardhan A and Hargreaves KM. (2008) Cannabinoids desensitize capsaicin and mustard oil responses in sensory neurons via TRPA1 activation. J Neurosci $\mathbf{2 8}$ : 1064-75 [PMID:18234885]

10. Alessandri-Haber N, Dina OA, Joseph EK, Reichling D and Levine JD. (2006) A transient receptor potential vanilloid 4-dependent mechanism of hyperalgesia is engaged by concerted action of inflammatory mediators. J Neurosci 26: 3864-74 [PMID:16597741]

11. Alessandri-Haber N, Yeh JJ, Boyd AE, Parada CA, Chen X, Reichling DB and Levine JD. (2003) Hypotonicity induces TRPV4-mediated nociception in rat. Neuron 39: 497-511 [PMID:12895423]

12. Alfonso S, Benito O, Alicia S, Angélica Z, Patricia G, Diana K, Vaca L and Luis V. (2008) Regulation of the cellular localization and function of human transient receptor potential channel 1 by other members of the TRPC family. Cell Calcium 43: 375-87 [PMID:17850866]

13. Almeida MC, Hew-Butler T, Soriano RN, Rao S, Wang W, Wang J, Tamayo N, Oliveira DL, Nucci TB and Aryal P et al.. (2012) Pharmacological blockade of the cold receptor TRPM8 attenuates autonomic and behavioral cold defenses and decreases deep body temperature. J Neurosci 32: 2086-99 [PMID:22323721]

14. Alvarez DF, King JA, Weber D, Addison E, Liedtke W and Townsley MI. (2006) Transient receptor potential vanilloid 4-mediated disruption of the alveolar septal barrier: a novel mechanism of acute lung injury. Circ Res 99: 988-95 [PMID:17008604]

15. Ambudkar IS and Ong HL. (2007) Organization and function of TRPC channelosomes. Pflugers 
Arch 455: 187-200 [PMID:17486362]

16. Ambudkar IS, Ong HL, Liu X, Bandyopadhyay BC, Bandyopadhyay B and Cheng KT. (2007) TRPC1: the link between functionally distinct store-operated calcium channels. Cell Calcium 42: 213-23 [PMID:17350680]

17. Andersson DA, Chase HW and Bevan S. (2004) TRPM8 activation by menthol, icilin, and cold is differentially modulated by intracellular pH. J Neurosci 24: 5364-9 [PMID:15190109]

18. Andersson DA, Gentry C, Alenmyr L, Killander D, Lewis SE, Andersson A, Bucher B, Galzi JL, Sterner O and Bevan S et al.. (2011) TRPA1 mediates spinal antinociception induced by acetaminophen and the cannabinoid $\Delta(9)$-tetrahydrocannabiorcol. Nat Commun 2: 551 [PMID:22109525]

19. Andersson DA, Gentry C, Moss S and Bevan S. (2009) Clioquinol and pyrithione activate TRPA1 by increasing intracellular Zn2+. Proc Natl Acad Sci USA 106: 8374-9 [PMID:19416844]

20. Andersson DA, Gentry C, Moss S and Bevan S. (2008) Transient receptor potential A1 is a sensory receptor for multiple products of oxidative stress. J Neurosci 28: 2485-94 [PMID:18322093]

21. Andrade EL, Forner S, Bento AF, Leite DF, Dias MA, Leal PC, Koepp J and Calixto JB. (2011) TRPA1 receptor modulation attenuates bladder overactivity induced by spinal cord injury. Am J Physiol Renal Physiol 300: F1223-34 [PMID:21367919]

22. Andrews MD, Af Forselles K, Beaumont K, Galan SR, Glossop PA, Grenie M, Jessiman A, Kenyon AS, Lunn G and Maw G et al.. (2015) Discovery of a Selective TRPM8 Antagonist with Clinical Efficacy in Cold-Related Pain. ACS Med Chem Lett 6: 419-24 [PMID:25893043]

23. Andrè E, Campi B, Materazzi S, Trevisani M, Amadesi S, Massi D, Creminon C, Vaksman N, Nassini R and Civelli M et al.. (2008) Cigarette smoke-induced neurogenic inflammation is mediated by alpha,beta-unsaturated aldehydes and the TRPA1 receptor in rodents. J Clin Invest 118: 2574-82 [PMID:18568077]

24. Andrè E, Gatti R, Trevisani M, Preti D, Baraldi PG, Patacchini R and Geppetti P. (2009) Transient receptor potential ankyrin receptor 1 is a novel target for pro-tussive agents. $\mathrm{BrJ}$ Pharmacol 158: 1621-8 [PMID:19845671]

25. Ann J, Kim HS, Thorat SA, Kim H, Ha HJ, Choi K, Kim YH, Kim M, Hwang SW and Pearce LV et al.. (2020) Discovery of Nonpungent Transient Receptor Potential Vanilloid 1 (TRPV1) Agonist as Strong Topical Analgesic. J Med Chem 63: 418-424 [PMID:31702924]

26. Aoyagi K, Ohara-Imaizumi M, Nishiwaki C, Nakamichi Y and Nagamatsu S. (2010) Insulin/phosphoinositide 3-kinase pathway accelerates the glucose-induced first-phase insulin secretion through TrpV2 recruitment in pancreatic $\beta$-cells. Biochem J 432: 375-86 [PMID:20854263]

27. Appendino G, De Petrocellis L, Trevisani M, Minassi A, Daddario N, Moriello AS, Gazzieri D, Ligresti A, Campi B and Fontana G et al.. (2005) Development of the first ultra-potent "capsaicinoid" agonist at transient receptor potential vanilloid type 1 (TRPV1) channels and its therapeutic potential. J Pharmacol Exp Ther 312: 561-70 [PMID:15356216]

28. Asakawa M, Yoshioka T, Matsutani T, Hikita I, Suzuki M, Oshima I, Tsukahara K, Arimura A, Horikawa T and Hirasawa T et al.. (2006) Association of a mutation in TRPV3 with defective hair growth in rodents. J Invest Dermatol 126: 2664-72 [PMID:16858425]

29. Assas BM, Wakid MH, Zakai HA, Miyan JA and Pennock JL. (2016) Transient receptor potential vanilloid 1 expression and function in splenic dendritic cells: a potential role in immune homeostasis. Immunology 147: 292-304 [PMID:26643862]

30. Audo I, Kohl S, Leroy BP, Munier FL, Guillonneau X, Mohand-Saïd S, Bujakowska K, Nandrot EF, Lorenz B and Preising M et al.. (2009) TRPM1 is mutated in patients with autosomalrecessive complete congenital stationary night blindness. Am J Hum Genet 85: 720-9 [PMID:19896113]

31. Auer-Grumbach M, Olschewski A, Papić L, Kremer H, McEntagart ME, Uhrig S, Fischer C, Fröhlich E, Bálint Z and Tang B et al.. (2010) Alterations in the ankyrin domain of TRPV4 cause congenital distal SMA, scapuloperoneal SMA and HMSN2C. Nat Genet 42: 160-4 [PMID:20037588]

32. Badheka D, Yudin Y, Borbiro I, Hartle CM, Yazici A, Mirshahi T and Rohacs T. (2017) Inhibition of Transient Receptor Potential Melastatin 3 ion channels by G-protein $\beta \gamma$ subunits. Elife $\mathbf{6}$ [PMID:28829742]

33. Balzer M, Lintschinger B and Groschner K. (1999) Evidence for a role of Trp proteins in the oxidative stress-induced membrane conductances of porcine aortic endothelial cells. Cardiovasc Res 42: 543-9 [PMID:10533589]

34. Bandell M, Story GM, Hwang SW, Viswanath V, Eid SR, Petrus MJ, Earley TJ and Patapoutian A. (2004) Noxious cold ion channel TRPA1 is activated by pungent compounds and bradykinin. Neuron 41: 849-57 [PMID:15046718]

35. Bandyopadhyay BC, Swaim WD, Liu X, Redman RS, Patterson RL and Ambudkar IS. (2005) Apical localization of a functional TRPC3/TRPC6-Ca2+-signaling complex in polarized epithelial cells. Role in apical Ca2+ influx. J Biol Chem 280: 12908-16 [PMID:15623527] 
36. Bang S, Kim KY, Yoo S, Kim YG and Hwang SW. (2007) Transient receptor potential A1 mediates acetaldehyde-evoked pain sensation. Eur J Neurosci 26: 2516-23 [PMID:17970723]

37. Bang S, Kim KY, Yoo S, Lee SH and Hwang SW. (2007) Transient receptor potential V2 expressed in sensory neurons is activated by probenecid. Neurosci Lett 425: 120-5 [PMID:17850966]

38. Bang S, Yoo S, Yang TJ, Cho H and Hwang SW. (2012) 17(R)-resolvin D1 specifically inhibits transient receptor potential ion channel vanilloid 3 leading to peripheral antinociception. $B r J$ Pharmacol 165: 683-92 [PMID:21718307]

39. Bang S, Yoo S, Yang TJ, Cho H and Hwang SW. (2011) Isopentenyl pyrophosphate is a novel antinociceptive substance that inhibits TRPV3 and TRPA1 ion channels. Pain 152: 1156-64 [PMID:21353389]

40. Bang S, Yoo S, Yang TJ, Cho H and Hwang SW. (2010) Farnesyl pyrophosphate is a novel painproducing molecule via specific activation of TRPV3. J Biol Chem 285: 19362-71 [PMID:20395302]

41. Bang S, Yoo S, Yang TJ, Cho H, Kim YG and Hwang SW. (2010) Resolvin D1 attenuates activation of sensory transient receptor potential channels leading to multiple anti-nociception. Br J Pharmacol 161: 707-20 [PMID:20880407]

42. Baraldi PG, Preti D, Materazzi S and Geppetti P. (2010) Transient receptor potential ankyrin 1 (TRPA1) channel as emerging target for novel analgesics and anti-inflammatory agents. J Med Chem 53: 5085-107 [PMID:20356305]

43. Barbet G, Demion M, Moura IC, Serafini N, Léger T, Vrtovsnik F, Monteiro RC, Guinamard R, Kinet JP and Launay P. (2008) The calcium-activated nonselective cation channel TRPM4 is essential for the migration but not the maturation of dendritic cells. Nat Immunol 9: 1148-56 [PMID:18758465]

44. Bargal R, Avidan N, Ben-Asher E, Olender Z, Zeigler M, Frumkin A, Raas-Rothschild A, Glusman G, Lancet D and Bach G. (2000) Identification of the gene causing mucolipidosis type IV. Nat Genet 26: 118-23 [PMID:10973263]

45. Bargal R and Bach G. (1997) Mucolipidosis type IV: abnormal transport of lipids to lysosomes. $J$ Inherit Metab Dis 20: 625-32 [PMID:9323557]

46. Bari MR, Akbar S, Eweida M, Kühn FJ, Gustafsson AJ, Lückhoff A and Islam MS. (2009) H2O2induced $\mathrm{Ca} 2+$ influx and its inhibition by N-(p-amylcinnamoyl) anthranilic acid in the beta-cells: involvement of TRPM2 channels. J Cell Mol Med 13: 3260-7 [PMID:19382906]

47. Barley NF, Howard A, O'Callaghan D, Legon S and Walters JR. (2001) Epithelial calcium transporter expression in human duodenum. Am J Physiol Gastrointest Liver Physiol 280: G28590 [PMID:11208552]

48. Barnhill JC, Stokes AJ, Koblan-Huberson M, Shimoda LM, Muraguchi A, Adra CN and Turner H. (2004) RGA protein associates with a TRPV ion channel during biosynthesis and trafficking. $J$ Cell Biochem 91: 808-20 [PMID:14991772]

49. Barrière DA, Rieusset J, Chanteranne D, Busserolles J, Chauvin MA, Chapuis L, Salles J, Dubray C and Morio B. (2012) Paclitaxel therapy potentiates cold hyperalgesia in streptozotocininduced diabetic rats through enhanced mitochondrial reactive oxygen species production and TRPA1 sensitization. Pain 153: 553-61 [PMID:22177224]

50. Barro-Soria R, Stindl J, Müller C, Foeckler R, Todorov V, Castrop H and Strauß O. (2012) Angiotensin-2-mediated Ca2 + signaling in the retinal pigment epithelium: role of angiotensinreceptor-associated-protein and TRPV2 channel. PLoS ONE 7: e49624 [PMID:23185387]

51. Bautista DM, Jordt SE, Nikai T, Tsuruda PR, Read AJ, Poblete J, Yamoah EN, Basbaum AI and Julius D. (2006) TRPA1 mediates the inflammatory actions of environmental irritants and proalgesic agents. Cell 124: 1269-82 [PMID:16564016]

52. Bautista DM, Movahed P, Hinman A, Axelsson HE, Sterner O, Högestätt ED, Julius D, Jordt SE and Zygmunt PM. (2005) Pungent products from garlic activate the sensory ion channel TRPA1. Proc Natl Acad Sci USA 102: 12248-52 [PMID:16103371]

53. Bautista DM, Pellegrino M and Tsunozaki M. (2013) TRPA1: A gatekeeper for inflammation. Annu Rev Physiol 75: 181-200 [PMID:23020579]

54. Bautista DM, Siemens J, Glazer JM, Tsuruda PR, Basbaum AI, Stucky CL, Jordt SE and Julius D. (2007) The menthol receptor TRPM8 is the principal detector of environmental cold. Nature 448: 204-8 [PMID:17538622]

55. Bavencoffe A, Zhu MX and Tian JB. (2017) New Aspects of the Contribution of ER to SOCE Regulation: TRPC Proteins as a Link Between Plasma Membrane Ion Transport and Intracellular $\mathrm{Ca}^{2+}$ Stores. Adv Exp Med Biol 993: 239-255 [PMID:28900918]

56. Becerra A, Echeverría C, Varela D, Sarmiento D, Armisén R, Nuñez-Villena F, Montecinos M and Simon F. (2011) Transient receptor potential melastatin 4 inhibition prevents lipopolysaccharide-induced endothelial cell death. Cardiovasc Res 91: 677-84 [PMID:21565835]

57. Beck A, Kolisek M, Bagley LA, Fleig A and Penner R. (2006) Nicotinic acid adenine dinucleotide phosphate and cyclic ADP-ribose regulate TRPM2 channels in T lymphocytes. FASEB J 20: 962-4 [PMID:16585058] 
58. Becker EB, Oliver PL, Glitsch MD, Banks GT, Achilli F, Hardy A, Nolan PM, Fisher EM and Davies KE. (2009) A point mutation in TRPC3 causes abnormal Purkinje cell development and cerebellar ataxia in moonwalker mice. Proc Natl Acad Sci USA 106: 6706-11 [PMID:19351902]

59. Beckmann H, Richter J, Hill K, Urban N, Lemoine H and Schaefer M. (2017) A benzothiadiazine derivative and methylprednisolone are novel and selective activators of transient receptor potential canonical 5 (TRPC5) channels. Cell Calcium 66: 10-18 [PMID:28807145]

60. Beech DJ. (2012) Integration of transient receptor potential canonical channels with lipids. Acta Physiol (Oxf) 204: 227-37 [PMID:21624095]

61. Beech DJ. (2013) Characteristics of transient receptor potential canonical calcium-permeable channels and their relevance to vascular physiology and disease. Circ J 77: 570-9 [PMID:23412755]

62. Behrendt HJ, Germann T, Gillen C, Hatt H and Jostock R. (2004) Characterization of the mouse cold-menthol receptor TRPM8 and vanilloid receptor type-1 VR1 using a fluorometric imaging plate reader (FLIPR) assay. Br J Pharmacol 141: 737-45 [PMID:14757700]

63. Beis D, Schwarting RK and Dietrich A. (2011) Evidence for a supportive role of classical transient receptor potential 6 (TRPC6) in the exploration behavior of mice. Physiol Behav 102: 245-50 [PMID:21059368]

64. Bellone RR, Forsyth G, Leeb T, Archer S, Sigurdsson S, Imsland F, Mauceli E, Engensteiner M, Bailey E and Sandmeyer L et al.. (2010) Fine-mapping and mutation analysis of TRPM1: a candidate gene for leopard complex (LP) spotting and congenital stationary night blindness in horses. Brief Functional Genomics 9: 193-207 [PMID:20353955]

65. Bellono NW, Kammel LG, Zimmerman AL and Oancea E. (2013) UV light phototransduction activates transient receptor potential A1 ion channels in human melanocytes. Proc Natl Acad Sci USA 110: 2383-8 [PMID:23345429]

66. Belrose JC and Jackson MF. (2018) TRPM2: a candidate therapeutic target for treating neurological diseases. Acta Pharmacol Sin 39: 722-732 [PMID:29671419]

67. Belrose JC, Xie YF, Gierszewski LJ, MacDonald JF and Jackson MF. (2012) Loss of glutathione homeostasis associated with neuronal senescence facilitates TRPM2 channel activation in cultured hippocampal pyramidal neurons. Mol Brain 5: 11 [PMID:22487454]

68. Benfenati V, Amiry-Moghaddam M, Caprini M, Mylonakou MN, Rapisarda C, Ottersen OP and Ferroni S. (2007) Expression and functional characterization of transient receptor potential vanilloid-related channel 4 (TRPV4) in rat cortical astrocytes. Neuroscience 148: 876-92 [PMID:17719182]

69. Berbey C, Weiss N, Legrand C and Allard B. (2009) Transient receptor potential canonical type 1 (TRPC1) operates as a sarcoplasmic reticulum calcium leak channel in skeletal muscle. J Biol Chem 284: 36387-94 [PMID:19875453]

70. Bertin S, Aoki-Nonaka Y, de Jong PR, Nohara LL, Xu H, Stanwood SR, Srikanth S, Lee J, To K and Abramson L et al.. (2014) The ion channel TRPV1 regulates the activation and proinflammatory properties of CD4+ T cells. Nat Immunol 15: 1055-1063 [PMID:25282159]

71. Bertin S, de Jong PR, Jefferies WA and Raz E. (2014) Novel immune function for the TRPV1 channel in T lymphocytes. Channels (Austin) 8: 479-80 [PMID:25530461]

72. Bessac BF and Jordt SE. (2010) Sensory detection and responses to toxic gases: mechanisms, health effects, and countermeasures. Proc Am Thorac Soc 7: 269-77 [PMID:20601631]

73. Bessac BF, Sivula M, von Hehn CA, Caceres AI, Escalera J and Jordt SE. (2009) Transient receptor potential ankyrin 1 antagonists block the noxious effects of toxic industrial isocyanates and tear gases. FASEB J 23: 1102-14 [PMID:19036859]

74. Bessac BF, Sivula M, von Hehn CA, Escalera J, Cohn L and Jordt SE. (2008) TRPA1 is a major oxidant sensor in murine airway sensory neurons. J Clin Invest 118: 1899-910 [PMID:18398506]

75. Bezençon C, le Coutre J and Damak S. (2007) Taste-signaling proteins are coexpressed in solitary intestinal epithelial cells. Chem Senses 32: 41-9 [PMID:17030556]

76. Bhave G, Hu HJ, Glauner KS, Zhu W, Wang H, Brasier DJ, Oxford GS and Gereau 4th RW. (2003) Protein kinase $\mathrm{C}$ phosphorylation sensitizes but does not activate the capsaicin receptor transient receptor potential vanilloid 1 (TRPV1). Proc Natl Acad Sci USA 100: 12480-5 [PMID:14523239]

77. Bhunia AK, Piontek K, Boletta A, Liu L, Qian F, Xu PN, Germino FJ and Germino GG. (2002) PKD1 induces p21(waf1) and regulation of the cell cycle via direct activation of the JAK-STAT signaling pathway in a process requiring PKD2. Cell 109: 157-68 [PMID:12007403]

78. Bianchi B, Smith PA and Abriel H. (2018) The ion channel TRPM4 in murine experimental autoimmune encephalomyelitis and in a model of glutamate-induced neuronal degeneration. Mol Brain 11: 41 [PMID:29996905]

79. Bianchi BR, El Kouhen R, Neelands TR, Lee CH, Gomtsyan A, Raja SN, Vaidyanathan SN, Surber B, McDonald HA and Surowy CS et al.. (2007) [3H]A-778317 [1-((R)-5-tert-butyl-indan-1-yl)-3isoquinolin-5-yl-urea]: a novel, stereoselective, high-affinity antagonist is a useful radioligand for the human transient receptor potential vanilloid-1 (TRPV1) receptor. J Pharmacol Exp Ther 323 : 285-93 [PMID:17660385] 
80. Bianco SD, Peng JB, Takanaga H, Suzuki Y, Crescenzi A, Kos CH, Zhuang L, Freeman MR, Gouveia $\mathrm{CH}$ and Wu J et al.. (2007) Marked disturbance of calcium homeostasis in mice with targeted disruption of the Trpv6 calcium channel gene. J Bone Miner Res 22: 274-85 [PMID:17129178]

81. Binder A, May D, Baron R, Maier C, Tölle TR, Treede RD, Berthele A, Faltraco F, Flor H and Gierthmühlen J et al.. (2011) Transient receptor potential channel polymorphisms are associated with the somatosensory function in neuropathic pain patients. PLOS ONE 6: e17387 [PMID:21468319]

82. Birder L, Kullmann FA, Lee H, Barrick S, de Groat W, Kanai A and Caterina M. (2007) Activation of urothelial transient receptor potential vanilloid 4 by 4 alpha-phorbol 12,13-didecanoate contributes to altered bladder reflexes in the rat. J Pharmacol Exp Ther 323: 227-35 [PMID:17636010]

83. Birder LA, Kanai AJ, de Groat WC, Kiss S, Nealen ML, Burke NE, Dineley KE, Watkins S, Reynolds IJ and Caterina MJ. (2001) Vanilloid receptor expression suggests a sensory role for urinary bladder epithelial cells. Proc Natl Acad Sci USA 98: 13396-401 [PMID:11606761]

84. Birnbaumer L. (2009) The TRPC class of ion channels: a critical review of their roles in slow, sustained increases in intracellular $\mathrm{Ca}(2+)$ concentrations. Annu Rev Pharmacol Toxicol 49: 395-426 [PMID:19281310]

85. Birrell MA, Belvisi MG, Grace M, Sadofsky L, Faruqi S, Hele DJ, Maher SA, Freund-Michel V and Morice AH. (2009) TRPA1 agonists evoke coughing in guinea pig and human volunteers. Am $J$ Respir Crit Care Med 180: 1042-7 [PMID:19729665]

86. Blair NT, Kaczmarek JS and Clapham DE. (2009) Intracellular calcium strongly potentiates agonist-activated TRPC5 channels. J Gen Physiol 133: 525-46 [PMID:19398778]

87. Blum CA, Caldwell T, Zheng X, Bakthavatchalam R, Capitosti S, Brielmann H, De Lombaert S, Kershaw MT, Matson D and Krause JE et al.. (2010) Discovery of novel 6,6-heterocycles as transient receptor potential vanilloid (TRPV1) antagonists. J Med Chem 53: 3330-48 [PMID:20307063]

88. Boels K, Glassmeier G, Herrmann D, Riedel IB, Hampe W, Kojima I, Schwarz JR and Schaller HC. (2001) The neuropeptide head activator induces activation and translocation of the growthfactor-regulated Ca(2+)-permeable channel GRC. J Cell Sci 114: 3599-606 [PMID:11707512]

89. Bohlen CJ, Priel A, Zhou S, King D, Siemens J and Julius D. (2010) A bivalent tarantula toxin activates the capsaicin receptor, TRPV1, by targeting the outer pore domain. Cell 141: 834-45 [PMID:20510930]

90. Boisseau S, Kunert-Keil C, Lucke S and Bouron A. (2009) Heterogeneous distribution of TRPC proteins in the embryonic cortex. Histochem Cell Biol 131: 355-63 [PMID:18989690]

91. Bollimuntha S, Ebadi M and Singh BB. (2006) TRPC1 protects human SH-SY5Y cells against salsolinol-induced cytotoxicity by inhibiting apoptosis. Brain Res 1099: 141-9 [PMID:16765919]

92. Bon RS and Beech DJ. (2013) In pursuit of small molecule chemistry for calcium-permeable nonselective TRPC channels -- mirage or pot of gold? Br J Pharmacol 170: 459-74 [PMID:23763262]

93. Bonet IJ, Fischer L, Parada CA and Tambeli CH. (2013) The role of transient receptor potential A 1 (TRPA1) in the development and maintenance of carrageenan-induced hyperalgesia. Neuropharmacology 65: 206-12 [PMID:23098993]

94. Borbíró I, Lisztes E, Tóth BI, Czifra G, Oláh A, Szöllosi AG, Szentandrássy N, Nánási PP, Péter Z and Paus R et al.. (2011) Activation of transient receptor potential vanilloid-3 inhibits human hair growth. J Invest Dermatol 131: 1605-14 [PMID:21593771]

95. Bork P. (1993) Hundreds of ankyrin-like repeats in functionally diverse proteins: mobile modules that cross phyla horizontally? Proteins 17: 363-74 [PMID:8108379]

96. Boulay G. (2002) $\mathrm{Ca}(2+)$-calmodulin regulates receptor-operated $\mathrm{Ca}(2+)$ entry activity of TRPC6 in HEK-293 cells. Cell Calcium 32: 201-7 [PMID:12379180]

97. Boulay G, Zhu X, Peyton M, Jiang M, Hurst R, Stefani E and Birnbaumer L. (1997) Cloning and expression of a novel mammalian homolog of Drosophila transient receptor potential (Trp) involved in calcium entry secondary to activation of receptors coupled by the Gq class of G protein. J Biol Chem 272: 29672-80 [PMID:9368034]

98. Boulay ME and Boulet LP. (2002) Lower airway inflammatory responses to repeated very-lowdose allergen challenge in allergic rhinitis and asthma. Clin Exp Allergy 32: 1441-7 [PMID:12372123]

99. Bowen CV, DeBay D, Ewart HS, Gallant P, Gormley S, Ilenchuk TT, Iqbal U, Lutes T, Martina M and Mealing G et al.. (2013) In vivo detection of human TRPV6-rich tumors with anti-cancer peptides derived from soricidin. PLoS ONE 8: e58866 [PMID:23554944]

100. Brann JH, Dennis JC, Morrison EE and Fadool DA. (2002) Type-specific inositol 1,4,5trisphosphate receptor localization in the vomeronasal organ and its interaction with a transient receptor potential channel, TRPC2. J Neurochem 83: 1452-60 [PMID:12472899]

101. Brauchi S, Orio P and Latorre R. (2004) Clues to understanding cold sensation: thermodynamics and electrophysiological analysis of the cold receptor TRPM8. Proc Natl Acad Sci USA 101: 15494-9 [PMID:15492228] 
102. Brierley SM, Castro J, Harrington AM, Hughes PA, Page AJ, Rychkov GY and Blackshaw LA. (2011) TRPA1 contributes to specific mechanically activated currents and sensory neuron mechanical hypersensitivity. J Physiol (Lond.) 589: 3575-93 [PMID:21558163]

103. Brierley SM, Hughes PA, Page AJ, Kwan KY, Martin CM, O'Donnell TA, Cooper NJ, Harrington AM, Adam B and Liebregts T et al.. (2009) The ion channel TRPA1 is required for normal mechanosensation and is modulated by algesic stimuli. Gastroenterology 137: 2084-2095.e3 [PMID:19632231]

104. Brixel LR, Monteilh-Zoller MK, Ingenbrandt CS, Fleig A, Penner R, Enklaar T, Zabel BU and Prawitt D. (2010) TRPM5 regulates glucose-stimulated insulin secretion. Pflugers Arch 460: 6976 [PMID:20393858]

105. Broad LM, Mogg AJ, Eberle E, Tolley M, Li DL and Knopp KL. (2016) TRPV3 in Drug Development. Pharmaceuticals (Basel) 9 [PMID:27618069]

106. Broertjes J, Klarenbeek J, Habani Y, Langeslag M and Jalink K. (2019) TRPM7 residue S1269 mediates cAMP dependence of Ca2+ influx. PLoS ONE 14: e0209563 [PMID:30615643]

107. Brône B, Peeters PJ, Marrannes R, Mercken M, Nuydens R, Meert T and Gijsen HJ. (2008) Tear gasses CN, CR, and CS are potent activators of the human TRPA1 receptor. Toxicol Appl Pharmacol 231: 150-6 [PMID:18501939]

108. Buneman P, Christie G, Davies JA, Dimitrellou R, Harding SD, Pawson AJ, Sharman JL and Wu Y. (2020) Why data citation isn't working, and what to do about it Database 2020 [PMID:32367113]

109. Bíró T and Kovács L. (2009) An "ice-cold" TR(i)P to skin biology: the role of TRPA1 in human epidermal keratinocytes. J Invest Dermatol 129: 2096-9 [PMID:19809424]

110. Cabanas H, Muraki K, Eaton N, Balinas C, Staines D and Marshall-Gradisnik S. (2018) Loss of Transient Receptor Potential Melastatin 3 ion channel function in natural killer cells from Chronic Fatigue Syndrome/Myalgic Encephalomyelitis patients. Mol Med 24: 44 [PMID:30134818]

111. Caceres AI, Brackmann M, Elia MD, Bessac BF, del Camino D, D'Amours M, Witek JS, Fanger CM, Chong JA and Hayward NJ et al.. (2009) A sensory neuronal ion channel essential for airway inflammation and hyperreactivity in asthma. Proc Natl Acad Sci USA 106: 9099-104 [PMID:19458046]

112. Camacho N, Krakow D, Johnykutty S, Katzman PJ, Pepkowitz S, Vriens J, Nilius B, Boyce BF and Cohn DH. (2010) Dominant TRPV4 mutations in nonlethal and lethal metatropic dysplasia. Am J Med Genet A 152A: 1169-77 [PMID:20425821]

113. Cao DS, Zhong L, Hsieh TH, Abooj M, Bishnoi M, Hughes L and Premkumar LS. (2012) Expression of transient receptor potential ankyrin 1 (TRPA1) and its role in insulin release from rat pancreatic beta cells. PLoS ONE 7: e38005 [PMID:22701540]

114. Cao E, Liao M, Cheng Y and Julius D. (2013) TRPV1 structures in distinct conformations reveal activation mechanisms. Nature 504: 113-8 [PMID:24305161]

115. Cao Y, Posokhova E and Martemyanov KA. (2011) TRPM1 forms complexes with nyctalopin in vivo and accumulates in postsynaptic compartment of ON-bipolar neurons in mGluR6-dependent manner. J Neurosci 31: 11521-6 [PMID:21832182]

116. Carrasquillo R, Tian D, Krishna S, Pollak MR, Greka A and Schlöndorff J. (2012) SNF8, a member of the ESCRT-II complex, interacts with TRPC6 and enhances its channel activity. BMC Cell Biol 13: 33 [PMID:23171048]

117. Carstens E, Akiyama T, Wilson SR and Bautista DM. (2014) Role of Transient Receptor Potential Channels in Acute and Chronic Itch Itch: Mechanisms and Treatment [PMID:24830011]

118. Castiglioni AJ, Remis NN, Flores EN and García-Añoveros J. (2011) Expression and vesicular localization of mouse Trpml3 in stria vascularis, hair cells, and vomeronasal and olfactory receptor neurons. J Comp Neurol 519: 1095-114 [PMID:21344404]

119. Castillo B, Pörzgen P, Penner R, Horgen FD and Fleig A. (2010) Development and optimization of a high-throughput bioassay for TRPM7 ion channel inhibitors. J Biomol Screen 15: 498-507 [PMID:20413646]

120. Caterina MJ, Leffler A, Malmberg AB, Martin WJ, Trafton J, Petersen-Zeitz KR, Koltzenburg M, Basbaum AI and Julius D. (2000) Impaired nociception and pain sensation in mice lacking the capsaicin receptor. Science 288: 306-13 [PMID:10764638]

121. Caterina MJ, Rosen TA, Tominaga M, Brake AJ and Julius D. (1999) A capsaicin-receptor homologue with a high threshold for noxious heat. Nature 398: 436-41 [PMID:10201375]

122. Caterina MJ, Schumacher MA, Tominaga M, Rosen TA, Levine JD and Julius D. (1997) The capsaicin receptor: a heat-activated ion channel in the pain pathway. Nature 389: 816-24 [PMID:9349813]

123. Cattaruzza F, Spreadbury I, Miranda-Morales M, Grady EF, Vanner S and Bunnett NW. (2010) Transient receptor potential ankyrin-1 has a major role in mediating visceral pain in mice. Am J Physiol Gastrointest Liver Physiol 298: G81-91 [PMID:19875705]

124. Catterall WA. (2010) Ion channel voltage sensors: structure, function, and pathophysiology. Neuron 67: 915-28 [PMID:20869590] 
125. Cavanaugh DJ, Chesler AT, Bráz JM, Shah NM, Julius D and Basbaum AI. (2011) Restriction of transient receptor potential vanilloid-1 to the peptidergic subset of primary afferent neurons follows its developmental downregulation in nonpeptidergic neurons. J Neurosci 31: 10119-27 [PMID:21752988]

126. Cavanaugh DJ, Chesler AT, Jackson AC, Sigal YM, Yamanaka H, Grant R, O'Donnell D, Nicoll RA, Shah NM and Julius D et al.. (2011) Trpv1 reporter mice reveal highly restricted brain distribution and functional expression in arteriolar smooth muscle cells. J Neurosci 31: 5067-77 [PMID:21451044]

127. Ceppa E, Cattaruzza F, Lyo V, Amadesi S, Pelayo JC, Poole DP, Vaksman N, Liedtke W, Cohen DM and Grady EF et al.. (2010) Transient receptor potential ion channels V4 and A1 contribute to pancreatitis pain in mice. Am J Physiol Gastrointest Liver Physiol 299: G556-71 [PMID:20539005]

128. Chabardès-Garonne D, Mejéan A, Aude JC, Cheval L, Di Stefano A, Gaillard MC, Imbert-Teboul M, Wittner M, Balian C and Anthouard V et al.. (2003) A panoramic view of gene expression in the human kidney. Proc Natl Acad Sci USA 100: 13710-5 [PMID:14595018]

129. Chakraborty S, Berwick ZC, Bartlett PJ, Kumar S, Thomas AP, Sturek M, Tune JD and Obukhov AG. (2011) Bromoenol lactone inhibits voltage-gated Ca2+ and transient receptor potential canonical channels. J Pharmacol Exp Ther 339: 329-40 [PMID:21795434]

130. Chandra M, Zhou H, Li Q, Muallem S, Hofmann SL and Soyombo AA. (2011) A role for the Ca2+ channel TRPML1 in gastric acid secretion, based on analysis of knockout mice. Gastroenterology 140: 857-67 [PMID:21111738]

131. Chang Q, Hoefs S, van der Kemp AW, Topala CN, Bindels RJ and Hoenderop JG. (2005) The beta-glucuronidase klotho hydrolyzes and activates the TRPV5 channel. Science 310: 490-3 [PMID:16239475]

132. Chaudhari SS, Kadam AB, Khairatkar-Joshi N, Mukhopadhyay I, Karnik PV, Raghuram A, Rao SS, Vaiyapuri TS, Wale DP and Bhosale VM et al.. (2013) Synthesis and pharmacological evaluation of novel N-aryl-3,4-dihydro-1'H-spiro[chromene-2,4'-piperidine]-1'-carboxamides as TRPM8 antagonists. Bioorg Med Chem 21: 6542-53 [PMID:24055075]

133. Chen CC, Keller M, Hess M, Schiffmann R, Urban N, Wolfgardt A, Schaefer M, Bracher F, Biel $\mathrm{M}$ and Wahl-Schott C et al.. (2014) A small molecule restores function to TRPML1 mutant isoforms responsible for mucolipidosis type IV. Nat Commun 5: 4681 [PMID:25119295]

134. Chen CS, Bach G and Pagano RE. (1998) Abnormal transport along the lysosomal pathway in mucolipidosis, type IV disease. Proc Natl Acad Sci USA 95: 6373-8 [PMID:9600972]

135. Chen J, Joshi SK, DiDomenico S, Perner RJ, Mikusa JP, Gauvin DM, Segreti JA, Han P, Zhang XF and Niforatos W et al.. (2011) Selective blockade of TRPA1 channel attenuates pathological pain without altering noxious cold sensation or body temperature regulation. Pain 152: 1165-72 [PMID:21402443]

136. Chen M, Dong Y and Simard JM. (2003) Functional coupling between sulfonylurea receptor type 1 and a nonselective cation channel in reactive astrocytes from adult rat brain. J Neurosci 23: 8568-77 [PMID:13679426]

137. Chen Q, She J, Zeng W, Guo J, Xu H, Bai XC and Jiang Y. (2017) Structure of mammalian endolysosomal TRPML1 channel in nanodiscs. Nature 550: 415-418 [PMID:29019981]

138. Chen X, Numata T, Li M, Mori Y, Orser BA, Jackson MF, Xiong ZG and MacDonald JF. (2010) The modulation of TRPM7 currents by nafamostat mesilate depends directly upon extracellular concentrations of divalent cations. Mol Brain 3: 38 [PMID:21122141]

139. Chen XZ, Vassilev PM, Basora N, Peng JB, Nomura H, Segal Y, Brown EM, Reeders ST, Hediger MA and Zhou J. (1999) Polycystin-L is a calcium-regulated cation channel permeable to calcium ions. Nature 401: 383-6 [PMID:10517637]

140. Cheng H, Beck A, Launay P, Gross SA, Stokes AJ, Kinet JP, Fleig A and Penner R. (2007) TRPM4 controls insulin secretion in pancreatic beta-cells. Cell Calcium 41: 51-61 [PMID:16806463]

141. Cheng KT, Ong HL, Liu X and Ambudkar IS. (2011) Contribution of TRPC1 and Orai1 to $\mathrm{Ca}(2+)$ entry activated by store depletion. Adv Exp Med Biol 704: 435-49 [PMID:21290310]

142. Cheng KT, Ong HL, Liu X and Ambudkar IS. (2013) Contribution and regulation of TRPC channels in store-operated Ca2+ entry. Curr Top Membr 71: 149-79 [PMID:23890115]

143. Cheng X, Jin J, Hu L, Shen D, Dong XP, Samie MA, Knoff J, Eisinger B, Liu ML and Huang SM et al.. (2010) TRP channel regulates EGFR signaling in hair morphogenesis and skin barrier formation. Cell 141: 331-43 [PMID:20403327]

144. Cheng X, Shen D, Samie M and Xu H. (2010) Mucolipins: Intracellular TRPML1-3 channels. FEBS Lett 584: 2013-21 [PMID:20074572]

145. Chu X, Tong Q, Cheung JY, Wozney J, Conrad K, Mazack V, Zhang W, Stahl R, Barber DL and Miller BA. (2004) Interaction of TRPC2 and TRPC6 in erythropoietin modulation of calcium influx. J Biol Chem 279: 10514-22 [PMID:14699131]

146. Chuang HH, Neuhausser WM and Julius D. (2004) The super-cooling agent icilin reveals a mechanism of coincidence detection by a temperature-sensitive TRP channel. Neuron 43: 85969 [PMID:15363396] 
147. Chubanov V, Gudermann T and Schlingmann KP. (2005) Essential role for TRPM6 in epithelial magnesium transport and body magnesium homeostasis. Pflugers Arch 451: 228-34 [PMID:16075242]

148. Chubanov V, Mederos y Schnitzler M, Meißner M, Schäfer S, Abstiens K, Hofmann T and Gudermann T. (2012) Natural and synthetic modulators of SK (K(ca)2) potassium channels inhibit magnesium-dependent activity of the kinase-coupled cation channel TRPM7. Br J Pharmacol 166: 1357-76 [PMID:22242975]

149. Chubanov V, Waldegger S, Mederos y Schnitzler M, Vitzthum H, Sassen MC, Seyberth HW, Konrad M and Gudermann T. (2004) Disruption of TRPM6/TRPM7 complex formation by a mutation in the TRPM6 gene causes hypomagnesemia with secondary hypocalcemia. Proc Natl Acad Sci USA 101: 2894-9 [PMID:14976260]

150. Chung KK, Freestone PS and Lipski J. (2011) Expression and functional properties of TRPM2 channels in dopaminergic neurons of the substantia nigra of the rat. J Neurophysiol 106: 286575 [PMID:21900507]

151. Chung MK, Güler AD and Caterina MJ. (2005) Biphasic currents evoked by chemical or thermal activation of the heat-gated ion channel, TRPV3. J Biol Chem 280: 15928-41 [PMID:15722340]

152. Chung MK, Lee H and Caterina MJ. (2003) Warm temperatures activate TRPV4 in mouse 308 keratinocytes. J Biol Chem 278: 32037-46 [PMID:12783886]

153. Chung MK, Lee H, Mizuno A, Suzuki M and Caterina MJ. (2004) 2-aminoethoxydiphenyl borate activates and sensitizes the heat-gated ion channel TRPV3. J Neurosci 24: 5177-82 [PMID:15175387]

154. Chung YH, Sun Ahn H, Kim D, Hoon Shin D, Su Kim S, Yong Kim K, Bok Lee W and Ik Cha C. (2006) Immunohistochemical study on the distribution of TRPC channels in the rat hippocampus. Brain Res 1085: 132-7 [PMID:16580647]

155. Clapham DE. (2015) Structural biology: Pain-sensing TRPA1 channel resolved. Nature 520: 43941 [PMID:25855290]

156. Clapham DE. (2003) TRP channels as cellular sensors. Nature 426: 517-24 [PMID:14654832]

157. Clapham DE and Garbers DL. (2005) International Union of Pharmacology. L. Nomenclature and structure-function relationships of CatSper and two-pore channels. Pharmacol Rev 57: 451-4 [PMID:16382101]

158. Clapham DE and Miller C. (2011) A thermodynamic framework for understanding temperature sensing by transient receptor potential (TRP) channels. Proc Natl Acad Sci U S A 108: 19492-7 [PMID:22109551]

159. Clapham DE, Montell C, Schultz G, Julius D and International Union of Pharmacology. (2003) International Union of Pharmacology. XLIII. Compendium of voltage-gated ion channels: transient receptor potential channels. Pharmacol Rev 55: 591-6 [PMID:14657417]

160. Clark K, Langeslag M, van Leeuwen B, Ran L, Ryazanov AG, Figdor CG, Moolenaar WH, Jalink K and van Leeuwen FN. (2006) TRPM7, a novel regulator of actomyosin contractility and cell adhesion. EMBO J 25: 290-301 [PMID:16407977]

161. Colburn RW, Lubin ML, Stone DJ, Wang Y, Lawrence D, D'Andrea MR, Brandt MR, Liu Y, Flores CM and Qin N. (2007) Attenuated cold sensitivity in TRPM8 null mice. Neuron 54: 379-86 [PMID:17481392]

162. Colletti GA, Miedel MT, Quinn J, Andharia N, Weisz OA and Kiselyov K. (2012) Loss of lysosomal ion channel transient receptor potential channel mucolipin-1 (TRPML1) leads to cathepsin Bdependent apoptosis. J Biol Chem 287: 8082-91 [PMID:22262857]

163. Colsoul B, Schraenen A, Lemaire K, Quintens R, Van Lommel L, Segal A, Owsianik G, Talavera $\mathrm{K}$, Voets T and Margolskee RF et al.. (2010) Loss of high-frequency glucose-induced Ca2+ oscillations in pancreatic islets correlates with impaired glucose tolerance in Trpm5-/- mice. Proc Natl Acad Sci USA 107: 5208-13 [PMID:20194741]

164. Compan V, Baroja-Mazo A, López-Castejón G, Gomez AI, Martínez CM, Angosto D, Montero MT, Herranz AS, Bazán E and Reimers D et al.. (2012) Cell volume regulation modulates NLRP3 inflammasome activation. Immunity 37: 487-500 [PMID:22981536]

165. Cordeiro S, Seyler S, Stindl J, Milenkovic VM and Strauss O. (2010) Heat-sensitive TRPV channels in retinal pigment epithelial cells: regulation of VEGF-A secretion. Invest Ophthalmol Vis Sci 51: 6001-8 [PMID:20539001]

166. Corey DP, García-Añoveros J, Holt JR, Kwan KY, Lin SY, Vollrath MA, Amalfitano A, Cheung EL, Derfler BH and Duggan A et al.. (2004) TRPA1 is a candidate for the mechanosensitive transduction channel of vertebrate hair cells. Nature 432: 723-30 [PMID:15483558]

167. Correll CC, Phelps PT, Anthes JC, Umland S and Greenfeder S. (2004) Cloning and pharmacological characterization of mouse TRPV1. Neurosci Lett 370: 55-60 [PMID:15489017]

168. Coste B, Mathur J, Schmidt M, Earley TJ, Ranade S, Petrus MJ, Dubin AE and Patapoutian A. (2010) Piezo1 and Piezo2 are essential components of distinct mechanically activated cation channels. Science 330: 55-60 [PMID:20813920]

169. Coste B, Xiao B, Santos JS, Syeda R, Grandl J, Spencer KS, Kim SE, Schmidt M, Mathur J and Dubin AE et al.. (2012) Piezo proteins are pore-forming subunits of mechanically activated 
channels. Nature 483: 176-81 [PMID:22343900]

170. Cruz-Torres I, Backos DS and Herson PS. (2020) Characterization and Optimization of the Novel Transient Receptor Potential Melastatin 2 Antagonist tatM2NX. Mol Pharmacol 97: 102-111 [PMID:31772034]

171. Cuajungco MP, Grimm C, Oshima K, D'hoedt D, Nilius B, Mensenkamp AR, Bindels RJ, Plomann $\mathrm{M}$ and Heller S. (2006) PACSINs bind to the TRPV4 cation channel. PACSIN 3 modulates the subcellular localization of TRPV4. J Biol Chem 281: 18753-62 [PMID:16627472]

172. Cuajungco MP and Samie MA. (2008) The varitint-waddler mouse phenotypes and the TRPML3 ion channel mutation: cause and consequence. Pflugers Arch 457: 463-73 [PMID:18504603]

173. Cuajungco MP, Silva J, Habibi A and Valadez JA. (2016) The mucolipin-2 (TRPML2) ion channel: a tissue-specific protein crucial to normal cell function. Pflugers Arch 468: 177-92 [PMID:26336837]

174. Curcio-Morelli C, Charles FA, Micsenyi MC, Cao Y, Venugopal B, Browning MF, Dobrenis K, Cotman SL, Walkley SU and Slaugenhaupt SA. (2010) Macroautophagy is defective in mucolipin1-deficient mouse neurons. Neurobiol Dis 40: 370-7 [PMID:20600908]

175. Curcio-Morelli C, Zhang P, Venugopal B, Charles FA, Browning MF, Cantiello HF and Slaugenhaupt SA. (2010) Functional multimerization of mucolipin channel proteins. J Cell Physiol 222: 328-35 [PMID:19885840]

176. da Costa DS, Meotti FC, Andrade EL, Leal PC, Motta EM and Calixto JB. (2010) The involvement of the transient receptor potential A1 (TRPA1) in the maintenance of mechanical and cold hyperalgesia in persistent inflammation. Pain 148: 431-7 [PMID:20056530]

177. Dai XQ, Ramji A, Liu Y, Li Q, Karpinski E and Chen XZ. (2007) Inhibition of TRPP3 channel by amiloride and analogs. Mol Pharmacol 72: 1576-85 [PMID:17804601]

178. Damak S, Rong M, Yasumatsu K, Kokrashvili Z, Pérez CA, Shigemura N, Yoshida R, Mosinger Jr B, Glendinning JI and Ninomiya Y et al.. (2006) Trpm5 null mice respond to bitter, sweet, and umami compounds. Chem Senses 31: 253-64 [PMID:16436689]

179. Danso-Abeam D, Zhang J, Dooley J, Staats KA, Van Eyck L, Van Brussel T, Zaman S, Hauben E, Van de Velde $M$ and Morren MA et al.. (2013) Olmsted syndrome: exploration of the immunological phenotype. Orphanet J Rare Dis 8: 79 [PMID:23692804]

180. Dattilo M, Penington NJ and Williams K. (2008) Inhibition of TRPC5 channels by intracellular ATP. Mol Pharmacol 73: 42-9 [PMID:17925457]

181. Davare MA, Fortin DA, Saneyoshi T, Nygaard S, Kaech S, Banker G, Soderling TR and Wayman GA. (2009) Transient receptor potential canonical 5 channels activate Ca2+/calmodulin kinase Igamma to promote axon formation in hippocampal neurons. J Neurosci 29: 9794-808 [PMID:19657032]

182. Davis J, Burr AR, Davis GF, Birnbaumer L and Molkentin JD. (2012) A TRPC6-dependent pathway for myofibroblast transdifferentiation and wound healing in vivo. Dev Cell 23: 705-15 [PMID:23022034]

183. Davis JB, Gray J, Gunthorpe MJ, Hatcher JP, Davey PT, Overend P, Harries MH, Latcham J, Clapham C and Atkinson K et al.. (2000) Vanilloid receptor-1 is essential for inflammatory thermal hyperalgesia. Nature 405: 183-7 [PMID:10821274]

184. Davis MI, Hunt JP, Herrgard S, Ciceri P, Wodicka LM, Pallares G, Hocker M, Treiber DK and Zarrinkar PP. (2011) Comprehensive analysis of kinase inhibitor selectivity. Nat Biotechnol 29: 1046-51 [PMID:22037378]

185. de Groot T, Bindels RJ and Hoenderop JG. (2008) TRPV5: an ingeniously controlled calcium channel. Kidney Int 74: 1241-6 [PMID:18596722]

186. de Groot T, Lee K, Langeslag M, Xi Q, Jalink K, Bindels RJ and Hoenderop JG. (2009) Parathyroid hormone activates TRPV5 via PKA-dependent phosphorylation. J Am Soc Nephrol 20: 1693-704 [PMID:19423690]

187. De March Z, Giampà C, Patassini S, Bernardi G and Fusco FR. (2006) Cellular localization of TRPC5 in the substantia nigra of rat. Neurosci Lett 402: 35-9 [PMID:16635549]

188. De Petrocellis L, Orlando P, Moriello AS, Aviello G, Stott C, Izzo AA and Di Marzo V. (2012) Cannabinoid actions at TRPV channels: effects on TRPV3 and TRPV4 and their potential relevance to gastrointestinal inflammation. Acta Physiol (Oxf) 204: 255-66 [PMID:21726418]

189. DeCaen PG, Delling M, Vien TN and Clapham DE. (2013) Direct recording and molecular identification of the calcium channel of primary cilia. Nature 504: 315-8 [PMID:24336289]

190. DeCaen PG, Liu X, Abiria S and Clapham DE. (2016) Atypical calcium regulation of the PKD2-L1 polycystin ion channel. Elife 5 [PMID:27348301]

191. Deeds J, Cronin F and Duncan LM. (2000) Patterns of melastatin mRNA expression in melanocytic tumors. Hum Pathol 31: 1346-56 [PMID:11112208]

192. DeHaven WI, Jones BF, Petranka JG, Smyth JT, Tomita T, Bird GS and Putney Jr JW. (2009) TRPC channels function independently of STIM1 and Orai1.J Physiol (Lond.) 587: 2275-98 [PMID:19332491]

193. del Camino D, Murphy S, Heiry M, Barrett LB, Earley TJ, Cook CA, Petrus MJ, Zhao M, D'Amours M and Deering N et al.. (2010) TRPA1 contributes to cold hypersensitivity. J Neurosci 
30: 15165-74 [PMID:21068322]

194. Delany NS, Hurle M, Facer P, Alnadaf T, Plumpton C, Kinghorn I, See CG, Costigan M, Anand P and Woolf CJ et al.. (2001) Identification and characterization of a novel human vanilloid receptor-like protein, VRL-2. Physiol Genomics 4: 165-74 [PMID:11160995]

195. Delmas P. (2005) Polycystins: polymodal receptor/ion-channel cellular sensors. Pflugers Arch 451: 264-76 [PMID:15889307]

196. Delmas P, Nauli SM, Li X, Coste B, Osorio N, Crest M, Brown DA and Zhou J. (2004) Gating of the polycystin ion channel signaling complex in neurons and kidney cells. FASEB J 18: 740-2 [PMID:14766803]

197. Delmas P, Padilla F, Osorio N, Coste B, Raoux M and Crest M. (2004) Polycystins, calcium signaling, and human diseases. Biochem Biophys Res Commun 322: 1374-83 [PMID:15336986]

198. Dembla S, Behrendt M, Mohr F, Goecke C, Sondermann J, Schneider FM, Schmidt M, Stab J, Enzeroth R and Leitner MG et al.. (2017) Anti-nociceptive action of peripheral mu-opioid receptors by G-beta-gamma protein-mediated inhibition of TRPM3 channels. Elife 6 [PMID:28826482]

199. Deng HX, Klein CJ, Yan J, Shi Y, Wu Y, Fecto F, Yau HJ, Yang Y, Zhai H and Siddique N et al.. (2010) Scapuloperoneal spinal muscular atrophy and CMT2C are allelic disorders caused by alterations in TRPV4. Nat Genet 42: 165-9 [PMID:20037587]

200. Deng Z, Paknejad N, Maksaev G, Sala-Rabanal M, Nichols CG, Hite RK and Yuan P. (2018) CryoEM and X-ray structures of TRPV4 reveal insight into ion permeation and gating mechanisms. Nat Struct Mol Biol 25: 252-260 [PMID:29483651]

201. Deol MS. (1954) The anomalies of the labyrinth of the mutants varitint-waddler, shaker-2 and jerker in the mouse. Journal of Genetics 52: 558

202. Desai BN, Krapivinsky G, Navarro B, Krapivinsky L, Carter BC, Febvay S, Delling M, Penumaka A, Ramsey IS and Manasian Y et al.. (2012) Cleavage of TRPM7 releases the kinase domain from the ion channel and regulates its participation in Fas-induced apoptosis. Dev Cell 22: 1149-62 [PMID:22698280]

203. Devi S, Markandeya Y, Maddodi N, Dhingra A, Vardi N, Balijepalli RC and Setaluri V. (2013) Metabotropic glutamate receptor 6 signaling enhances TRPM1 calcium channel function and increases melanin content in human melanocytes. Pigment Cell Melanoma Res 26: 348-56 [PMID:23452348]

204. Dhaka A, Earley TJ, Watson J and Patapoutian A. (2008) Visualizing cold spots: TRPM8expressing sensory neurons and their projections. J Neurosci 28: 566-75 [PMID:18199758]

205. Dhaka A, Murray AN, Mathur J, Earley TJ, Petrus MJ and Patapoutian A. (2007) TRPM8 is required for cold sensation in mice. Neuron 54: 371-8 [PMID:17481391]

206. Dhaka A, Viswanath V and Patapoutian A. (2006) Trp ion channels and temperature sensation. Annu Rev Neurosci 29: 135-61 [PMID:16776582]

207. Dhingra A, Fina ME, Neinstein A, Ramsey DJ, Xu Y, Fishman GA, Alexander KR, Qian H, Peachey NS and Gregg RG et al.. (2011) Autoantibodies in melanoma-associated retinopathy target TRPM1 cation channels of retinal ON bipolar cells. J Neurosci 31: 3962-7 [PMID:21411639]

208. Di A, Gao XP, Qian F, Kawamura T, Han J, Hecquet C, Ye RD, Vogel SM and Malik AB. (2012) The redox-sensitive cation channel TRPM2 modulates phagocyte ROS production and inflammation. Nat Immunol 13: 29-34 [PMID:22101731]

209. Di Palma F, Belyantseva IA, Kim HJ, Vogt TF, Kachar B and Noben-Trauth K. (2002) Mutations in Mcoln3 associated with deafness and pigmentation defects in varitint-waddler (Va) mice. Proc Natl Acad Sci USA 99: 14994-9 [PMID:12403827]

210. Dietrich A, Fahlbusch M and Gudermann T. (2014) Classical Transient Receptor Potential 1 (TRPC1): Channel or Channel Regulator? Cells 3: 939-62 [PMID:25268281]

211. Dietrich A, Kalwa H, Rost BR and Gudermann T. (2005) The diacylgylcerol-sensitive TRPC3/6/7 subfamily of cation channels: functional characterization and physiological relevance. Pflugers Arch 451: 72-80 [PMID:15971081]

212. Dietrich A, Mederos Y Schnitzler M, Gollasch M, Gross V, Storch U, Dubrovska G, Obst M, Yildirim E, Salanova B and Kalwa $\mathrm{H}$ et al.. (2005) Increased vascular smooth muscle contractility in TRPC6-/- mice. Mol Cell Biol 25: 6980-9 [PMID:16055711]

213. Doerner JF, Hatt $H$ and Ramsey IS. (2011) Voltage- and temperature-dependent activation of TRPV3 channels is potentiated by receptor-mediated PI(4,5)P2 hydrolysis. J Gen Physiol 137: 271-88 [PMID:21321070]

214. Dong XP, Cheng X, Mills E, Delling M, Wang F, Kurz T and Xu H. (2008) The type IV mucolipidosis-associated protein TRPML1 is an endolysosomal iron release channel. Nature 455: 992-6 [PMID:18794901]

215. Dong XP, Shen D, Wang X, Dawson T, Li X, Zhang Q, Cheng X, Zhang Y, Weisman LS and Delling $\mathrm{M}$ et al.. (2010) $\mathrm{PI}(3,5) \mathrm{P}(2)$ controls membrane trafficking by direct activation of mucolipin $\mathrm{Ca}(2+)$ release channels in the endolysosome. Nat Commun 1: 38 [PMID:20802798]

216. Dong XP, Wang X, Shen D, Chen S, Liu M, Wang Y, Mills E, Cheng X, Delling M and Xu H. (2009) Activating mutations of the TRPML1 channel revealed by proline-scanning mutagenesis. $J$ 
Biol Chem 284: 32040-52 [PMID:19638346]

217. Dorovkov MV and Ryazanov AG. (2004) Phosphorylation of annexin I by TRPM7 channel-kinase. J Biol Chem 279: 50643-6 [PMID:15485879]

218. Doñate-Macian P, Duarte Y, Rubio-Moscardo F, Pérez-Vilaró G, Canan J, Díez J, González-Nilo F and Valverde MA. (2020) Structural determinants of TRPV4 inhibition and identification of new antagonists with antiviral activity. Br J Pharmacol [PMID:32959389]

219. Du J, Xie J and Yue L. (2009) Intracellular calcium activates TRPM2 and its alternative spliced isoforms. Proc Natl Acad Sci USA 106: 7239-44 [PMID:19372375]

220. Du J, Xie J and Yue L. (2009) Modulation of TRPM2 by acidic $\mathrm{pH}$ and the underlying mechanisms for pH sensitivity. J Gen Physiol 134: 471-88 [PMID:19917732]

221. Du J, Xie J, Zhang Z, Tsujikawa H, Fusco D, Silverman D, Liang B and Yue L. (2010) TRPM7mediated $\mathrm{Ca} 2+$ signals confer fibrogenesis in human atrial fibrillation. Circ Res 106: 992-1003 [PMID:20075334]

222. Du S, Araki I, Yoshiyama M, Nomura T and Takeda M. (2007) Transient receptor potential channel A1 involved in sensory transduction of rat urinary bladder through C-fiber pathway. Urology 70: 826-31 [PMID:17991581]

223. Duncan LM, Deeds J, Cronin FE, Donovan M, Sober AJ, Kauffman M and McCarthy JJ. (2001) Melastatin expression and prognosis in cutaneous malignant melanoma. J Clin Oncol 19: 568-76 [PMID:11208852]

224. Duncan LM, Deeds J, Hunter J, Shao J, Holmgren LM, Woolf EA, Tepper RI and Shyjan AW. (1998) Down-regulation of the novel gene melastatin correlates with potential for melanoma metastasis. Cancer Res 58: 1515-20 [PMID:9537257]

225. Dunn KM, Hill-Eubanks DC, Liedtke WB and Nelson MT. (2013) TRPV4 channels stimulate $\mathrm{Ca} 2+$-induced $\mathrm{Ca} 2+$ release in astrocytic endfeet and amplify neurovascular coupling responses. Proc Natl Acad Sci USA 110: 6157-62 [PMID:23530219]

226. Dutta Banik D, Martin LE, Freichel M, Torregrossa AM and Medler KF. (2018) TRPM4 and TRPM5 are both required for normal signaling in taste receptor cells. Proc Natl Acad Sci USA 115: E772-E781 [PMID:29311301]

227. Earley S, Gonzales AL and Crnich R. (2009) Endothelium-dependent cerebral artery dilation mediated by TRPA1 and Ca2+-Activated K+ channels. Circ Res 104: 987-94 [PMID:19299646]

228. Earley S, Pauyo T, Drapp R, Tavares MJ, Liedtke W and Brayden JE. (2009) TRPV4-dependent dilation of peripheral resistance arteries influences arterial pressure. Am J Physiol Heart Circ Physiol 297: H1096-102 [PMID:19617407]

229. Earley S, Waldron BJ and Brayden JE. (2004) Critical role for transient receptor potential channel TRPM4 in myogenic constriction of cerebral arteries. Circ Res 95: 922-9 [PMID:15472118]

230. Eberhardt MJ, Filipovic MR, Leffler A, de la Roche J, Kistner K, Fischer MJ, Fleming T, Zimmermann K, Ivanovic-Burmazovic I and Nawroth PP et al.. (2012) Methylglyoxal activates nociceptors through transient receptor potential channel A1 (TRPA1): a possible mechanism of metabolic neuropathies. J Biol Chem 287: 28291-306 [PMID:22740698]

231. Eichelsdoerfer JL, Evans JA, Slaugenhaupt SA and Cuajungco MP. (2010) Zinc dyshomeostasis is linked with the loss of mucolipidosis IV-associated TRPML1 ion channel. J Biol Chem 285: 34304-8 [PMID:20864526]

232. Eid SR, Crown ED, Moore EL, Liang HA, Choong KC, Dima S, Henze DA, Kane SA and Urban MO. (2008) HC-030031, a TRPA1 selective antagonist, attenuates inflammatory- and neuropathy-induced mechanical hypersensitivity. Mol Pain 4: 48 [PMID:18954467]

233. El Karim IA, Linden GJ, Curtis TM, About I, McGahon MK, Irwin CR, Killough SA and Lundy FT. (2011) Human dental pulp fibroblasts express the "cold-sensing" transient receptor potential channels TRPA1 and TRPM8. J Endod 37: 473-8 [PMID:21419293]

234. El Karim IA, Linden GJ, Curtis TM, About I, McGahon MK, Irwin CR and Lundy FT. (2011) Human odontoblasts express functional thermo-sensitive TRP channels: implications for dentin sensitivity. Pain 152: 2211-23 [PMID:21168271]

235. El Kouhen R, Surowy CS, Bianchi BR, Neelands TR, McDonald HA, Niforatos W, Gomtsyan A, Lee CH, Honore P and Sullivan JP et al.. (2005) A-425619 [1-isoquinolin-5-yl-3-(4trifluoromethyl-benzyl)-urea], a novel and selective transient receptor potential type V1 receptor antagonist, blocks channel activation by vanilloids, heat, and acid. J Pharmacol Exp Ther 314: 400-9 [PMID:15837819]

236. Emir TLR. (2017) various In Neurobiology of TRP Channels (2nd Ed.) Edited by Emir TLR: CRC Press/Taylor \& Francis: [PMID:29356469]

237. Engel MA, Leffler A, Niedermirtl F, Babes A, Zimmermann K, Filipović MR, Izydorczyk I, Eberhardt M, Kichko TI and Mueller-Tribbensee SM et al.. (2011) TRPA1 and substance P mediate colitis in mice. Gastroenterology 141: 1346-58 [PMID:21763243]

238. Enklaar T, Esswein M, Oswald M, Hilbert K, Winterpacht A, Higgins M, Zabel B and Prawitt D. (2000) Mtr1, a novel biallelically expressed gene in the center of the mouse distal chromosome 7 imprinting cluster, is a member of the Trp gene family. Genomics 67: 179-87 [PMID:10903843] 
239. Erickson LA, Letts GA, Shah SM, Shackelton JB and Duncan LM. (2009) TRPM1 (Melastatin1/MLSN1) mRNA expression in Spitz nevi and nodular melanomas. Mod Pathol 22: 969-76 [PMID:19396153]

240. Erler I, Hirnet D, Wissenbach U, Flockerzi V and Niemeyer BA. (2004) Ca2+-selective transient receptor potential $\mathrm{V}$ channel architecture and function require a specific ankyrin repeat. J Biol Chem 279: 34456-63 [PMID:15192090]

241. Escalera J, von Hehn CA, Bessac BF, Sivula M and Jordt SE. (2008) TRPA1 mediates the noxious effects of natural sesquiterpene deterrents. J Biol Chem 283: 24136-44 [PMID:18550530]

242. Everaerts W, Vriens J, Owsianik G, Appendino G, Voets T, De Ridder D and Nilius B. (2010) Functional characterization of transient receptor potential channels in mouse urothelial cells. Am J Physiol Renal Physiol 298: F692-701 [PMID:20015940]

243. Everaerts W, Zhen X, Ghosh D, Vriens J, Gevaert T, Gilbert JP, Hayward NJ, McNamara CR, Xue F and Moran MM et al.. (2010) Inhibition of the cation channel TRPV4 improves bladder function in mice and rats with cyclophosphamide-induced cystitis. Proc Natl Acad Sci USA 107: 19084-9 [PMID:20956320]

244. Facemire CS, Mohler PJ and Arendshorst WJ. (2004) Expression and relative abundance of short transient receptor potential channels in the rat renal microcirculation. Am J Physiol Renal Physiol 286: F546-51 [PMID:14678949]

245. Fajardo O, Meseguer V, Belmonte C and Viana F. (2008) TRPA1 channels mediate cold temperature sensing in mammalian vagal sensory neurons: pharmacological and genetic evidence. J Neurosci 28: 7863-75 [PMID:18667618]

246. Falardeau JL, Kennedy JC, Acierno Jr JS, Sun M, Stahl S, Goldin E and Slaugenhaupt SA. (2002) Cloning and characterization of the mouse Mcoln1 gene reveals an alternatively spliced transcript not seen in humans. BMC Genomics 3: 3 [PMID:11897010]

247. Fantozzi I, Zhang S, Platoshyn O, Remillard CV, Cowling RT and Yuan JX. (2003) Hypoxia increases AP-1 binding activity by enhancing capacitative Ca2+ entry in human pulmonary artery endothelial cells. Am J Physiol Lung Cell Mol Physiol 285: L1233-45 [PMID:12909593]

248. Fecher-Trost C, Weissgerber P and Wissenbach U. (2014) TRPV6 channels. Handb Exp Pharmacol 222: 359-84 [PMID:24756713]

249. Feng Q. (2014) Temperature sensing by thermal TRP channels: thermodynamic basis and molecular insights. Curr Top Membr 74: 19-50 [PMID:25366232]

250. Fernandes ES, Vong CT, Quek S, Cheong J, Awal S, Gentry C, Aubdool AA, Liang L, Bodkin JV and Bevan S et al.. (2013) Superoxide generation and leukocyte accumulation: key elements in the mediation of leukotriene $\mathrm{B}_{4}$-induced itch by transient receptor potential ankyrin 1 and transient receptor potential vanilloid 1. FASEB J 27: 1664-73 [PMID:23271050]

251. Fernihough J, Gentry C, Bevan S and Winter J. (2005) Regulation of calcitonin gene-related peptide and TRPV1 in a rat model of osteoarthritis. Neurosci Lett 388: 75-80 [PMID:16039054]

252. Fleig A and Penner R. (2004) The TRPM ion channel subfamily: molecular, biophysical and functional features. Trends Pharmacol Sci 25: 633-9 [PMID:15530641]

253. Fliegert R, Bauche A, Wolf Pérez AM, Watt JM, Rozewitz MD, Winzer R, Janus M, Gu F, Rosche A and Harneit A et al.. (2017) 2'-Deoxyadenosine 5'-diphosphoribose is an endogenous TRPM2 superagonist. Nat Chem Biol 13: 1036-1044 [PMID:28671679]

254. Fois G, Wittekindt O, Zheng X, Felder ET, Miklavc P, Frick M, Dietl P and Felder E. (2012) An ultra fast detection method reveals strain-induced $\mathrm{Ca}(2+)$ entry via TRPV2 in alveolar type II cells. Biomech Model Mechanobiol 11: 959-71 [PMID:22190268]

255. Fonfria E, Marshall IC, Benham CD, Boyfield I, Brown JD, Hill K, Hughes JP, Skaper SD and McNulty S. (2004) TRPM2 channel opening in response to oxidative stress is dependent on activation of poly(ADP-ribose) polymerase. Br J Pharmacol 143: 186-92 [PMID:15302683]

256. Fonfria E, Marshall IC, Boyfield I, Skaper SD, Hughes JP, Owen DE, Zhang W, Miller BA, Benham CD and McNulty S. (2005) Amyloid beta-peptide(1-42) and hydrogen peroxide-induced toxicity are mediated by TRPM2 in rat primary striatal cultures. J Neurochem 95: 715-23 [PMID:16104849]

257. Fonfria E, Mattei C, Hill K, Brown JT, Randall A, Benham CD, Skaper SD, Campbell CA, Crook B and Murdock PR et al.. (2006) TRPM2 is elevated in the tMCAO stroke model, transcriptionally regulated, and functionally expressed in C13 microglia. J Recept Signal Transduct Res 26: 17998 [PMID:16777714]

258. Fonfria E, Murdock PR, Cusdin FS, Benham CD, Kelsell RE and McNulty S. (2006) Tissue distribution profiles of the human TRPM cation channel family. J Recept Signal Transduct Res 26: 159-78 [PMID:16777713]

259. Frederick J, Buck ME, Matson DJ and Cortright DN. (2007) Increased TRPA1, TRPM8, and TRPV2 expression in dorsal root ganglia by nerve injury. Biochem Biophys Res Commun 358: 1058-64 [PMID:17517374]

260. Freichel M, Suh SH, Pfeifer A, Schweig U, Trost C, Weissgerber P, Biel M, Philipp S, Freise D and Droogmans G et al.. (2001) Lack of an endothelial store-operated Ca2+ current impairs agonist-dependent vasorelaxation in TRP4-/- mice. Nat Cell Biol 3: 121-7 [PMID:11175743] 
261. Freichel M, Vennekens R, Olausson J, Stolz S, Philipp SE, Weissgerber P and Flockerzi V. (2005) Functional role of TRPC proteins in native systems: implications from knockout and knock-down studies. J Physiol (Lond.) 567: 59-66 [PMID:15975974]

262. Friedlova E, Grycova L, Holakovska B, Silhan J, Janouskova H, Sulc M, Obsilova V, Obsil T and Teisinger J. (2010) The interactions of the C-terminal region of the TRPC6 channel with calmodulin. Neurochem Int 56: 363-6 [PMID:19932145]

263. Fujita F, Moriyama T, Higashi T, Shima A and Tominaga M. (2007) Methyl p-hydroxybenzoate causes pain sensation through activation of TRPA1 channels. Br J Pharmacol 151: 153-60 [PMID:17351650]

264. Fujita F, Uchida K, Moriyama T, Shima A, Shibasaki K, Inada H, Sokabe T and Tominaga M. (2008) Intracellular alkalization causes pain sensation through activation of TRPA1 in mice. $J$ Clin Invest 118: 4049-57 [PMID:19033673]

265. Galizia L, Pizzoni A, Fernandez J, Rivarola V, Capurro C and Ford P. (2012) Functional interaction between AQP2 and TRPV4 in renal cells. J Cell Biochem 113: 580-9 [PMID:21938744]

266. Gallagher AR, Cedzich A, Gretz N, Somlo S and Witzgall R. (2000) The polycystic kidney disease protein PKD2 interacts with Hax-1, a protein associated with the actin cytoskeleton. Proc Natl Acad Sci USA 97: 4017-22 [PMID:10760273]

267. Garcia ZI, Bruhl A, Gonzales AL and Earley S. (2011) Basal protein kinase C6 activity is required for membrane localization and activity of TRPM4 channels in cerebral artery smooth muscle cells. Channels (Austin) 5: 210-4 [PMID:21406958]

268. García-Añoveros J and Nagata K. (2007) TRPA1. Handb Exp Pharmacol: 347-62 [PMID:17217068]

269. Gasser A, Glassmeier G, Fliegert R, Langhorst MF, Meinke S, Hein D, Krüger S, Weber K, Heiner I and Oppenheimer N et al.. (2006) Activation of T cell calcium influx by the second messenger ADP-ribose. J Biol Chem 281: 2489-96 [PMID:16316998]

270. Gaunt HJ, Vasudev NS and Beech DJ. (2016) Transient receptor potential canonical 4 and 5 proteins as targets in cancer therapeutics. Eur Biophys J 45: 611-620 [PMID:27289383]

271. Gavva NR, Tamir R, Qu Y, Klionsky L, Zhang TJ, Immke D, Wang J, Zhu D, Vanderah TW and Porreca F et al.. (2005) AMG 9810 [(E)-3-(4-t-butylphenyl)-N-(2,3-dihydrobenzo[b][1,4] dioxin-6yl)acrylamide], a novel vanilloid receptor 1 (TRPV1) antagonist with antihyperalgesic properties. J Pharmacol Exp Ther 313: 474-84 [PMID:15615864]

272. Gees M, Owsianik G, Nilius B and Voets T. (2012) TRP channels. Compr Physiol 2: 563-608 [PMID:23728980]

273. Geppetti P and Trevisani M. (2004) Activation and sensitisation of the vanilloid receptor: role in gastrointestinal inflammation and function. Br J Pharmacol 141: 1313-20 [PMID:15051629]

274. Gevaert T, Vriens J, Segal A, Everaerts W, Roskams T, Talavera K, Owsianik G, Liedtke W, Daelemans D and Dewachter I et al.. (2007) Deletion of the transient receptor potential cation channel TRPV4 impairs murine bladder voiding. J Clin Invest 117: 3453-62 [PMID:17948126]

275. Giamarchi A, Padilla F, Coste B, Raoux M, Crest M, Honoré E and Delmas P. (2006) The versatile nature of the calcium-permeable cation channel TRPP2. EMBO Rep 7: 787-93 [PMID:16880824]

276. Gibbs JL, Melnyk JL and Basbaum AI. (2011) Differential TRPV1 and TRPV2 channel expression in dental pulp. J Dent Res 90: 765-70 [PMID:21406609]

277. Gibbs RA, Weinstock GM, Metzker ML, Muzny DM, Sodergren EJ, Scherer S, Scott G, Steffen D, Worley KC and Burch PE et al.. (2004) Genome sequence of the Brown Norway rat yields insights into mammalian evolution. Nature 428: 493-521 [PMID:15057822]

278. Gilliam JC and Wensel TG. (2011) TRP channel gene expression in the mouse retina. Vision Res 51: 2440-52 [PMID:22037305]

279. Gkika D, Hsu YJ, van der Kemp AW, Christakos S, Bindels RJ and Hoenderop JG. (2006) Critical role of the epithelial Ca2+ channel TRPV5 in active Ca2+ reabsorption as revealed by TRPV5/calbindin-D28K knockout mice. J Am Soc Nephrol 17: 3020-7 [PMID:17005931]

280. Gkika D, Mahieu F, Nilius B, Hoenderop JG and Bindels RJ. (2004) 80K-H as a new Ca2+ sensor regulating the activity of the epithelial $\mathrm{Ca} 2+$ channel transient receptor potential cation channel V5 (TRPV5). J Biol Chem 279: 26351-7 [PMID:15100231]

281. Gomtsyan A, Schmidt RG, Bayburt EK, Gfesser GA, Voight EA, Daanen JF, Schmidt DL, Cowart MD, Liu H and Altenbach RJ et al.. (2016) Synthesis and Pharmacology of (Pyridin-2-yl)methanol Derivatives as Novel and Selective Transient Receptor Potential Vanilloid 3 Antagonists. J Med Chem 59: 4926-47 [PMID:27077528]

282. Gonzalez-Perrett S, Batelli M, Kim K, Essafi M, Timpanaro G, Moltabetti N, Reisin IL, Arnaout MA and Cantiello HF. (2002) Voltage dependence and pH regulation of human polycystin-2mediated cation channel activity. J Biol Chem 277: 24959-66 [PMID:11991947]

283. Gottlieb P, Folgering J, Maroto R, Raso A, Wood TG, Kurosky A, Bowman C, Bichet D, Patel A and Sachs F et al.. (2008) Revisiting TRPC1 and TRPC6 mechanosensitivity. Pflugers Arch 455: 1097-103 [PMID:17957383] 
284. Grace MS, Baxter M, Dubuis E, Birrell MA and Belvisi MG. (2014) Transient receptor potential (TRP) channels in the airway: role in airway disease. Br J Pharmacol 171: 2593-607 [PMID:24286227]

285. Gracheva EO, Ingolia NT, Kelly YM, Cordero-Morales JF, Hollopeter G, Chesler AT, Sánchez EE, Perez JC, Weissman JS and Julius D. (2010) Molecular basis of infrared detection by snakes. Nature 464: 1006-11 [PMID:20228791]

286. Gradilone SA, Masyuk AI, Splinter PL, Banales JM, Huang BQ, Tietz PS, Masyuk TV and Larusso NF. (2007) Cholangiocyte cilia express TRPV4 and detect changes in luminal tonicity inducing bicarbonate secretion. Proc Natl Acad Sci USA 104: 19138-43 [PMID:18024594]

287. Grand T, Demion M, Norez C, Mettey Y, Launay P, Becq F, Bois P and Guinamard R. (2008) 9phenanthrol inhibits human TRPM4 but not TRPM5 cationic channels. Br J Pharmacol 153: 1697-705 [PMID:18297105]

288. Gratzke C, Streng T, Waldkirch E, Sigl K, Stief C, Andersson KE and Hedlund P. (2009) Transient receptor potential A1 (TRPA1) activity in the human urethra--evidence for a functional role for TRPA1 in the outflow region. Eur Urol 55: 696-704 [PMID:18468780]

289. Gregus AM, Doolen S, Dumlao DS, Buczynski MW, Takasusuki T, Fitzsimmons BL, Hua XY, Taylor BK, Dennis EA and Yaksh TL. (2012) Spinal 12-lipoxygenase-derived hepoxilin A3 contributes to inflammatory hyperalgesia via activation of TRPV1 and TRPA1 receptors. Proc Natl Acad Sci USA 109: 6721-6 [PMID:22493235]

290. Greka A, Navarro B, Oancea E, Duggan A and Clapham DE. (2003) TRPC5 is a regulator of hippocampal neurite length and growth cone morphology. Nat Neurosci 6: 837-45 [PMID:12858178]

291. Grimm C. (2016) Endolysosomal Cation Channels as Therapeutic Targets-Pharmacology of TRPML Channels Messenger 5: 30-36

292. Grimm C, Cuajungco MP, van Aken AF, Schnee M, Jörs S, Kros CJ, Ricci AJ and Heller S. (2007) A helix-breaking mutation in TRPML3 leads to constitutive activity underlying deafness in the varitint-waddler mouse. Proc Natl Acad Sci USA 104: 19583-8 [PMID:18048323]

293. Grimm C, Jörs S, Guo Z, Obukhov AG and Heller S. (2012) Constitutive activity of TRPML2 and TRPML3 channels versus activation by low extracellular sodium and small molecules. J Biol Chem 287: 22701-8 [PMID:22753890]

294. Grimm C, Jörs S, Saldanha SA, Obukhov AG, Pan B, Oshima K, Cuajungco MP, Chase P, Hodder $\mathrm{P}$ and Heller S. (2010) Small molecule activators of TRPML3. Chem Biol 17: 135-48 [PMID:20189104]

295. Grimm C, Kraft R, Sauerbruch S, Schultz G and Harteneck C. (2003) Molecular and functional characterization of the melastatin-related cation channel TRPM3. J Biol Chem 278: 21493-501 [PMID:12672799]

296. Grimm C, Kraft R, Schultz G and Harteneck C. (2005) Activation of the melastatin-related cation channel TRPM3 by D-erythro-sphingosine [corrected]. Mol Pharmacol 67: 798-805 [PMID:15550678]

297. Gross SA, Guzmán GA, Wissenbach U, Philipp SE, Zhu MX, Bruns D and Cavalié A. (2009) TRPC5 is a Ca2+-activated channel functionally coupled to Ca2+-selective ion channels. J Biol Chem 284: 34423-32 [PMID:19815560]

298. Grubisha O, Rafty LA, Takanishi CL, Xu X, Tong L, Perraud AL, Scharenberg AM and Denu JM. (2006) Metabolite of SIR2 reaction modulates TRPM2 ion channel. J Biol Chem 281: 14057-65 [PMID:16565078]

299. Guinamard R, Chatelier A, Demion M, Potreau D, Patri S, Rahmati M and Bois P. (2004) Functional characterization of a $\mathrm{Ca}(2+)$-activated non-selective cation channel in human atrial cardiomyocytes. J Physiol (Lond.) 558: 75-83 [PMID:15121803]

300. Guinamard R, Chatelier A, Lenfant J and Bois P. (2004) Activation of the Ca(2+)-activated nonselective cation channel by diacylglycerol analogues in rat cardiomyocytes. J Cardiovasc Electrophysiol 15: 342-8 [PMID:15030426]

301. Guinamard R, Sallé L and Simard C. (2011) The non-selective monovalent cationic channels TRPM4 and TRPM5. Adv Exp Med Biol 704: 147-71 [PMID:21290294]

302. Guler AD, Lee H, Iida T, Shimizu I, Tominaga M and Caterina M. (2002) Heat-evoked activation of the ion channel, TRPV4.J Neurosci 22: 6408-14 [PMID:12151520]

303. Gunthorpe MJ and Chizh BA. (2009) Clinical development of TRPV1 antagonists: targeting a pivotal point in the pain pathway. Drug Discov Today 14: 56-67 [PMID:19063991]

304. Gunthorpe MJ, Hannan SL, Smart D, Jerman JC, Arpino S, Smith GD, Brough S, Wright J, Egerton J and Lappin SC et al.. (2007) Characterization of SB-705498, a potent and selective vanilloid receptor-1 (VR1/TRPV1) antagonist that inhibits the capsaicin-, acid-, and heatmediated activation of the receptor. J Pharmacol Exp Ther 321: 1183-92 [PMID:17392405]

305. Gunthorpe MJ, Rami HK, Jerman JC, Smart D, Gill CH, Soffin EM, Luis Hannan S, Lappin SC, Egerton J and Smith GD et al. (2004) Identification and characterisation of SB-366791, a potent and selective vanilloid receptor (VR1/TRPV1) antagonist. Neuropharmacology 46: 133-49 [PMID:14654105] 
306. Guo L, Chen M, Basora N and Zhou J. (2000) The human polycystic kidney disease 2-like (PKDL) gene: exon/intron structure and evidence for a novel splicing mechanism. Mamm Genome 11: 46-50 [PMID:10602992]

307. Guo L, Schreiber TH, Weremowicz S, Morton CC, Lee C and Zhou J. (2000) Identification and characterization of a novel polycystin family member, polycystin-L2, in mouse and human: sequence, expression, alternative splicing, and chromosomal localization. Genomics 64: 241-51 [PMID:10756092]

308. Haas ET, Rowland K and Gautam M. (2011) Tooth injury increases expression of the cold sensitive TRP channel TRPA1 in trigeminal neurons. Arch Oral Biol 56: 1604-9 [PMID:21783172]

309. Halaszovich CR, Zitt C, Jungling E and Luckhoff A. (2000) Inhibition of TRP3 channels by lanthanides. Block from the cytosolic side of the plasma membrane. J Biol Chem 275: 37423-8 [PMID:10970899]

310. Hamanaka K, Jian MY, Weber DS, Alvarez DF, Townsley MI, Al-Mehdi AB, King JA, Liedtke W and Parker JC. (2007) TRPV4 initiates the acute calcium-dependent permeability increase during ventilator-induced lung injury in isolated mouse lungs. Am J Physiol Lung Cell Mol Physiol 293: L923-32 [PMID:17660328]

311. Han Q, Liu D, Convertino M, Wang Z, Jiang C, Kim YH, Luo X, Zhang X, Nackley A and Dokholyan NV et al.. (2018) miRNA-711 Binds and Activates TRPA1 Extracellularly to Evoke Acute and Chronic Pruritus. Neuron 99: 449-463.e6 [PMID:30033153]

312. Hanaoka K, Qian F, Boletta A, Bhunia AK, Piontek K, Tsiokas L, Sukhatme VP, Guggino WB and Germino GG. (2000) Co-assembly of polycystin-1 and -2 produces unique cation-permeable currents. Nature 408: 990-4 [PMID:11140688]

313. Hannan MA, Kabbani N, Paspalas CD and Levenson R. (2008) Interaction with dopamine D2 receptor enhances expression of transient receptor potential channel 1 at the cell surface. Biochim Biophys Acta 1778: 974-82 [PMID:18261457]

314. Hansen A and Finger TE. (2008) Is TrpM5 a reliable marker for chemosensory cells? Multiple types of microvillous cells in the main olfactory epithelium of mice. BMC Neurosci 9: 115 [PMID:19055837]

315. Hara Y, Wakamori M, Ishii M, Maeno E, Nishida M, Yoshida T, Yamada H, Shimizu S, Mori E and Kudoh J et al.. (2002) LTRPC2 Ca2+-permeable channel activated by changes in redox status confers susceptibility to cell death. Mol Cell 9: 163-73 [PMID:11804595]

316. Haraguchi K, Kawamoto A, Isami K, Maeda S, Kusano A, Asakura K, Shirakawa H, Mori Y, Nakagawa T and Kaneko S. (2012) TRPM2 contributes to inflammatory and neuropathic pain through the aggravation of pronociceptive inflammatory responses in mice. J Neurosci 32: 393141 [PMID:22423113]

317. Harding SD, Sharman JL, Faccenda E, Southan C, Pawson AJ, Ireland S, Gray AJG, Bruce L, Alexander SPH and Anderton S et al.. (2018) The IUPHAR/BPS Guide to PHARMACOLOGY in 2018: updates and expansion to encompass the new guide to IMMUNOPHARMACOLOGY. Nucleic Acids Res 46: D1091-D1106 [PMID:29149325]

318. Harteneck C. (2005) Function and pharmacology of TRPM cation channels. Naunyn Schmiedebergs Arch Pharmacol 371: 307-14 [PMID:15843919]

319. Harteneck C and Gollasch M. (2011) Pharmacological modulation of diacylglycerol-sensitive TRPC3/6/7 channels. Curr Pharm Biotechnol 12: 35-41 [PMID:20932261]

320. Hartmann J, Dragicevic E, Adelsberger H, Henning HA, Sumser M, Abramowitz J, Blum R, Dietrich A, Freichel M and Flockerzi V et al.. (2008) TRPC3 channels are required for synaptic transmission and motor coordination. Neuron 59: 392-8 [PMID:18701065]

321. Hata T, Tazawa S, Ohta S, Rhyu MR, Misaka T and Ichihara K. (2012) Artepillin C, a major ingredient of Brazilian propolis, induces a pungent taste by activating TRPA1 channels. PLoS ONE 7: e48072 [PMID:23133611]

322. Hatano N, Itoh Y, Suzuki H, Muraki Y, Hayashi H, Onozaki K, Wood IC, Beech DJ and Muraki K. (2012) Hypoxia-inducible factor-1 $\alpha$ (HIF1 $\alpha)$ switches on transient receptor potential ankyrin repeat 1 (TRPA1) gene expression via a hypoxia response element-like motif to modulate cytokine release. J Biol Chem 287: 31962-72 [PMID:22843691]

323. Hatano N, Suzuki H, Muraki Y and Muraki K. (2013) Stimulation of human TRPA1 channels by clinical concentrations of the antirheumatic drug auranofin. Am J Physiol, Cell Physiol 304: C354-61 [PMID:23220116]

324. Hayes P, Meadows HJ, Gunthorpe MJ, Harries MH, Duckworth DM, Cairns W, Harrison DC, Clarke CE, Ellington K and Prinjha RK et al.. (2000) Cloning and functional expression of a human orthologue of rat vanilloid receptor-1. Pain 88: 205-15 [PMID:11050376]

325. He LP, Hewavitharana T, Soboloff J, Spassova MA and Gill DL. (2005) A functional link between store-operated and TRPC channels revealed by the 3,5-bis(trifluoromethyl)pyrazole derivative, BTP2. J Biol Chem 280: 10997-1006 [PMID:15647288]

326. Heeringa SF, Möller CC, Du J, Yue L, Hinkes B, Chernin G, Vlangos CN, Hoyer PF, Reiser J and Hildebrandt F. (2009) A novel TRPC6 mutation that causes childhood FSGS. PLoS ONE 4: e7771 
[PMID:19936226]

327. Heiner I, Eisfeld J, Halaszovich CR, Wehage E, Jüngling E, Zitt C and Lückhoff A. (2003) Expression profile of the transient receptor potential (TRP) family in neutrophil granulocytes: evidence for currents through long TRP channel 2 induced by ADP-ribose and NAD. Biochem J 371: 1045-53 [PMID:12564954]

328. Held K, Kichko T, De Clercq K, Klaassen H, Van Bree R, Vanherck JC, Marchand A, Reeh PW, Chaltin P and Voets T et al.. (2015) Activation of TRPM3 by a potent synthetic ligand reveals a role in peptide release. Proc Natl Acad Sci USA 112: E1363-72 [PMID:25733887]

329. Hermosura MC, Cui AM, Go RC, Davenport B, Shetler CM, Heizer JW, Schmitz C, Mocz G, Garruto RM and Perraud AL. (2008) Altered functional properties of a TRPM2 variant in Guamanian ALS and PD. Proc Natl Acad Sci USA 105: 18029-34 [PMID:19004782]

330. Hermosura MC and Garruto RM. (2007) TRPM7 and TRPM2-Candidate susceptibility genes for Western Pacific ALS and PD? Biochim Biophys Acta 1772: 822-35 [PMID:17395433]

331. Hermosura MC, Nayakanti H, Dorovkov MV, Calderon FR, Ryazanov AG, Haymer DS and Garruto RM. (2005) A TRPM7 variant shows altered sensitivity to magnesium that may contribute to the pathogenesis of two Guamanian neurodegenerative disorders. Proc Natl Acad Sci USA 102: 11510-5 [PMID:16051700]

332. Herson PS, Dulock KA and Ashford ML. (1997) Characterization of a nicotinamide-adenine dinucleotide-dependent cation channel in the CRI-G1 rat insulinoma cell line. J Physiol (Lond.) 505 ( Pt 1): 65-76 [PMID:9409472]

333. Hill K, Benham CD, McNulty S and Randall AD. (2004) Flufenamic acid is a pH-dependent antagonist of TRPM2 channels. Neuropharmacology 47: 450-60 [PMID:15275834]

334. Hill K, McNulty S and Randall AD. (2004) Inhibition of TRPM2 channels by the antifungal agents clotrimazole and econazole. Naunyn Schmiedebergs Arch Pharmacol 370: 227-37 [PMID:15549272]

335. Hill K, Tigue NJ, Kelsell RE, Benham CD, McNulty S, Schaefer M and Randall AD. (2006) Characterisation of recombinant rat TRPM2 and a TRPM2-like conductance in cultured rat striatal neurones. Neuropharmacology 50: 89-97 [PMID:16260005]

336. Hinman A, Chuang HH, Bautista DM and Julius D. (2006) TRP channel activation by reversible covalent modification. Proc Natl Acad Sci USA 103: 19564-8 [PMID:17164327]

337. Hirnet D, Olausson J, Fecher-Trost C, Bödding M, Nastainczyk W, Wissenbach U, Flockerzi V and Freichel M. (2003) The TRPV6 gene, cDNA and protein. Cell Calcium 33: 509-18 [PMID:12765696]

338. Hiroi T, Wajima T, Negoro T, Ishii M, Nakano Y, Kiuchi Y, Mori Y and Shimizu S. (2013) Neutrophil TRPM2 channels are implicated in the exacerbation of myocardial ischaemia/reperfusion injury. Cardiovasc Res 97: 271-81 [PMID:23129587]

339. Hirschi M, Herzik Jr MA, Wie J, Suo Y, Borschel WF, Ren D, Lander GC and Lee SY. (2017) Cryoelectron microscopy structure of the lysosomal calcium-permeable channel TRPML3. Nature 550: 411-414 [PMID:29019979]

340. Hisanaga E, Nagasawa M, Ueki K, Kulkarni RN, Mori M and Kojima I. (2009) Regulation of calcium-permeable TRPV2 channel by insulin in pancreatic beta-cells. Diabetes 58: 174-84 [PMID:18984736]

341. Hoenderop JG, Müller D, Van Der Kemp AW, Hartog A, Suzuki M, Ishibashi K, Imai M, Sweep F, Willems PH and Van Os CH et al.. (2001) Calcitriol controls the epithelial calcium channel in kidney. J Am Soc Nephrol 12: 1342-9 [PMID:11423563]

342. Hoenderop JG, van Leeuwen JP, van der Eerden BC, Kersten FF, van der Kemp AW, MÃ@ rillat AM, Waarsing JH, Rossier BC, Vallon V, Hummler E and Bindels RJ. (2003) Renal Ca2+ wasting, hyperabsorption, and reduced bone thickness in mice lacking TRPV5. J Clin Invest 112: 1906-14 [PMID:14679186]

343. Hoenderop JG, Vennekens R, Müller D, Prenen J, Droogmans G, Bindels RJ and Nilius B. (2001) Function and expression of the epithelial $\mathrm{Ca}(2+)$ channel family: comparison of mammalian ECaC1 and 2.J Physiol (Lond.) 537: 747-61 [PMID:11744752]

344. Hoenderop JG, Voets T, Hoefs S, Weidema F, Prenen J, Nilius B and Bindels RJ. (2003) Homoand heterotetrameric architecture of the epithelial Ca2+ channels TRPV5 and TRPV6. EMBO J 22: 776-85 [PMID:12574114]

345. Hofherr A and Köttgen M. (2011) TRPP channels and polycystins. Adv Exp Med Biol 704: 287313 [PMID:21290302]

346. Hofmann T, Chubanov V, Gudermann T and Montell C. (2003) TRPM5 is a voltage-modulated and $\mathrm{Ca}(2+)$-activated monovalent selective cation channel. Curr Biol 13: 1153-8 [PMID:12842017]

347. Hofmann T, Obukhov AG, Schaefer M, Harteneck C, Gudermann T and Schultz G. (1999) Direct activation of human TRPC6 and TRPC3 channels by diacylglycerol. Nature 397: 259-63 [PMID:9930701]

348. Hofmann T, Schaefer M, Schultz G and Gudermann T. (2000) Cloning, expression and subcellular localization of two novel splice variants of mouse transient receptor potential 
channel 2. Biochem J 351: 115-22 [PMID:10998353]

349. Hofmann T, Schäfer S, Linseisen M, Sytik L, Gudermann T and Chubanov V. (2014) Activation of TRPM7 channels by small molecules under physiological conditions. Pflugers Arch 466: 2177-89 [PMID:24633576]

350. Holakovska B, Grycova L, Bily J and Teisinger J. (2011) Characterization of calmodulin binding domains in TRPV2 and TRPV5 C-tails. Amino Acids 40: 741-8 [PMID:20686800]

351. Hox V, Vanoirbeek JA, Alpizar YA, Voedisch S, Callebaut I, Bobic S, Sharify A, De Vooght V, Van Gerven L and Devos F et al.. (2013) Crucial role of transient receptor potential ankyrin 1 and mast cells in induction of nonallergic airway hyperreactivity in mice. Am J Respir Crit Care Med 187: 486-93 [PMID:23262517]

352. Hu H, Bandell M, Petrus MJ, Zhu MX and Patapoutian A. (2009) Zinc activates damage-sensing TRPA1 ion channels. Nat Chem Biol 5: 183-90 [PMID:19202543]

353. Hu H, Tian J, Zhu Y, Wang C, Xiao R, Herz JM, Wood JD and Zhu MX. (2010) Activation of TRPA1 channels by fenamate nonsteroidal anti-inflammatory drugs. Pflugers Arch 459: 579-92 [PMID:19888597]

354. Hu HZ, Gu Q, Wang C, Colton CK, Tang J, Kinoshita-Kawada M, Lee LY, Wood JD and Zhu MX. (2004) 2-aminoethoxydiphenyl borate is a common activator of TRPV1, TRPV2, and TRPV3.J Biol Chem 279: 35741-8 [PMID:15194687]

355. Huang AL, Chen X, Hoon MA, Chandrashekar J, Guo W, Tränkner D, Ryba NJ and Zuker CS. (2006) The cells and logic for mammalian sour taste detection. Nature 442: 934-8 [PMID:16929298]

356. Huang GN, Zeng W, Kim JY, Yuan JP, Han L, Muallem S and Worley PF. (2006) STIM1 carboxylterminus activates native SOC, I(crac) and TRPC1 channels. Nat Cell Biol 8: 1003-10 [PMID:16906149]

357. Huang SM, Lee H, Chung MK, Park U, Yu YY, Bradshaw HB, Coulombe PA, Walker JM and Caterina MJ. (2008) Overexpressed transient receptor potential vanilloid 3 ion channels in skin keratinocytes modulate pain sensitivity via prostaglandin E2. J Neurosci 28: 13727-37 [PMID:19091963]

358. Huang YA and Roper SD. (2010) Intracellular Ca(2+) and TRPM5-mediated membrane depolarization produce ATP secretion from taste receptor cells. J Physiol (Lond.) 588: 2343-50 [PMID:20498227]

359. Hui H, McHugh D, Hannan M, Zeng F, Xu SZ, Khan SU, Levenson R, Beech DJ and Weiss JL. (2006) Calcium-sensing mechanism in TRPC5 channels contributing to retardation of neurite outgrowth. J Physiol (Lond.) 572: 165-72 [PMID:16469785]

360. Hui K, Guo Y and Feng ZP. (2005) Biophysical properties of menthol-activated cold receptor TRPM8 channels. Biochem Biophys Res Commun 333: 374-82 [PMID:15950184]

361. Hunter JJ, Shao J, Smutko JS, Dussault BJ, Nagle DL, Woolf EA, Holmgren LM, Moore KJ and Shyjan AW. (1998) Chromosomal localization and genomic characterization of the mouse melastatin gene (Mlsn1). Genomics 54: 116-23 [PMID:9806836]

362. Hurne AM, Chai CL, Moerman K and Waring P. (2002) Influx of calcium through a redoxsensitive plasma membrane channel in thymocytes causes early necrotic cell death induced by the epipolythiodioxopiperazine toxins. J Biol Chem 277: 31631-8 [PMID:12063251]

363. Huynh KW, Cohen MR, Jiang J, Samanta A, Lodowski DT, Zhou ZH and Moiseenkova-Bell VY. (2016) Structure of the full-length TRPV2 channel by cryo-EM. Nat Commun 7: 11130 [PMID:27021073]

364. Hwang SW, Cho H, Kwak J, Lee SY, Kang CJ, Jung J, Cho S, Min KH, Suh YG and Kim D et al.. (2000) Direct activation of capsaicin receptors by products of lipoxygenases: endogenous capsaicin-like substances. Proc Natl Acad Sci USA 97: 6155-60 [PMID:10823958]

365. Häfner S, Burg F, Kannler M, Urban N, Mayer P, Dietrich A, Trauner D, Broichhagen J and Schaefer M. (2018) A (+)-Larixol Congener with High Affinity and Subtype Selectivity toward TRPC6. ChemMedChem 13: 1028-1035 [PMID:29522264]

366. Inada H, Iida T and Tominaga M. (2006) Different expression patterns of TRP genes in murine B and T lymphocytes. Biochem Biophys Res Commun 350: 762-7 [PMID:17027915]

367. Inoue R, Okada T, Onoue H, Hara Y, Shimizu S, Naitoh S, Ito Y and Mori Y. (2001) The transient receptor potential protein homologue TRP6 is the essential component of vascular alpha(1)adrenoceptor-activated $\mathrm{Ca}(2+)$-permeable cation channel. Circ Res 88: 325-32 [PMID:11179201]

368. Irie S and Furukawa T. (2014) TRPM1. Handb Exp Pharmacol 222: 387-402 [PMID:24756714]

369. Irnaten M, Blanchard-Gutton N, Praetorius J and Harvey BJ. (2009) Rapid effects of 17betaestradiol on TRPV5 epithelial Ca2 + channels in rat renal cells. Steroids 74: 642-9 [PMID:19463684]

370. Ishimaru $Y$, Inada $H$, Kubota $M$, Zhuang H, Tominaga M and Matsunami H. (2006) Transient receptor potential family members PKD1L3 and PKD2L1 form a candidate sour taste receptor. Proc Natl Acad Sci USA 103: 12569-74 [PMID:16891422]

371. Islam MS. (2011) TRP channels of islets. Adv Exp Med Biol 704: 811-30 [PMID:21290328] 
372. Iwata Y, Katanosaka Y, Arai Y, Komamura K, Miyatake K and Shigekawa M. (2003) A novel mechanism of myocyte degeneration involving the Ca2+-permeable growth factor-regulated channel. J Cell Biol 161: 957-67 [PMID:12796481]

373. Iwata Y, Katanosaka Y, Arai Y, Shigekawa M and Wakabayashi S. (2009) Dominant-negative inhibition of Ca2+ influx via TRPV2 ameliorates muscular dystrophy in animal models. Hum Mol Genet 18: 824-34 [PMID:19050039]

374. Jacobs G, Oosterlinck W, Dresselaers T, Geenens R, Kerselaers S, Himmelreich U, Herijgers P and Vennekens R. (2015) Enhanced $\beta$-adrenergic cardiac reserve in Trpm $4^{-{ }^{-}}$mice with ischaemic heart failure. Cardiovasc Res 105: 330-9 [PMID:25600961]

375. Jang Y, Lee Y, Kim SM, Yang YD, Jung J and Oh U. (2012) Quantitative analysis of TRP channel genes in mouse organs. Arch Pharm Res 35: 1823-30 [PMID:23139135]

376. Janssen SW, Hoenderop JG, Hermus AR, Sweep FC, Martens GJ and Bindels RJ. (2002) Expression of the novel epithelial $\mathrm{Ca} 2+$ channel ECaC1 in rat pancreatic islets. $J$ Histochem Cytochem 50: 789-98 [PMID:12019295]

377. Jaquemar D, Schenker T and Trueb B. (1999) An ankyrin-like protein with transmembrane domains is specifically lost after oncogenic transformation of human fibroblasts. J Biol Chem 274: 7325-33 [PMID:10066796]

378. Jeon JP, Hong C, Park EJ, Jeon JH, Cho NH, Kim IG, Choe H, Muallem S, Kim HJ and So I. (2012) Selective Goi subunits as novel direct activators of transient receptor potential canonical (TRPC)4 and TRPC5 channels. J Biol Chem 287: 17029-39 [PMID:22457348]

379. Jerman JC, Brough SJ, Prinjha R, Harries MH, Davis JB and Smart D. (2000) Characterization using FLIPR of rat vanilloid receptor (rVR1) pharmacology. Br J Pharmacol 130: 916-22 [PMID:10864900]

380. Jiang J, Li M and Yue L. (2005) Potentiation of TRPM7 inward currents by protons. J Gen Physiol 126: $137-50$ [PMID:16009728]

381. Jin J, Desai BN, Navarro B, Donovan A, Andrews NC and Clapham DE. (2008) Deletion of Trpm7 disrupts embryonic development and thymopoiesis without altering Mg2+ homeostasis. Science 322: 756-60 [PMID:18974357]

382. Jordt SE, Bautista DM, Chuang HH, McKemy DD, Zygmunt PM, Högestätt ED, Meng ID and Julius D. (2004) Mustard oils and cannabinoids excite sensory nerve fibres through the TRP channel ANKTM1. Nature 427: 260-5 [PMID:14712238]

383. Jung S, Mühle A, Schaefer M, Strotmann R, Schultz G and Plant TD. (2003) Lanthanides potentiate TRPC5 currents by an action at extracellular sites close to the pore mouth. J Biol Chem 278: 3562-71 [PMID:12456670]

384. Just S, Chenard BL, Ceci A, Strassmaier T, Chong JA, Blair NT, Gallaschun RJ, Del Camino D, Cantin S and D'Amours M et al.. (2018) Treatment with HC-070, a potent inhibitor of TRPC4 and TRPC5, leads to anxiolytic and antidepressant effects in mice. PLoS ONE 13: e0191225 [PMID:29385160]

385. Juvin V, Penna A, Chemin J, Lin YL and Rassendren FA. (2007) Pharmacological characterization and molecular determinants of the activation of transient receptor potential V2 channel orthologs by 2-aminoethoxydiphenyl borate. Mol Pharmacol 72: 1258-68 [PMID:17673572]

386. Kaczmarek JS, Riccio A and Clapham DE. (2012) Calpain cleaves and activates the TRPC5 channel to participate in semaphorin 3A-induced neuronal growth cone collapse. Proc Natl Acad Sci USA 109: 7888-92 [PMID:22547824]

387. Kajiya H, Okamoto F, Nemoto T, Kimachi K, Toh-Goto K, Nakayana S and Okabe K. (2010) RANKL-induced TRPV2 expression regulates osteoclastogenesis via calcium oscillations. Cell Calcium 48: 260-9 [PMID:20980052]

388. Kaneko S, Kawakami S, Hara Y, Wakamori M, Itoh E, Minami T, Takada Y, Kume T, Katsuki H and Mori Y et al.. (2006) A critical role of TRPM2 in neuronal cell death by hydrogen peroxide. $J$ Pharmacol Sci 101: 66-76 [PMID:16651700]

389. Kanzaki M, Zhang YQ, Mashima H, Li L, Shibata H and Kojima I. (1999) Translocation of a calcium-permeable cation channel induced by insulin-like growth factor-I. Nat Cell Biol 1: 165 70 [PMID:10559903]

390. Karacsonyi C, Miguel AS and Puertollano R. (2007) Mucolipin-2 localizes to the Arf6-associated pathway and regulates recycling of GPI-APs. Traffic 8: 1404-14 [PMID:17662026]

391. Karashima Y, Damann N, Prenen J, Talavera K, Segal A, Voets T and Nilius B. (2007) Bimodal action of menthol on the transient receptor potential channel TRPA1. J Neurosci 27: 9874-84 [PMID:17855602]

392. Karashima Y, Talavera K, Everaerts W, Janssens A, Kwan KY, Vennekens R, Nilius B and Voets T. (2009) TRPA1 acts as a cold sensor in vitro and in vivo. Proc Natl Acad Sci USA 106: 1273-8 [PMID:19144922]

393. Kashio M, Sokabe T, Shintaku K, Uematsu T, Fukuta N, Kobayashi N, Mori Y and Tominaga M. (2012) Redox signal-mediated sensitization of transient receptor potential melastatin 2 (TRPM2) to temperature affects macrophage functions. Proc Natl Acad Sci USA 109: 6745-50 [PMID:22493272] 
394. Katano M, Numata T, Aguan K, Hara Y, Kiyonaka S, Yamamoto S, Miki T, Sawamura S, Suzuki T and Yamakawa K et al.. (2012) The juvenile myoclonic epilepsy-related protein EFHC1 interacts with the redox-sensitive TRPM2 channel linked to cell death. Cell Calcium 51: 179-85 [PMID:22226147]

395. Kato AS, Knierman MD, Siuda ER, Isaac JT, Nisenbaum ES and Bredt DS. (2012) Glutamate receptor $\delta 2$ associates with metabotropic glutamate receptor 1 (mGluR1), protein kinase $\mathrm{C} \gamma$, and canonical transient receptor potential 3 and regulates mGluR1-mediated synaptic transmission in cerebellar Purkinje neurons. J Neurosci 32: 15296-308 [PMID:23115168]

396. Katsura H, Obata K, Mizushima T, Sakurai J, Kobayashi K, Yamanaka H, Dai Y, Fukuoka T, Sakagami M and Noguchi K. (2007) Activation of extracellular signal-regulated protein kinases 5 in primary afferent neurons contributes to heat and cold hyperalgesia after inflammation. $J$ Neurochem 102: 1614-24 [PMID:17573825]

397. Katsura H, Obata K, Mizushima T, Yamanaka H, Kobayashi K, Dai Y, Fukuoka T, Tokunaga A, Sakagami M and Noguchi K. (2006) Antisense knock down of TRPA1, but not TRPM8, alleviates cold hyperalgesia after spinal nerve ligation in rats. Exp Neurol 200: 112-23 [PMID:16546170]

398. Kawashima Y, Géléoc GS, Kurima K, Labay V, Lelli A, Asai Y, Makishima T, Wu DK, Della Santina CC and Holt JR et al.. (2011) Mechanotransduction in mouse inner ear hair cells requires transmembrane channel-like genes. J Clin Invest 121: 4796-809 [PMID:22105175]

399. Kerschbaum HH, Kozak JA and Cahalan MD. (2003) Polyvalent cations as permeant probes of MIC and TRPM7 pores. Biophys J 84: 2293-305 [PMID:12668438]

400. Khairatkar-Joshi N, Shah DM, Mukhopadhyay I, Lingam VS and Thomas A. (2015) TRPC channel modulators and their potential therapeutic applications. Pharm Pat Anal 4: 207-18 [PMID:26030081]

401. Kim HJ, Li Q, Tjon-Kon-Sang S, So I, Kiselyov K and Muallem S. (2007) Gain-of-function mutation in TRPML3 causes the mouse Varitint-Waddler phenotype. J Biol Chem 282: 36138-42 [PMID:17962195]

402. Kim HJ, Li Q, Tjon-Kon-Sang S, So I, Kiselyov K, Soyombo AA and Muallem S. (2008) A novel mode of TRPML3 regulation by extracytosolic $\mathrm{pH}$ absent in the varitint-waddler phenotype. EMBO J 27: 1197-205 [PMID:18369318]

403. Kim HJ, Soyombo AA, Tjon-Kon-Sang S, So I and Muallem S. (2009) The Ca(2+) channel TRPML3 regulates membrane trafficking and autophagy. Traffic 10: 1157-67 [PMID:19522758]

404. Kim S-Y, Kim JK, Lee K-W, Woo BY, Shin SS, Moh J-H, Kim S-il, Jeong YS, Lim KM and Choi JK et al.. (2010) Compounds, isomer thereof, or pharmaceutically acceptable salts thereof as vanilloid receptor antagonist; and pharmaceutical compositions containing the same Patent number: US7858621.

405. Kim SJ, Kim YS, Yuan JP, Petralia RS, Worley PF and Linden DJ. (2003) Activation of the TRPC1 cation channel by metabotropic glutamate receptor mGluR1. Nature 426: 285-91 [PMID:14614461]

406. Kim W, Bennett EJ, Huttlin EL, Guo A, Li J, Possemato A, Sowa ME, Rad R, Rush J and Comb MJ et al.. (2011) Systematic and quantitative assessment of the ubiquitin-modified proteome. Mol Cell 44: 325-40 [PMID:21906983]

407. Kim YS, Kang E, Makino Y, Park S, Shin JH, Song H, Launay P and Linden DJ. (2013) Characterizing the conductance underlying depolarization-induced slow current in cerebellar Purkinje cells. J Neurophysiol 109: 1174-81 [PMID:23197456]

408. Kimball ES, Prouty SP, Pavlick KP, Wallace NH, Schneider CR and Hornby PJ. (2007) Stimulation of neuronal receptors, neuropeptides and cytokines during experimental oil of mustard colitis. Neurogastroenterol Motil 19: 390-400 [PMID:17509021]

409. Kinoshita-Kawada M, Tang J, Xiao R, Kaneko S, Foskett JK and Zhu MX. (2005) Inhibition of TRPC5 channels by Ca2+-binding protein 1 in Xenopus oocytes. Pflugers Arch 450: 345-54 [PMID:15895247]

410. Kiselyov K and Patterson RL. (2009) The integrative function of TRPC channels. Front Biosci 14: 45-58 [PMID:19273053]

411. Kiselyov K, Shin DM, Kim JY, Yuan JP and Muallem S. (2007) TRPC channels: interacting proteins. Handb Exp Pharmacol: 559-74 [PMID:17217079]

412. Kiselyov K, Soyombo A and Muallem S. (2007) TRPpathies. J Physiol (Lond.) 578: 641-53 [PMID:17138610]

413. Kitaguchi T and Swartz KJ. (2005) An inhibitor of TRPV1 channels isolated from funnel Web spider venom. Biochemistry 44: 15544-9 [PMID:16300403]

414. Kittaka H, Yamanoi Y and Tominaga M. (2017) Transient receptor potential vanilloid 4 (TRPV4) channel as a target of crotamiton and its bimodal effects. Pflugers Arch 469: 1313-1323 [PMID:28612138]

415. Kiyonaka S, Kato K, Nishida M, Mio K, Numaga T, Sawaguchi Y, Yoshida T, Wakamori M, Mori E and Numata T et al.. (2009) Selective and direct inhibition of TRPC3 channels underlies biological activities of a pyrazole compound. Proc Natl Acad Sci USA 106: 5400-5 [PMID:19289841] 
416. Klausen TK, Pagani A, Minassi A, Ech-Chahad A, Prenen J, Owsianik G, Hoffmann EK, Pedersen SF, Appendino G and Nilius B. (2009) Modulation of the transient receptor potential vanilloid channel TRPV4 by 4alpha-phorbol esters: a structure-activity study. J Med Chem 52: 2933-9 [PMID:19361196]

417. Klooster J, Blokker J, Ten Brink JB, Unmehopa U, Fluiter K, Bergen AA and Kamermans M. (2011) Ultrastructural localization and expression of TRPM1 in the human retina. Invest Ophthalmol Vis Sci 52: 8356-62 [PMID:21896854]

418. Klose C, Straub I, Riehle M, Ranta F, Krautwurst D, Ullrich S, Meyerhof W and Harteneck C. (2011) Fenamates as TRP channel blockers: mefenamic acid selectively blocks TRPM3. $\mathrm{BrJ}$ Pharmacol 162: 1757-69 [PMID:21198543]

419. Knowlton WM, Daniels RL, Palkar R, McCoy DD and McKemy DD. (2011) Pharmacological blockade of TRPM8 ion channels alters cold and cold pain responses in mice. PLoS ONE 6: e25894 [PMID:21984952]

420. Knowlton WM and McKemy DD. (2011) TRPM8: from cold to cancer, peppermint to pain. Curr Pharm Biotechnol 12: 68-77 [PMID:20932257]

421. Kobayashi K, Fukuoka T, Obata K, Yamanaka H, Dai Y, Tokunaga A and Noguchi K. (2005) Distinct expression of TRPM8, TRPA1, and TRPV1 mRNAs in rat primary afferent neurons with adelta/c-fibers and colocalization with trk receptors. J Comp Neurol 493: 596-606 [PMID:16304633]

422. Kobori T, Smith GD, Sandford R and Edwardson JM. (2009) The transient receptor potential channels TRPP2 and TRPC1 form a heterotetramer with a 2:2 stoichiometry and an alternating subunit arrangement. J Biol Chem 284: 35507-13 [PMID:19850920]

423. Koch SE, Gao X, Haar L, Jiang M, Lasko VM, Robbins N, Cai W, Brokamp C, Varma P and Tranter M et al.. (2012) Probenecid: novel use as a non-injurious positive inotrope acting via cardiac TRPV2 stimulation. J Mol Cell Cardiol 53: 134-44 [PMID:22561103]

424. Kochukov MY, Balasubramanian A, Noel RC and Marrelli SP. (2013) Role of TRPC1 and TRPC3 channels in contraction and relaxation of mouse thoracic aorta. J Vasc Res 50: 11-20 [PMID:23095462]

425. Koike C, Obara T, Uriu Y, Numata T, Sanuki R, Miyata K, Koyasu T, Ueno S, Funabiki K and Tani A et al.. (2010) TRPM1 is a component of the retinal ON bipolar cell transduction channel in the mGluR6 cascade. Proc Natl Acad Sci USA 107: 332-7 [PMID:19966281]

426. Koivisto A, Hukkanen M, Saarnilehto M, Chapman H, Kuokkanen K, Wei H, Viisanen H, Akerman KE, Lindstedt K and Pertovaara A. (2012) Inhibiting TRPA1 ion channel reduces loss of cutaneous nerve fiber function in diabetic animals: sustained activation of the TRPA1 channel contributes to the pathogenesis of peripheral diabetic neuropathy. Pharmacol Res 65: 149-58 [PMID:22133672]

427. Kojima R, Nozawa K, Doihara H, Keto Y, Kaku H, Yokoyama T and Itou H. (2014) Effects of novel TRPA1 receptor agonist ASP7663 in models of drug-induced constipation and visceral pain. Eur J Pharmacol 723: 288-93 [PMID:24291101]

428. Kolisek M, Beck A, Fleig A and Penner R. (2005) Cyclic ADP-ribose and hydrogen peroxide synergize with ADP-ribose in the activation of TRPM2 channels. Mol Cell 18: 61-9 [PMID:15808509]

429. Kondo M, Sanuki R, Ueno S, Nishizawa Y, Hashimoto N, Ohguro H, Yamamoto S, Machida S, Terasaki $\mathrm{H}$ and Adamus G et al.. (2011) Identification of autoantibodies against TRPM1 in patients with paraneoplastic retinopathy associated with ON bipolar cell dysfunction. PLOS ONE 6: e19911 [PMID:21611200]

430. Kono T, Kaneko A, Omiya Y, Ohbuchi K, Ohno N and Yamamoto M. (2013) Epithelial transient receptor potential ankyrin 1 (TRPA1)-dependent adrenomedullin upregulates blood flow in rat small intestine. Am J Physiol Gastrointest Liver Physiol 304: G428-36 [PMID:23275609]

431. Kosugi M, Nakatsuka T, Fujita T, Kuroda Y and Kumamoto E. (2007) Activation of TRPA1 channel facilitates excitatory synaptic transmission in substantia gelatinosa neurons of the adult rat spinal cord. J Neurosci 27: 4443-51 [PMID:17442829]

432. Koulen P, Cai Y, Geng L, Maeda Y, Nishimura S, Witzgall R, Ehrlich BE and Somlo S. (2002) Polycystin-2 is an intracellular calcium release channel. Nat Cell Biol 4: 191-7 [PMID:11854751]

433. Kozak JA, Kerschbaum HH and Cahalan MD. (2002) Distinct properties of CRAC and MIC channels in RBL cells. J Gen Physiol 120: 221-35 [PMID:12149283]

434. Kozak JA, Matsushita M, Nairn AC and Cahalan MD. (2005) Charge screening by internal pH and polyvalent cations as a mechanism for activation, inhibition, and rundown of TRPM7/MIC channels. J Gen Physiol 126: 499-514 [PMID:16260839]

435. Kraft R. (2007) The Na+/Ca2+ exchange inhibitor KB-R7943 potently blocks TRPC channels. Biochem Biophys Res Commun 361: 230-6 [PMID:17658472]

436. Kraft R, Grimm C, Frenzel H and Harteneck C. (2006) Inhibition of TRPM2 cation channels by $\mathrm{N}$-(p-amylcinnamoyl)anthranilic acid. Br J Pharmacol 148: 264-73 [PMID:16604090]

437. Kraft R, Grimm C, Grosse K, Hoffmann A, Sauerbruch S, Kettenmann H, Schultz G and Harteneck C. (2004) Hydrogen peroxide and ADP-ribose induce TRPM2-mediated calcium influx 
and cation currents in microglia. Am J Physiol, Cell Physiol 286: C129-37 [PMID:14512294]

438. Kraft R and Harteneck C. (2005) The mammalian melastatin-related transient receptor potential cation channels: an overview. Pflugers Arch 451: 204-11 [PMID:15895246]

439. Krakow D, Vriens J, Camacho N, Luong P, Deixler H, Funari TL, Bacino CA, Irons MB, Holm IA and Sadler L et al.. (2009) Mutations in the gene encoding the calcium-permeable ion channel TRPV4 produce spondylometaphyseal dysplasia, Kozlowski type and metatropic dysplasia. Am J Hum Genet 84: 307-15 [PMID:19232556]

440. Krapivinsky G, Mochida S, Krapivinsky L, Cibulsky SM and Clapham DE. (2006) The TRPM7 ion channel functions in cholinergic synaptic vesicles and affects transmitter release. Neuron 52: 485-96 [PMID:17088214]

441. Kremeyer B, Lopera F, Cox JJ, Momin A, Rugiero F, Marsh S, Woods CG, Jones NG, Paterson KJ and Fricker FR et al.. (2010) A gain-of-function mutation in TRPA1 causes familial episodic pain syndrome. Neuron 66: 671-80 [PMID:20547126]

442. Krügel U, Straub I, Beckmann H and Schaefer M. (2017) Primidone inhibits TRPM3 and attenuates thermal nociception in vivo. Pain 158: 856-867 [PMID:28106668]

443. Kudoh J, Nagamine K, Asakawa S, Abe I, Kawasaki K, Maeda H, Tsujimoto S, Minoshima S, Ito F and Shimizu N. (1997) Localization of 16 exons to a 450-kb region involved in the autoimmune polyglandular disease type I (APECED) on human chromosome 21q22.3. DNA Res 4: 45-52 [PMID:9179495]

444. Kun J, Perkecz A, Knie L, Sétáló Jr G, Tornóczki T, Pintér E and Bán Á. (2017) TRPA1 receptor is upregulated in human oral lichen planus. Oral Dis 23: 189-198 [PMID:27718297]

445. Kunert-Keil C, Bisping F, Krüger J and Brinkmeier H. (2006) Tissue-specific expression of TRP channel genes in the mouse and its variation in three different mouse strains. BMC Genomics 7: 159 [PMID:16787531]

446. Kunkler PE, Ballard CJ, Oxford GS and Hurley JH. (2011) TRPA1 receptors mediate environmental irritant-induced meningeal vasodilatation. Pain 152: 38-44 [PMID:21075522]

447. Kuras Z, Yun YH, Chimote AA, Neumeier L and Conforti L. (2012) KCa3.1 and TRPM7 channels at the uropod regulate migration of activated human T cells. PLOS ONE 7: e43859 [PMID:22952790]

448. Kusudo T, Wang Z, Mizuno A, Suzuki M and Yamashita H. (2012) TRPV4 deficiency increases skeletal muscle metabolic capacity and resistance against diet-induced obesity. J Appl Physiol 112: 1223-32 [PMID:22207724]

449. Kwan KY, Allchorne AJ, Vollrath MA, Christensen AP, Zhang DS, Woolf CJ and Corey DP. (2006) TRPA1 contributes to cold, mechanical, and chemical nociception but is not essential for haircell transduction. Neuron 50: 277-89 [PMID:16630838]

450. Kwan KY, Glazer JM, Corey DP, Rice FL and Stucky CL. (2009) TRPA1 modulates mechanotransduction in cutaneous sensory neurons. J Neurosci 29: 4808-19 [PMID:19369549]

451. Kühn FJ, Heiner I and Lückhoff A. (2005) TRPM2: a calcium influx pathway regulated by oxidative stress and the novel second messenger ADP-ribose. Pflugers Arch 451: 212-9 [PMID:15952035]

452. Lainez S, Schlingmann KP, van der Wijst J, Dworniczak B, van Zeeland F, Konrad M, Bindels RJ and Hoenderop JG. (2014) New TRPM6 missense mutations linked to hypomagnesemia with secondary hypocalcemia. Eur J Hum Genet 22: 497-504 [PMID:23942199]

453. Lamandé SR, Yuan Y, Gresshoff IL, Rowley L, Belluoccio D, Kaluarachchi K, Little CB, Botzenhart E, Zerres K and Amor DJ et al.. (2011) Mutations in TRPV4 cause an inherited arthropathy of hands and feet. Nat Genet 43: 1142-6 [PMID:21964574]

454. Lambers TT, Mahieu F, Oancea E, Hoofd L, de Lange F, Mensenkamp AR, Voets T, Nilius B, Clapham DE and Hoenderop JG et al.. (2006) Calbindin-D28K dynamically controls TRPV5mediated Ca2+ transport. EMBO J 25: 2978-88 [PMID:16763551]

455. Lambers TT, Weidema AF, Nilius B, Hoenderop JG and Bindels RJ. (2004) Regulation of the mouse epithelial $\mathrm{Ca} 2(+)$ channel TRPV6 by the $\mathrm{Ca}(2+)$-sensor calmodulin. J Biol Chem 279: 28855-61 [PMID:15123711]

456. Lambert S, Drews A, Rizun O, Wagner TF, Lis A, Mannebach S, Plant S, Portz M, Meissner M and Philipp SE et al.. (2011) Transient receptor potential melastatin 1 (TRPM1) is an ionconducting plasma membrane channel inhibited by zinc ions. J Biol Chem 286: 12221-33 [PMID:21278253]

457. Landouré G, Zdebik AA, Martinez TL, Burnett BG, Stanescu HC, Inada H, Shi Y, Taye AA, Kong L and Munns CH et al.. (2010) Mutations in TRPV4 cause Charcot-Marie-Tooth disease type 2C. Nat Genet 42: 170-4 [PMID:20037586]

458. Lange I, Penner R, Fleig A and Beck A. (2008) Synergistic regulation of endogenous TRPM2 channels by adenine dinucleotides in primary human neutrophils. Cell Calcium 44: 604-15 [PMID:18572241]

459. Lange I, Yamamoto S, Partida-Sanchez S, Mori Y, Fleig A and Penner R. (2009) TRPM2 functions as a lysosomal Ca2+-release channel in beta cells. Sci Signal 2: ra23 [PMID:19454650]

460. LaPlante JM, Falardeau J, Sun M, Kanazirska M, Brown EM, Slaugenhaupt SA and Vassilev PM. 
(2002) Identification and characterization of the single channel function of human mucolipin-1 implicated in mucolipidosis type IV, a disorder affecting the lysosomal pathway. FEBS Lett $\mathbf{5 3 2}$ 183-7 [PMID:12459486]

461. LaPlante JM, Sun M, Falardeau J, Dai D, Brown EM, Slaugenhaupt SA and Vassilev PM. (2006) Lysosomal exocytosis is impaired in mucolipidosis type IV. Mol Genet Metab 89: 339-48 [PMID:16914343]

462. LaPlante JM, Ye CP, Quinn SJ, Goldin E, Brown EM, Slaugenhaupt SA and Vassilev PM. (2004) Functional links between mucolipin-1 and Ca2+-dependent membrane trafficking in mucolipidosis IV. Biochem Biophys Res Commun 322: 1384-91 [PMID:15336987]

463. Lashinger ES, Steiginga MS, Hieble JP, Leon LA, Gardner SD, Nagilla R, Davenport EA, Hoffman BE, Laping NJ and Su X. (2008) AMTB, a TRPM8 channel blocker: evidence in rats for activity in overactive bladder and painful bladder syndrome. Am J Physiol Renal Physiol 295: F803-10 [PMID:18562636]

464. Launay P, Cheng H, Srivatsan S, Penner R, Fleig A and Kinet JP. (2004) TRPM4 regulates calcium oscillations after T cell activation. Science 306: 1374-7 [PMID:15550671]

465. Launay P, Fleig A, Perraud AL, Scharenberg AM, Penner R and Kinet JP. (2002) TRPM4 is a Ca2+-activated nonselective cation channel mediating cell membrane depolarization. Cell 109: 397-407 [PMID:12015988]

466. Lee KP, Jun JY, Chang IY, Suh SH, So I and Kim KW. (2005) TRPC4 is an essential component of the nonselective cation channel activated by muscarinic stimulation in mouse visceral smooth muscle cells. Mol Cells 20: 435-41 [PMID:16404161]

467. Lee N, Chen J, Sun L, Wu S, Gray KR, Rich A, Huang M, Lin JH, Feder JN and Janovitz EB et al.. (2003) Expression and characterization of human transient receptor potential melastatin 3 (hTRPM3). J Biol Chem 278: 20890-7 [PMID:12672827]

468. Lee SP, Buber MT, Yang Q, Cerne R, Cortés RY, Sprous DG and Bryant RW. (2008) Thymol and related alkyl phenols activate the hTRPA1 channel. BrJ Pharmacol 153: 1739-49 [PMID:18334983]

469. Lee YM, Kim BJ, Kim HJ, Yang DK, Zhu MH, Lee KP, So I and Kim KW. (2003) TRPC5 as a candidate for the nonselective cation channel activated by muscarinic stimulation in murine stomach. Am J Physiol Gastrointest Liver Physiol 284: G604-16 [PMID:12631560]

470. Leffler A, Lattrell A, Kronewald S, Niedermirtl F and Nau C. (2011) Activation of TRPA1 by membrane permeable local anesthetics. Mol Pain 7: 62 [PMID:21861907]

471. Lei YT, Thuault SJ, Launay P, Margolskee RF, Kandel ER and Siegelbaum SA. (2014) Differential contribution of TRPM4 and TRPM5 nonselective cation channels to the slow afterdepolarization in mouse prefrontal cortex neurons. Front Cell Neurosci 8: 267 [PMID:25237295]

472. Leonelli M, Martins DO, Kihara AH and Britto LR. (2009) Ontogenetic expression of the vanilloid receptors TRPV1 and TRPV2 in the rat retina. Int J Dev Neurosci 27: 709-18 [PMID:19619635]

473. Leuner K, Heiser JH, Derksen S, Mladenov MI, Fehske CJ, Schubert R, Gollasch M, Schneider G, Harteneck C and Chatterjee SS et al.. (2010) Simple 2,4-diacylphloroglucinols as classic transient receptor potential-6 activators--identification of a novel pharmacophore. $\mathrm{Mol}$ Pharmacol 77: 368-77 [PMID:20008516]

474. Leuner K, Kazanski V, Müller M, Essin K, Henke B, Gollasch M, Harteneck C and Müller WE. (2007) Hyperforin--a key constituent of St. John's wort specifically activates TRPC6 channels. FASEB J 21: 4101-11 [PMID:17666455]

475. Lev S, Zeevi DA, Frumkin A, Offen-Glasner V, Bach G and Minke B. (2010) Constitutive activity of the human TRPML2 channel induces cell degeneration. J Biol Chem 285: 2771-82 [PMID:19940139]

476. Levina N, Tötemeyer S, Stokes NR, Louis P, Jones MA and Booth IR. (1999) Protection of Escherichia coli cells against extreme turgor by activation of MscS and MscL mechanosensitive channels: identification of genes required for MscS activity. EMBO J 18: 1730-7 [PMID:10202137]

477. Lewinter RD, Skinner K, Julius D and Basbaum AI. (2004) Immunoreactive TRPV-2 (VRL-1), a capsaicin receptor homolog, in the spinal cord of the rat. J Comp Neurol 470: 400-8 [PMID:14961565]

478. Leypold BG, Yu CR, Leinders-Zufall T, Kim MM, Zufall F and Axel R. (2002) Altered sexual and social behaviors in trp2 mutant mice. Proc Natl Acad Sci U S A 99: 6376-81 [PMID:11972034]

479. Li HS, Xu XZ and Montell C. (1999) Activation of a TRPC3-dependent cation current through the neurotrophin BDNF. Neuron 24: 261-73 [PMID:10677043]

480. Li M, Jiang J and Yue L. (2006) Functional characterization of homo- and heteromeric channel kinases TRPM6 and TRPM7. J Gen Physiol 127: 525-37 [PMID:16636202]

481. Li Q, Dai Y, Guo L, Liu Y, Hao C, Wu G, Basora N, Michalak M and Chen XZ. (2003) Polycystin-2 associates with tropomyosin-1, an actin microfilament component. J Mol Biol 325: 949-62 [PMID:12527301]

482. Li Q, Montalbetti N, Shen PY, Dai XQ, Cheeseman CI, Karpinski E, Wu G, Cantiello HF and Chen XZ. (2005) Alpha-actinin associates with polycystin-2 and regulates its channel activity. Hum 
Mol Genet 14: 1587-603 [PMID:15843396]

483. Li Q, Shen PY, Wu G and Chen XZ. (2003) Polycystin-2 interacts with troponin I, an angiogenesis inhibitor. Biochemistry 42: 450-7 [PMID:12525172]

484. Li X, Luo Y, Starremans PG, McNamara CA, Pei Y and Zhou J. (2005) Polycystin-1 and polycystin-2 regulate the cell cycle through the helix-loop-helix inhibitor Id2. Nat Cell Biol 7: 1202-12 [PMID:16311606]

485. Li Y, Jia YC, Cui K, Li N, Zheng ZY, Wang YZ and Yuan XB. (2005) Essential role of TRPC channels in the guidance of nerve growth cones by brain-derived neurotrophic factor. Nature 434: 894-8 [PMID:15758952]

486. Li Y, Wright JM, Qian F, Germino GG and Guggino WB. (2005) Polycystin 2 interacts with type I inositol 1,4,5-trisphosphate receptor to modulate intracellular Ca2+ signaling. J Biol Chem 280: 41298-306 [PMID:16223735]

487. Li Z, Sergouniotis PI, Michaelides M, Mackay DS, Wright GA, Devery S, Moore AT, Holder GE, Robson AG and Webster AR. (2009) Recessive mutations of the gene TRPM1 abrogate ON bipolar cell function and cause complete congenital stationary night blindness in humans. Am J Hum Genet 85: 711-9 [PMID:19878917]

488. Liao M, Cao E, Julius D and Cheng Y. (2013) Structure of the TRPV1 ion channel determined by electron cryo-microscopy. Nature 504: 107-12 [PMID:24305160]

489. Liapi A and Wood JN. (2005) Extensive co-localization and heteromultimer formation of the vanilloid receptor-like protein TRPV2 and the capsaicin receptor TRPV1 in the adult rat cerebral cortex. Eur J Neurosci 22: 825-34 [PMID:16115206]

490. Liedtke W, Choe Y, Martí-Renom MA, Bell AM, Denis CS, Sali A, Hudspeth AJ, Friedman JM and Heller S. (2000) Vanilloid receptor-related osmotically activated channel (VR-OAC), a candidate vertebrate osmoreceptor. Cell 103: 525-35 [PMID:11081638]

491. Liedtke WB, Heller S, Latorre R, Vargas G, Orta G and Brauchi S. (2007) Voltage and Temperature Gating of ThermoTRP Channels. Frontiers in Neuroscience [PMID:21204490]

492. Lievremont JP, Bird GS and Putney Jr JW. (2005) Mechanism of inhibition of TRPC cation channels by 2-aminoethoxydiphenylborane. Mol Pharmacol 68: 758-62 [PMID:15933213]

493. Lievremont JP, Numaga T, Vazquez G, Lemonnier L, Hara Y, Mori E, Trebak M, Moss SE, Bird GS and Mori Y et al.. (2005) The role of canonical transient receptor potential 7 in B-cell receptor-activated channels. J Biol Chem 280: 35346-51 [PMID:16123040]

494. Liman ER. (2007) TRPM5 and taste transduction. Handb Exp Pharmacol: 287-98 [PMID:17217064]

495. Liman ER, Corey DP and Dulac C. (1999) TRP2: a candidate transduction channel for mammalian pheromone sensory signaling. Proc Natl Acad Sci USA 96: 5791-6 [PMID:10318963]

496. Liman, E. R. and Dulac and C.. (2007) TRP Ion Channel Function in Sensory Transduction and Cellular Signaling Cascades Frontiers in Neuroscience Edited by W. B. Liedtke and S. Heller:

497. Lin W, Ezekwe Jr EA, Zhao Z, Liman ER and Restrepo D. (2008) TRPM5-expressing microvillous cells in the main olfactory epithelium. BMC Neurosci 9: 114 [PMID:19025635]

498. Lin W, Margolskee R, Donnert G, Hell SW and Restrepo D. (2007) Olfactory neurons expressing transient receptor potential channel M5 (TRPM5) are involved in sensing semiochemicals. Proc Natl Acad Sci USA 104: 2471-6 [PMID:17267604]

499. Lin W, Ogura T, Margolskee RF, Finger TE and Restrepo D. (2008) TRPM5-expressing solitary chemosensory cells respond to odorous irritants. J Neurophysiol 99: 1451-60 [PMID:18160424]

500. Lin Y and Sun Z. (2012) Antiaging gene Klotho enhances glucose-induced insulin secretion by up-regulating plasma membrane levels of TRPV2 in MIN6 ß-cells. Endocrinology 153: $3029-39$ [PMID:22597535]

501. Lin Z, Chen Q, Lee M, Cao X, Zhang J, Ma D, Chen L, Hu X, Wang H and Wang X et al.. (2012) Exome sequencing reveals mutations in TRPV3 as a cause of Olmsted syndrome. Am J Hum Genet 90: 558-64 [PMID:22405088]

502. Lindvall JM, Blomberg KE, Wennborg A and Smith CI. (2005) Differential expression and molecular characterisation of Lmo7, Myo1e, Sash1, and Mcoln2 genes in Btk-defective B-cells. Cell Immunol 235: 46-55 [PMID:16137664]

503. Link TM, Park U, Vonakis BM, Raben DM, Soloski MJ and Caterina MJ. (2010) TRPV2 has a pivotal role in macrophage particle binding and phagocytosis. Nat Immunol 11: 232-9 [PMID:20118928]

504. Liu B, Escalera J, Balakrishna S, Fan L, Caceres AI, Robinson E, Sui A, McKay MC, McAlexander MA and Herrick CA et al.. (2013) TRPA1 controls inflammation and pruritogen responses in allergic contact dermatitis. FASEB J 27: 3549-63 [PMID:23722916]

505. Liu B, Yao J, Zhu MX and Qin F. (2011) Hysteresis of gating underlines sensitization of TRPV3 channels. J Gen Physiol 138: 509-20 [PMID:22006988]

506. Liu D and Liman ER. (2003) Intracellular Ca2+ and the phospholipid PIP2 regulate the taste transduction ion channel TRPM5. Proc Natl Acad Sci USA 100: 15160-5 [PMID:14657398]

507. Liu D, Zhang Z and Liman ER. (2005) Extracellular acid block and acid-enhanced inactivation of the Ca2+-activated cation channel TRPM5 involve residues in the S3-S4 and S5-S6 extracellular 
domains. J Biol Chem 280: 20691-9 [PMID:15731110]

508. Liu G, Xie C, Sun F, Xu X, Yang Y, Zhang T, Deng Y, Wang D, Huang Z and Yang L et al.. (2010) Clinical significance of transient receptor potential vanilloid 2 expression in human hepatocellular carcinoma. Cancer Genet Cytogenet 197: 54-9 [PMID:20113837]

509. Liu H, Chatel S, Simard C, Syam N, Salle L, Probst V, Morel J, Millat G, Lopez M and Abriel H et al.. (2013) Molecular genetics and functional anomalies in a series of 248 Brugada cases with 11 mutations in the TRPM4 channel. PLoS ONE 8: e54131 [PMID:23382873]

510. Liu K, Samuel M, Ho M, Harrison RK and Paslay JW. (2010) NPPB structure-specifically activates TRPA1 channels. Biochem Pharmacol 80: 113-21 [PMID:20226176]

511. Liu P, Shah BP, Croasdell S and Gilbertson TA. (2011) Transient receptor potential channel type M5 is essential for fat taste. J Neurosci 31: 8634-42 [PMID:21653867]

512. Liu T and Ji RR. (2012) Oxidative stress induces itch via activation of transient receptor potential subtype ankyrin 1 in mice. Neurosci Bull 28: 145-54 [PMID:22466125]

513. Liu W, Su LT, Khadka DK, Mezzacappa C, Komiya Y, Sato A, Habas R and Runnels LW. (2011) TRPM7 regulates gastrulation during vertebrate embryogenesis. Dev Biol 350: 348-57 [PMID:21145885]

514. Liu X, Bandyopadhyay BC, Bandyopadhyay B, Nakamoto T, Singh B, Liedtke W, Melvin JE and Ambudkar I. (2006) A role for AQP5 in activation of TRPV4 by hypotonicity: concerted involvement of AQP5 and TRPV4 in regulation of cell volume recovery. J Biol Chem 281: 1548595 [PMID:16571723]

515. Liu X, Vien T, Duan J, Sheu SH, DeCaen PG and Clapham DE. (2018) Polycystin-2 is an essential ion channel subunit in the primary cilium of the renal collecting duct epithelium. Elife 7 [PMID:29443690]

516. Liu Y and Qin N. (2011) TRPM8 in health and disease: cold sensing and beyond. Adv Exp Med Biol 704: 185-208 [PMID:21290296]

517. Long SB, Campbell EB and Mackinnon R. (2005) Crystal structure of a mammalian voltagedependent Shaker family K+ channel. Science 309: 897-903 [PMID:16002581]

518. Long SB, Tao X, Campbell EB and MacKinnon R. (2007) Atomic structure of a voltage-dependent K+ channel in a lipid membrane-like environment. Nature 450: 376-82 [PMID:18004376]

519. LopezJimenez ND, Cavenagh MM, Sainz E, Cruz-Ithier MA, Battey JF and Sullivan SL. (2006) Two members of the TRPP family of ion channels, Pkd113 and Pkd2l1, are co-expressed in a subset of taste receptor cells. J Neurochem 98: 68-77 [PMID:16805797]

520. Loukin S, Su Z and Kung C. (2011) Increased basal activity is a key determinant in the severity of human skeletal dysplasia caused by TRPV4 mutations. PLoS One 6: e19533 [PMID:21573172]

521. Lowin T, Apitz M, Anders S and Straub RH. (2015) Anti-inflammatory effects of Nacylethanolamines in rheumatoid arthritis synovial cells are mediated by TRPV1 and TRPA1 in a COX-2 dependent manner. Arthritis Res Ther 17: 321 [PMID:26567045]

522. Lucas P, Ukhanov K, Leinders-Zufall T and Zufall F. (2003) A diacylglycerol-gated cation channel in vomeronasal neuron dendrites is impaired in TRPC2 mutant mice: mechanism of pheromone transduction. Neuron 40: 551-61 [PMID:14642279]

523. Luo Y, Vassilev PM, Li X, Kawanabe Y and Zhou J. (2003) Native polycystin 2 functions as a plasma membrane Ca2+-permeable cation channel in renal epithelia. Mol Cell Biol 23: 2600-7 [PMID:12640140]

524. Lussier MP, Cayouette S, Lepage PK, Bernier CL, Francoeur N, St-Hilaire M, Pinard M and Boulay G. (2005) MxA, a member of the dynamin superfamily, interacts with the ankyrin-like repeat domain of TRPC. J Biol Chem 280: 19393-400 [PMID:15757897]

525. Ma S, G G, Ak VE, Jf D and H H. (2008) Menthol derivative WS-12 selectively activates transient receptor potential melastatin-8 (TRPM8) ion channels. Pak J Pharm Sci 21: 370-8 [PMID:18930858]

526. Ma X, Nilius B, Wong JW, Huang Y and Yao X. (2011) Electrophysiological properties of heteromeric TRPV4-C1 channels. Biochim Biophys Acta 1808: 2789-97 [PMID:21871867]

527. Ma X, Qiu S, Luo J, Ma Y, Ngai CY, Shen B, Wong CO, Huang Y and Yao X. (2010) Functional role of vanilloid transient receptor potential 4-canonical transient receptor potential $1 \mathrm{complex}$ in flow-induced Ca2+ influx. Arterioscler Thromb Vasc Biol 30: 851-8 [PMID:20093626]

528. Macpherson LJ, Dubin AE, Evans MJ, Marr F, Schultz PG, Cravatt BF and Patapoutian A. (2007) Noxious compounds activate TRPA1 ion channels through covalent modification of cysteines. Nature 445: 541-5 [PMID:17237762]

529. Macpherson LJ, Geierstanger BH, Viswanath V, Bandell M, Eid SR, Hwang S and Patapoutian A. (2005) The pungency of garlic: activation of TRPA1 and TRPV1 in response to allicin. Curr Biol 15: 929-34 [PMID:15916949]

530. Macpherson LJ, Hwang SW, Miyamoto T, Dubin AE, Patapoutian A and Story GM. (2006) More than cool: promiscuous relationships of menthol and other sensory compounds. Mol Cell Neurosci 32: 335-43 [PMID:16829128]

531. Macpherson LJ, Xiao B, Kwan KY, Petrus MJ, Dubin AE, Hwang S, Cravatt B, Corey DP and Patapoutian A. (2007) An ion channel essential for sensing chemical damage. J Neurosci 27: 
11412-5 [PMID:17942735]

532. Madrid R, Donovan-Rodríguez T, Meseguer V, Acosta MC, Belmonte C and Viana F. (2006) Contribution of TRPM8 channels to cold transduction in primary sensory neurons and peripheral nerve terminals. J Neurosci 26: 12512-25 [PMID:17135413]

533. Magnone M, Bauer I, Poggi A, Mannino E, Sturla L, Brini M, Zocchi E, De Flora A, Nencioni A and Bruzzone S. (2012) NAD+ levels control Ca2+ store replenishment and mitogen-induced increase of cytosolic Ca2+ by Cyclic ADP-ribose-dependent TRPM2 channel gating in human T lymphocytes. J Biol Chem 287: 21067-81 [PMID:22547068]

534. Maher M, Ao H, Banke T, Nasser N, Wu NT, Breitenbucher JG, Chaplan SR and Wickenden AD. (2008) Activation of TRPA1 by farnesyl thiosalicylic acid. Mol Pharmacol 73: 1225-34 [PMID:18171730]

535. Mahieu F, Owsianik G, Verbert L, Janssens A, De Smedt H, Nilius B and Voets T. (2007) TRPM8independent menthol-induced $\mathrm{Ca} 2+$ release from endoplasmic reticulum and Golgi. $J$ Biol Chem 282: 3325-36 [PMID:17142461]

536. Maier T, Follmann M, Hessler G, Kleemann HW, Hachtel S, Fuchs B, Weissmann N, Linz W, Schmidt T and Löhn M et al.. (2015) Discovery and pharmacological characterization of a novel potent inhibitor of diacylglycerol-sensitive TRPC cation channels. Br J Pharmacol 172: 3650-60 [PMID:25847402]

537. Majeed Y, Agarwal AK, Naylor J, Seymour VA, Jiang S, Muraki K, Fishwick CW and Beech DJ. (2010) Cis-isomerism and other chemical requirements of steroidal agonists and partial agonists acting at TRPM3 channels. Br J Pharmacol 161: 430-41 [PMID:20735426]

538. Majeed Y, Amer MS, Agarwal AK, McKeown L, Porter KE, O'Regan DJ, Naylor J, Fishwick CW, Muraki K and Beech DJ. (2011) Stereo-selective inhibition of transient receptor potential TRPC5 cation channels by neuroactive steroids. Br J Pharmacol 162: 1509-20 [PMID:21108630]

539. Majeed Y, Bahnasi Y, Seymour VA, Wilson LA, Milligan CJ, Agarwal AK, Sukumar P, Naylor J and Beech DJ. (2011) Rapid and contrasting effects of rosiglitazone on transient receptor potential TRPM3 and TRPC5 channels. Mol Pharmacol 79: 1023-30 [PMID:21406603]

540. Majhi RK, Sahoo SS, Yadav M, Pratheek BM, Chattopadhyay S and Goswami C. (2015) Functional expression of TRPV channels in T cells and their implications in immune regulation. FEBS J 282: 2661-81 [PMID:25903376]

541. Marigo V, Courville K, Hsu WH, Feng JM and Cheng H. (2009) TRPM4 impacts on Ca2+ signals during agonist-induced insulin secretion in pancreatic beta-cells. Mol Cell Endocrinol 299: 194203 [PMID:19063936]

542. Maroto R, Raso A, Wood TG, Kurosky A, Martinac B and Hamill OP. (2005) TRPC1 forms the stretch-activated cation channel in vertebrate cells. Nat Cell Biol 7: 179-85 [PMID:15665854]

543. Martina JA, Lelouvier B and Puertollano R. (2009) The calcium channel mucolipin-3 is a novel regulator of trafficking along the endosomal pathway. Traffic 10: 1143-56 [PMID:19497048]

544. Masuyama R, Vriens J, Voets T, Karashima Y, Owsianik G, Vennekens R, Lieben L, Torrekens S, Moermans K and Vanden Bosch A et al.. (2008) TRPV4-mediated calcium influx regulates terminal differentiation of osteoclasts. Cell Metab 8: 257-65 [PMID:18762026]

545. Materazzi S, Nassini R, Andrè E, Campi B, Amadesi S, Trevisani M, Bunnett NW, Patacchini R and Geppetti P. (2008) Cox-dependent fatty acid metabolites cause pain through activation of the irritant receptor TRPA1. Proc Natl Acad Sci USA 105: 12045-50 [PMID:18687886]

546. Mathar I, Kecskes M, Van der Mieren G, Jacobs G, Camacho Londoño JE, Uhl S, Flockerzi V, Voets T, Freichel M and Nilius B et al.. (2014) Increased $\beta$-adrenergic inotropy in ventricular myocardium from Trpm4-/- mice. Circ Res 114: 283-94 [PMID:24226423]

547. Mathar I, Vennekens R, Meissner M, Kees F, Van der Mieren G, Camacho Londoño JE, Uhl S, Voets T, Hummel B and van den Bergh A et al.. (2010) Increased catecholamine secretion contributes to hypertension in TRPM4-deficient mice. J Clin Invest 120: 3267-79 [PMID:20679729]

548. Matta JA and Ahern GP. (2007) Voltage is a partial activator of rat thermosensitive TRP channels. J Physiol (Lond.) 585: 469-82 [PMID:17932142]

549. Matta JA, Cornett PM, Miyares RL, Abe K, Sahibzada N and Ahern GP. (2008) General anesthetics activate a nociceptive ion channel to enhance pain and inflammation. Proc Natl Acad Sci USA 105: 8784-9 [PMID:18574153]

550. McCleverty CJ, Koesema E, Patapoutian A, Lesley SA and Kreusch A. (2006) Crystal structure of the human TRPV2 channel ankyrin repeat domain. Protein Sci 15: 2201-6 [PMID:16882997]

551. McHugh D, Flemming R, Xu SZ, Perraud AL and Beech DJ. (2003) Critical intracellular Ca2+ dependence of transient receptor potential melastatin 2 (TRPM2) cation channel activation. $J$ Biol Chem 278: 11002-6 [PMID:12529379]

552. McIntyre P, McLatchie LM, Chambers A, Phillips E, Clarke M, Savidge J, Toms C, Peacock M, Shah K and Winter J et al.. (2001) Pharmacological differences between the human and rat vanilloid receptor 1 (VR1). Br J Pharmacol 132: 1084-94 [PMID:11226139]

553. McKay RR, Szymeczek-Seay CL, Lievremont JP, Bird GS, Zitt C, Jüngling E, Lückhoff A and Putney Jr JW. (2000) Cloning and expression of the human transient receptor potential 4 (TRP4) 
gene: localization and functional expression of human TRP4 and TRP3. Biochem J 351 Pt 3 : 735-46 [PMID:11042129]

554. McKemy DD, Neuhausser WM and Julius D. (2002) Identification of a cold receptor reveals a general role for TRP channels in thermosensation. Nature 416: 52-8 [PMID:11882888]

555. McNamara CR, Mandel-Brehm J, Bautista DM, Siemens J, Deranian KL, Zhao M, Hayward NJ, Chong JA, Julius D and Moran MM et al.. (2007) TRPA1 mediates formalin-induced pain. Proc Natl Acad Sci USA 104: 13525-30 [PMID:17686976]

556. McNamara FN, Randall A and Gunthorpe MJ. (2005) Effects of piperine, the pungent component of black pepper, at the human vanilloid receptor (TRPV1). Br J Pharmacol 144: 781-90 [PMID:15685214]

557. McNulty S and Fonfria E. (2005) The role of TRPM channels in cell death. Pflugers Arch 451: 235-42 [PMID:16025303]

558. Mei ZZ, Mao HJ and Jiang LH. (2006) Conserved cysteine residues in the pore region are obligatory for human TRPM2 channel function. Am J Physiol, Cell Physiol 291: C1022-8 [PMID:16822940]

559. Melzer N, Hicking G, Göbel K and Wiendl H. (2012) TRPM2 cation channels modulate T cell effector functions and contribute to autoimmune CNS inflammation. PLoS ONE 7: e47617 [PMID:23077651]

560. Mercado J, Gordon-Shaag A, Zagotta WN and Gordon SE. (2010) Ca2+-dependent desensitization of TRPV2 channels is mediated by hydrolysis of phosphatidylinositol 4,5bisphosphate. J Neurosci 30: 13338-47 [PMID:20926660]

561. Meseguer V, Alpizar YA, Luis E, Tajada S, Denlinger B, Fajardo O, Manenschijn JA, FernándezPeña C, Talavera A and Kichko T et al.. (2014) TRPA1 channels mediate acute neurogenic inflammation and pain produced by bacterial endotoxins. Nat Commun 5: 3125 [PMID:24445575]

562. Meseguer V, Karashima Y, Talavera K, D'Hoedt D, Donovan-Rodríguez T, Viana F, Nilius B and Voets T. (2008) Transient receptor potential channels in sensory neurons are targets of the antimycotic agent clotrimazole. J Neurosci 28: 576-86 [PMID:18199759]

563. Miao Y, Li G, Zhang X, Xu H and Abraham SN. (2015) A TRP Channel Senses Lysosome Neutralization by Pathogens to Trigger Their Expulsion. Cell 161: 1306-19 [PMID:26027738]

564. Miehe S, Bieberstein A, Arnould I, Ihdene O, Rütten H and Strübing C. (2010) The phospholipidbinding protein SESTD1 is a novel regulator of the transient receptor potential channels TRPC4 and TRPC5. J Biol Chem 285: 12426-34 [PMID:20164195]

565. Miehe S, Crause P, Schmidt T, Löhn M, Kleemann HW, Licher T, Dittrich W, Rütten H and Strübing C. (2012) Inhibition of diacylglycerol-sensitive TRPC channels by synthetic and natural steroids. PLoS ONE 7: e35393 [PMID:22530015]

566. Mihara H, Boudaka A, Shibasaki K, Yamanaka A, Sugiyama T and Tominaga M. (2010) Involvement of TRPV2 activation in intestinal movement through nitric oxide production in mice. J Neurosci 30: 16536-44 [PMID:21147993]

567. Mihara H, Suzuki N, Yamawaki H, Tominaga M and Sugiyama T. (2013) TRPV2 ion channels expressed in inhibitory motor neurons of gastric myenteric plexus contribute to gastric adaptive relaxation and gastric emptying in mice. Am J Physiol Gastrointest Liver Physiol 304: G235-40 [PMID:23203157]

568. Miller AJ, Du J, Rowan S, Hershey CL, Widlund HR and Fisher DE. (2004) Transcriptional regulation of the melanoma prognostic marker melastatin (TRPM1) by MITF in melanocytes and melanoma. Cancer Res 64: 509-16 [PMID:14744763]

569. Miller M, Shi J, Zhu Y, Kustov M, Tian JB, Stevens A, Wu M, Xu J, Long S and Yang P et al.. (2011) Identification of ML204, a novel potent antagonist that selectively modulates native TRPC4/C5 ion channels. J Biol Chem 286: 33436-46 [PMID:21795696]

570. Minard A, Bauer CC, Chuntharpursat-Bon E, Pickles IB, Wright DJ, Ludlow MJ, Burnham MP, Warriner SL, Beech DJ and Muraki K et al.. (2019) Potent, selective, and subunit-dependent activation of TRPC5 channels by a xanthine derivative. Br J Pharmacol 176: 3924-3938 [PMID:31277085]

571. Minard A, Bauer CC, Wright DJ, Rubaiy HN, Muraki K, Beech DJ and Bon RS. (2018) Remarkable Progress with Small-Molecule Modulation of TRPC1/4/5 Channels: Implications for Understanding the Channels in Health and Disease. Cells 7 [PMID:29865154]

572. Mishra SK, Tisel SM, Orestes P, Bhangoo SK and Hoon MA. (2011) TRPV1-lineage neurons are required for thermal sensation. EMBO J 30: 582-93 [PMID:21139565]

573. Mitrovic S, Nogueira C, Cantero-Recasens G, Kiefer K, Fernández-Fernández JM, Popoff JF, Casano L, Bard FA, Gomez R and Valverde MA et al.. (2013) TRPM5-mediated calcium uptake regulates mucin secretion from human colon goblet cells. Elife 2: e00658 [PMID:23741618]

574. Mittermeier L, Demirkhanyan L, Stadlbauer B, Breit A, Recordati C, Hilgendorff A, Matsushita M, Braun A, Simmons DG and Zakharian E et al.. (2019) TRPM7 is the central gatekeeper of intestinal mineral absorption essential for postnatal survival. Proc Natl Acad Sci USA 116: 47064715 [PMID:30770447] 
575. Miura S, Takahashi K, Imagawa T, Uchida K, Saito S, Tominaga M and Ohta T. (2013) Involvement of TRPA1 activation in acute pain induced by cadmium in mice. Mol Pain 9: 7 [PMID:23448290]

576. Miyagi K, Kiyonaka S, Yamada K, Miki T, Mori E, Kato K, Numata T, Sawaguchi Y, Numaga T and Kimura T et al.. (2009) A pathogenic C terminus-truncated polycystin-2 mutant enhances receptor-activated Ca2+ entry via association with TRPC3 and TRPC7. J Biol Chem 284: 3440012 [PMID:19812035]

577. Mizoguchi F, Mizuno A, Hayata T, Nakashima K, Heller S, Ushida T, Sokabe M, Miyasaka N, Suzuki M and Ezura Y et al.. (2008) Transient receptor potential vanilloid 4 deficiency suppresses unloading-induced bone loss. J Cell Physiol 216: 47-53 [PMID:18264976]

578. Mizuno N, Kitayama S, Saishin Y, Shimada S, Morita K, Mitsuhata C, Kurihara H and Dohi T. (1999) Molecular cloning and characterization of rat trp homologues from brain. Brain Res Mol Brain Res 64: 41-51 [PMID:9889314]

579. Mochizuki T, Wu G, Hayashi T, Xenophontos SL, Veldhuisen B, Saris JJ, Reynolds DM, Cai Y, Gabow PA and Pierides A et al.. (1996) PKD2, a gene for polycystic kidney disease that encodes an integral membrane protein. Science 272: 1339-42 [PMID:8650545]

580. Monet M, Gkika D, Lehen'kyi V, Pourtier A, Vanden Abeele F, Bidaux G, Juvin V, Rassendren F, Humez S and Prevarsakaya N. (2009) Lysophospholipids stimulate prostate cancer cell migration via TRPV2 channel activation. Biochim Biophys Acta 1793: 528-39 [PMID:19321128]

581. Monet M, Lehen'kyi V, Gackiere F, Firlej V, Vandenberghe M, Roudbaraki M, Gkika D, Pourtier A, Bidaux G and Slomianny C et al.. (2010) Role of cationic channel TRPV2 in promoting prostate cancer migration and progression to androgen resistance. Cancer Res 70: 1225-35 [PMID:20103638]

582. Monteilh-Zoller MK, Hermosura MC, Nadler MJ, Scharenberg AM, Penner R and Fleig A. (2003) TRPM7 provides an ion channel mechanism for cellular entry of trace metal ions. J Gen Physiol 121: 49-60 [PMID:12508053]

583. Montell C and Rubin GM. (1989) Molecular characterization of the Drosophila trp locus: a putative integral membrane protein required for phototransduction. Neuron 2: 1313-23 [PMID:2516726]

584. Moqrich A, Hwang SW, Earley TJ, Petrus MJ, Murray AN, Spencer KS, Andahazy M, Story GM and Patapoutian A. (2005) Impaired thermosensation in mice lacking TRPV3, a heat and camphor sensor in the skin. Science 307: 1468-72 [PMID:15746429]

585. Moran MM and Szallasi A. (2018) Targeting nociceptive transient receptor potential channels to treat chronic pain: current state of the field. Br J Pharmacol 175: 2185-2203 [PMID:28924972]

586. Morelli MB, Nabissi M, Amantini C, Farfariello V, Ricci-Vitiani L, di Martino S, Pallini R, Larocca LM, Caprodossi S and Santoni M et al.. (2012) The transient receptor potential vanilloid-2 cation channel impairs glioblastoma stem-like cell proliferation and promotes differentiation. Int J Cancer 131: E1067-77 [PMID:22492283]

587. Morgans CW, Zhang J, Jeffrey BG, Nelson SM, Burke NS, Duvoisin RM and Brown RL. (2009) TRPM1 is required for the depolarizing light response in retinal ON-bipolar cells. Proc Natl Acad Sci USA 106: 19174-8 [PMID:19861548]

588. Mori Y, Takada N, Okada T, Wakamori M, Imoto K, Wanifuchi H, Oka H, Oba A, Ikenaka K and Kurosaki T. (1998) Differential distribution of TRP Ca2+ channel isoforms in mouse brain. Neuroreport 9: 507-15 [PMID:9512398]

589. Motter AL and Ahern GP. (2012) TRPA1 is a polyunsaturated fatty acid sensor in mammals. PLoS ONE 7: e38439 [PMID:22723860]

590. Moussaieff A, Rimmerman N, Bregman T, Straiker A, Felder CC, Shoham S, Kashman Y, Huang $\mathrm{SM}$, Lee $\mathrm{H}$ and Shohami $\mathrm{E}$ et al.. (2008) Incensole acetate, an incense component, elicits psychoactivity by activating TRPV3 channels in the brain. FASEB J 22: 3024-34 [PMID:18492727]

591. MRC. AZD1386 TRPV1 ion channel inhibitor.

592. Mukhopadhyay I, Gomes P, Aranake S, Shetty M, Karnik P, Damle M, Kuruganti S, Thorat S and Khairatkar-Joshi N. (2011) Expression of functional TRPA1 receptor on human lung fibroblast and epithelial cells. J Recept Signal Transduct Res 31: 350-8 [PMID:21848366]

593. Murakami M, Ohba T, Xu F, Shida S, Satoh E, Ono K, Miyoshi I, Watanabe H, Ito H and Iijima T. (2005) Genomic organization and functional analysis of murine PKD2L1. J Biol Chem 280: 562635 [PMID:15548533]

594. Murakami M, Xu F, Miyoshi I, Sato E, Ono K and Iijima T. (2003) Identification and characterization of the murine TRPM4 channel. Biochem Biophys Res Commun 307: 522-8 [PMID:12893253]

595. Muraki K, Iwata Y, Katanosaka Y, Ito T, Ohya S, Shigekawa M and Imaizumi Y. (2003) TRPV2 is a component of osmotically sensitive cation channels in murine aortic myocytes. Circ Res 93: 829-38 [PMID:14512441]

596. Murata T, Lin MI, Stan RV, Bauer PM, Yu J and Sessa WC. (2007) Genetic evidence supporting caveolae microdomain regulation of calcium entry in endothelial cells. J Biol Chem 282: 16631- 
43 [PMID:17416589]

597. Myers BR, Sigal YM and Julius D. (2009) Evolution of thermal response properties in a coldactivated TRP channel. PLoS ONE 4: e5741 [PMID:19492038]

598. Mälkiä A, Madrid R, Meseguer V, de la Peña E, Valero M, Belmonte C and Viana F. (2007) Bidirectional shifts of TRPM8 channel gating by temperature and chemical agents modulate the cold sensitivity of mammalian thermoreceptors. J Physiol (Lond.) 581: 155-74 [PMID:17317754]

599. Mälkiä A, Morenilla-Palao C and Viana F. (2011) The emerging pharmacology of TRPM8 channels: hidden therapeutic potential underneath a cold surface. Curr Pharm Biotechnol 12: 54-67 [PMID:20932258]

600. Müller D, Hoenderop JG, Meij IC, van den Heuvel LP, Knoers NV, den Hollander AI, Eggert P, García-Nieto V, Claverie-Martín F and Bindels RJ. (2000) Molecular cloning, tissue distribution, and chromosomal mapping of the human epithelial Ca2+ channel (ECAC1). Genomics 67: 48-53 [PMID:10945469]

601. Na T and Peng JB. (2014) TRPV5: a $\mathrm{Ca}(2+)$ channel for the fine-tuning of $\mathrm{Ca}(2+)$ reabsorption. Handb Exp Pharmacol 222: 321-57 [PMID:24756712]

602. Nabissi M, Morelli MB, Amantini C, Farfariello V, Ricci-Vitiani L, Caprodossi S, Arcella A, Santoni M, Giangaspero F and De Maria R et al.. (2010) TRPV2 channel negatively controls glioma cell proliferation and resistance to Fas-induced apoptosis in ERK-dependent manner. Carcinogenesis 31: 794-803 [PMID:20093382]

603. Nabissi M, Morelli MB, Santoni M and Santoni G. (2013) Triggering of the TRPV2 channel by cannabidiol sensitizes glioblastoma cells to cytotoxic chemotherapeutic agents. Carcinogenesis 34: 48-57 [PMID:23079154]

604. Nadler MJ, Hermosura MC, Inabe K, Perraud AL, Zhu Q, Stokes AJ, Kurosaki T, Kinet JP, Penner $\mathrm{R}$ and Scharenberg AM et al.. (2001) LTRPC7 is a Mg.ATP-regulated divalent cation channel required for cell viability. Nature 411: 590-5 [PMID:11385574]

605. Nagamine K, Kudoh J, Minoshima S, Kawasaki K, Asakawa S, Ito F and Shimizu N. (1998) Molecular cloning of a novel putative Ca2+ channel protein (TRPC7) highly expressed in brain. Genomics 54: 124-31 [PMID:9806837]

606. Nagasawa M and Kojima I. (2012) Translocation of calcium-permeable TRPV2 channel to the podosome: Its role in the regulation of podosome assembly. Cell Calcium 51: 186-93 [PMID:22226146]

607. Nagasawa M, Nakagawa Y, Tanaka S and Kojima I. (2007) Chemotactic peptide fMetLeuPhe induces translocation of the TRPV2 channel in macrophages. J Cell Physiol 210: 692-702 [PMID:17154364]

608. Nagase T, Kikuno R, Nakayama M, Hirosawa M and Ohara O. (2000) Prediction of the coding sequences of unidentified human genes. XVIII. The complete sequences of 100 new cDNA clones from brain which code for large proteins in vitro. DNA Res 7: 273-81 [PMID:10997877]

609. Nagata K, Duggan A, Kumar G and García-Añoveros J. (2005) Nociceptor and hair cell transducer properties of TRPA1, a channel for pain and hearing. J Neurosci 25: 4052-61 [PMID:15843607]

610. Nagata K, Zheng L, Madathany T, Castiglioni AJ, Bartles JR and García-Añoveros J. (2008) The varitint-waddler (Va) deafness mutation in TRPML3 generates constitutive, inward rectifying currents and causes cell degeneration. Proc Natl Acad Sci USA 105: 353-8 [PMID:18162548]

611. Nakamura M, Sanuki R, Yasuma TR, Onishi A, Nishiguchi KM, Koike C, Kadowaki M, Kondo M, Miyake Y and Furukawa T. (2010) TRPM1 mutations are associated with the complete form of congenital stationary night blindness. Mol Vis 16: 425-37 [PMID:20300565]

612. Nakanishi O, Fujimori Y, Aizawa N, Hayashi T, Matsuzawa A, Kobayashi JI, Hirasawa H, Mutai Y, Tanada F and Igawa Y. (2020) KPR-5714, a Novel Transient Receptor Potential Melastatin 8 Antagonist, Improves Overactive Bladder via Inhibition of Bladder Afferent Hyperactivity in Rats. J Pharmacol Exp Ther 373: 239-247 [PMID:32102918]

613. Nakashimo Y, Takumida M, Fukuiri T, Anniko M and Hirakawa K. (2010) Expression of transient receptor potential channel vanilloid (TRPV) $1 \& \# x 2013 ; 4$, melastin (TRPM) 5 and 8, and ankyrin (TRPA1) in the normal and methimazole-treated mouse olfactory epithelium. Acta Otolaryngol 130: 1278-86 [PMID:20586674]

614. Narukawa M, Koizumi K, Iwasaki Y, Kubota K and Watanabe T. (2010) Galangal pungent component, 1'-acetoxychavicol acetate, activates TRPA1. Biosci Biotechnol Biochem 74: 1694-6 [PMID:20699565]

615. Nassenstein C, Kwong K, Taylor-Clark T, Kollarik M, Macglashan DM, Braun A and Undem BJ. (2008) Expression and function of the ion channel TRPA1 in vagal afferent nerves innervating mouse lungs. J Physiol (Lond.) 586: 1595-604 [PMID:18218683]

616. Nassini R, Gees M, Harrison S, De Siena G, Materazzi S, Moretto N, Failli P, Preti D, Marchetti $\mathrm{N}$ and Cavazzini A et al.. (2011) Oxaliplatin elicits mechanical and cold allodynia in rodents via TRPA1 receptor stimulation. Pain 152: 1621-31 [PMID:21481532]

617. Nassini R, Materazzi S, Andrè E, Sartiani L, Aldini G, Trevisani M, Carnini C, Massi D, Pedretti P and Carini M et al.. (2010) Acetaminophen, via its reactive metabolite N-acetyl-p-benzo- 
quinoneimine and transient receptor potential ankyrin-1 stimulation, causes neurogenic inflammation in the airways and other tissues in rodents. FASEB J 24: 4904-16

[PMID:20720158]

618. Nassini R, Materazzi S, Vriens J, Prenen J, Benemei S, De Siena G, la Marca G, Andrè E, Preti D and Avonto C et al.. (2012) The 'headache tree' via umbellulone and TRPA1 activates the trigeminovascular system. Brain 135: 376-90 [PMID:22036959]

619. Nassini R, Pedretti P, Moretto N, Fusi C, Carnini C, Facchinetti F, Viscomi AR, Pisano AR, Stokesberry S and Brunmark C et al.. (2012) Transient receptor potential ankyrin 1 channel localized to non-neuronal airway cells promotes non-neurogenic inflammation. PLoS ONE 7: e42454 [PMID:22905134]

620. Nativi C, Gualdani R, Dragoni E, Di Cesare Mannelli L, Sostegni S, Norcini M, Gabrielli G, la Marca G, Richichi B and Francesconi O et al.. (2013) A TRPA1 antagonist reverts oxaliplatininduced neuropathic pain. Sci Rep 3: 2005 [PMID:23774285]

621. Naylor J, Minard A, Gaunt HJ, Amer MS, Wilson LA, Migliore M, Cheung SY, Rubaiy HN, Blythe NM and Musialowski KE et al.. (2016) Natural and synthetic flavonoid modulation of TRPC5 channels. Br J Pharmacol 173: 562-74 [PMID:26565375]

622. Naziroğlu M and Ozgül C. (2012) Effects of antagonists and heat on TRPM8 channel currents in dorsal root ganglion neuron activated by nociceptive cold stress and menthol. Neurochem Res 37: 314-20 [PMID:21964764]

623. Nealen ML, Gold MS, Thut PD and Caterina MJ. (2003) TRPM8 mRNA is expressed in a subset of cold-responsive trigeminal neurons from rat. J Neurophysiol 90: 515-20 [PMID:12634279]

624. Nedungadi TP, Dutta M, Bathina CS, Caterina MJ and Cunningham JT. (2012) Expression and distribution of TRPV2 in rat brain. Exp Neurol 237: 223-37 [PMID:22750329]

625. Neely GG, Keene AC, Duchek P, Chang EC, Wang QP, Aksoy YA, Rosenzweig M, Costigan M, Woolf CJ and Garrity PA et al.. (2011) TrpA1 regulates thermal nociception in Drosophila. PLoS ONE 6: e24343 [PMID:21909389]

626. Neeper MP, Liu Y, Hutchinson TL, Wang Y, Flores CM and Qin N. (2007) Activation properties of heterologously expressed mammalian TRPV2: evidence for species dependence. J Biol Chem 282: 15894-902 [PMID:17395593]

627. Nelson PL, Zolochevska O, Figueiredo ML, Soliman A, Hsu WH, Feng JM, Zhang H and Cheng H. (2011) Regulation of $\mathrm{Ca}(2+)$-entry in pancreatic $\alpha$-cell line by transient receptor potential melastatin 4 plays a vital role in glucagon release. Mol Cell Endocrinol 335: 126-34 [PMID:21238535]

628. Nie L, Kanzaki M, Shibata H and Kojima I. (1998) Activation of calcium-permeable cation channel by insulin in Chinese hamster ovary cells expressing human insulin receptors. Endocrinology 139: 179-88 [PMID:9421413]

629. Nie L, Oishi Y, Doi I, Shibata H and Kojima I. (1997) Inhibition of proliferation of MCF-7 breast cancer cells by a blocker of $\mathrm{Ca}(2+)$-permeable channel. Cell Calcium 22: 75-82 [PMID:9292225]

630. Nie M, Bal MS, Liu J, Yang Z, Rivera C, Wu XR, Hoenderop JGJ, Bindels RJM, Marciano DK and Wolf MTF. (2018) Uromodulin regulates renal magnesium homeostasis through the ion channel transient receptor potential melastatin 6 (TRPM6). J Biol Chem 293: 16488-16502 [PMID:30139743]

631. Niemeyer BA, Bergs C, Wissenbach U, Flockerzi V and Trost C. (2001) Competitive regulation of CaT-like-mediated Ca2+ entry by protein kinase C and calmodulin. Proc Natl Acad Sci USA 98: 3600-5 [PMID:11248124]

632. Niforatos W, Zhang XF, Lake MR, Walter KA, Neelands T, Holzman TF, Scott VE, Faltynek CR, Moreland RB and Chen J. (2007) Activation of TRPA1 channels by the fatty acid amide hydrolase inhibitor 3'-carbamoylbiphenyl-3-yl cyclohexylcarbamate (URB597). Mol Pharmacol 71: 1209-16 [PMID:17314320]

633. Nijenhuis T, Hoenderop JG, van der Kemp AW and Bindels RJ. (2003) Localization and regulation of the epithelial Ca2+ channel TRPV6 in the kidney. J Am Soc Nephrol 14: 2731-40 [PMID:14569082]

634. Nilius B. (2007) TRP channels in disease. Biochim Biophys Acta 1772: 805-12 [PMID:17368864]

635. Nilius B and Flockerzi V. (2014) Mammalian transient receptor potential (TRP) cation channels. Preface. Handb Exp Pharmacol 223: v - vi [PMID:25296415]

636. Nilius B, Mahieu F, Prenen J, Janssens A, Owsianik G, Vennekens R and Voets T. (2006) The Ca2+-activated cation channel TRPM4 is regulated by phosphatidylinositol 4,5-biphosphate. EMBO J 25: 467-78 [PMID:16424899]

637. Nilius B and Owsianik G. (2010) Transient receptor potential channelopathies. Pflugers Arch 460: 437-50 [PMID:20127491]

638. Nilius B, Owsianik G and Voets T. (2008) Transient receptor potential channels meet phosphoinositides. EMBO J 27: 2809-16 [PMID:18923420]

639. Nilius B, Owsianik G, Voets T and Peters JA. (2007) Transient receptor potential cation channels in disease. Physiol Rev 87: 165-217 [PMID:17237345]

640. Nilius B, Prenen J, Droogmans G, Voets T, Vennekens R, Freichel M, Wissenbach U and 
Flockerzi V. (2003) Voltage dependence of the Ca2+-activated cation channel TRPM4. J Biol Chem 278: 30813-20 [PMID:12799367]

641. Nilius B, Prenen J, Hoenderop JG, Vennekens R, Hoefs S, Weidema AF, Droogmans G and Bindels RJ. (2002) Fast and slow inactivation kinetics of the Ca2+ channels ECaC1 and ECaC2 (TRPV5 and TRPV6). Role of the intracellular loop located between transmembrane segments 2 and 3. J Biol Chem 277: 30852-8 [PMID:12077127]

642. Nilius B, Prenen J, Janssens A, Owsianik G, Wang C, Zhu MX and Voets T. (2005) The selectivity filter of the cation channel TRPM4. J Biol Chem 280: 22899-906 [PMID:15845551]

643. Nilius B, Prenen J, Janssens A, Voets T and Droogmans G. (2004) Decavanadate modulates gating of TRPM4 cation channels. J Physiol (Lond.) 560: 753-65 [PMID:15331675]

644. Nilius B, Prenen J, Tang J, Wang C, Owsianik G, Janssens A, Voets T and Zhu MX. (2005) Regulation of the $\mathrm{Ca} 2+$ sensitivity of the nonselective cation channel TRPM4. J Biol Chem 280: 6423-33 [PMID:15590641]

645. Nilius B, Prenen J, Vennekens R, Hoenderop JG, Bindels RJ and Droogmans G. (2001) Pharmacological modulation of monovalent cation currents through the epithelial $\mathrm{Ca} 2+$ channel ECaC1. Br J Pharmacol 134: 453-62 [PMID:11588099]

646. Nilius B, Prenen J, Voets T and Droogmans G. (2004) Intracellular nucleotides and polyamines inhibit the Ca2+-activated cation channel TRPM4b. Pflugers Arch 448: 70-5 [PMID:14758478]

647. Nilius B, Talavera K, Owsianik G, Prenen J, Droogmans G and Voets T. (2005) Gating of TRP channels: a voltage connection? J Physiol (Lond.) 567: 35-44 [PMID:15878939]

648. Nilius B and Vennekens R. (2006) From cardiac cation channels to the molecular dissection of the transient receptor potential channel TRPM4. Pflugers Arch 453: 313-21 [PMID:16680483]

649. Nilius B, Vennekens R, Prenen J, Hoenderop JG, Bindels RJ and Droogmans G. (2000) Whole-cell and single channel monovalent cation currents through the novel rabbit epithelial Ca2+ channel ECaC. J Physiol (Lond.) 527 Pt 2: 239-48 [PMID:10970426]

650. Nilius B and Voets T. (2013) The puzzle of TRPV4 channelopathies. EMBO Rep 14: 152-63 [PMID:23306656]

651. Nilius B, Vriens J, Prenen J, Droogmans G and Voets T. (2004) TRPV4 calcium entry channel: a paradigm for gating diversity. Am J Physiol, Cell Physiol 286: C195-205 [PMID:14707014]

652. Nina DUllrich. (2005) PhD Thesis. In TRPM4 and TRPM5: Functional characterisation and comparison of two novel $\mathrm{Ca}^{2+}$-activated cation channels of the TRPM subfamily Faculteit Geneeskunde, Dept. Moleculaire Celbiologie, KU Leuven:

653. Nishimura G, Lausch E, Savarirayan R, Shiba M, Spranger J, Zabel B, Ikegawa S, Superti-Furga A and Unger S. (2012) TRPV4-associated skeletal dysplasias. Am J Med Genet C Semin Med Genet 160C: 190-204 [PMID:22791502]

654. Nomura H, Turco AE, Pei Y, Kalaydjieva L, Schiavello T, Weremowicz S, Ji W, Morton CC, Meisler M and Reeders ST et al.. (1998) Identification of PKDL, a novel polycystic kidney disease 2-like gene whose murine homologue is deleted in mice with kidney and retinal defects. J Biol Chem 273: 25967-73 [PMID:9748274]

655. Nozawa K, Kawabata-Shoda E, Doihara H, Kojima R, Okada H, Mochizuki S, Sano Y, Inamura K, Matsushime $\mathrm{H}$ and Koizumi T et al.. (2009) TRPA1 regulates gastrointestinal motility through serotonin release from enterochromaffin cells. Proc Natl Acad Sci USA 106: 3408-13 [PMID:19211797]

656. Numazaki M, Tominaga T, Takeuchi K, Murayama N, Toyooka H and Tominaga M. (2003) Structural determinant of TRPV1 desensitization interacts with calmodulin. Proc Natl Acad Sci USA 100: 8002-6 [PMID:12808128]

657. Oancea E, Vriens J, Brauchi S, Jun J, Splawski I and Clapham DE. (2009) TRPM1 forms ion channels associated with melanin content in melanocytes. Sci Signal 2: ra21 [PMID:19436059]

658. Oancea E, Wolfe JT and Clapham DE. (2006) Functional TRPM7 channels accumulate at the plasma membrane in response to fluid flow. Circ Res 98: 245-53 [PMID:16357306]

659. Obata K, Katsura H, Mizushima T, Yamanaka H, Kobayashi K, Dai Y, Fukuoka T, Tokunaga A, Tominaga M and Noguchi K. (2005) TRPA1 induced in sensory neurons contributes to cold hyperalgesia after inflammation and nerve injury. J Clin Invest 115: 2393-401 [PMID:16110328]

660. Obermüller N, Gallagher AR, Cai Y, Gassler N, Gretz N, Somlo S and Witzgall R. (1999) The rat pkd2 protein assumes distinct subcellular distributions in different organs. Am J Physiol 277: F914-25 [PMID:10600939]

661. Oberwinkler J, Lis A, Giehl KM, Flockerzi V and Philipp SE. (2005) Alternative splicing switches the divalent cation selectivity of TRPM3 channels. J Biol Chem 280: 22540-8 [PMID:15824111]

662. Oberwinkler J and Philipp SE. (2014) TRPM3. Handb Exp Pharmacol 222: 427-59 [PMID:24756716]

663. Oberwinkler J and Phillipp SE. (2007) TRPM3. Handb Exp Pharmacol: 253-67 [PMID:17217062]

664. Obukhov AG and Nowycky MC. (2008) TRPC5 channels undergo changes in gating properties during the activation-deactivation cycle. J Cell Physiol 216: 162-71 [PMID:18247362]

665. Obukhov AG and Nowycky MC. (2005) A cytosolic residue mediates Mg2+ block and regulates inward current amplitude of a transient receptor potential channel. J Neurosci 25: 1234-9 
[PMID:15689561]

666. Odell AF, Van Helden DF and Scott JL. (2008) The spectrin cytoskeleton influences the surface expression and activation of human transient receptor potential channel 4 channels. J Biol Chem 283: 4395-407 [PMID:18048348]

667. Ohki G, Miyoshi T, Murata M, Ishibashi K, Imai M and Suzuki M. (2000) A calcium-activated cation current by an alternatively spliced form of Trp3 in the heart. J Biol Chem 275: 39055-60 [PMID:10984475]

668. Oike H, Wakamori M, Mori Y, Nakanishi H, Taguchi R, Misaka T, Matsumoto I and Abe K. (2006) Arachidonic acid can function as a signaling modulator by activating the TRPM5 cation channel in taste receptor cells. Biochim Biophys Acta 1761: 1078-84 [PMID:16935556]

669. Okada T, Inoue R, Yamazaki K, Maeda A, Kurosaki T, Yamakuni T, Tanaka I, Shimizu S, Ikenaka $\mathrm{K}$ and Imoto $\mathrm{K}$ et al.. (1999) Molecular and functional characterization of a novel mouse transient receptor potential protein homologue TRP7. $\mathrm{Ca}(2+)$-permeable cation channel that is constitutively activated and enhanced by stimulation of G protein-coupled receptor. J Biol Chem 274: 27359-70 [PMID:10488066]

670. Okada T, Shimizu S, Wakamori M, Maeda A, Kurosaki T, Takada N, Imoto K and Mori Y. (1998) Molecular cloning and functional characterization of a novel receptor-activated TRP Ca2+ channel from mouse brain. J Biol Chem 273: 10279-87 [PMID:9553080]

671. Olah ME, Jackson MF, Li H, Perez Y, Sun HS, Kiyonaka S, Mori Y, Tymianski M and MacDonald JF. (2009) Ca2+-dependent induction of TRPM2 currents in hippocampal neurons. J Physiol (Lond.) 587: 965-79 [PMID:19124544]

672. Omura M and Mombaerts P. (2014) Trpc2-expressing sensory neurons in the main olfactory epithelium of the mouse. Cell Rep 8: 583-95 [PMID:25001287]

673. Omura M and Mombaerts P. (2015) Trpc2-expressing sensory neurons in the mouse main olfactory epithelium of type B express the soluble guanylate cyclase Gucy1b2. Mol Cell Neurosci 65: 114-24 [PMID:25701815]

674. Ong AC and Harris PC. (2015) A polycystin-centric view of cyst formation and disease: the polycystins revisited. Kidney Int 88: 699-710 [PMID:26200945]

675. Ong HL and Ambudkar IS. (2017) STIM-TRP Pathways and Microdomain Organization: Contribution of TRPC1 in Store-Operated $\mathrm{Ca}^{2+}$ Entry: Impact on $\mathrm{Ca}^{2+}$ Signaling and Cell Function. Adv Exp Med Biol 993: 159-188 [PMID:28900914]

676. Onohara N, Nishida M, Inoue R, Kobayashi H, Sumimoto H, Sato Y, Mori Y, Nagao T and Kurose H. (2006) TRPC3 and TRPC6 are essential for angiotensin II-induced cardiac hypertrophy. EMBO J 25: 5305-16 [PMID:17082763]

677. Ordaz B, Tang J, Xiao R, Salgado A, Sampieri A, Zhu MX and Vaca L. (2005) Calmodulin and calcium interplay in the modulation of TRPC5 channel activity. Identification of a novel Cterminal domain for calcium/calmodulin-mediated facilitation. J Biol Chem 280: 30788-96 [PMID:15987684]

678. Otsuguro K, Tang J, Tang Y, Xiao R, Freichel M, Tsvilovskyy V, Ito S, Flockerzi V, Zhu MX and Zholos AV. (2008) Isoform-specific inhibition of TRPC4 channel by phosphatidylinositol 4,5bisphosphate. J Biol Chem 283: 10026-36 [PMID:18230622]

679. Owsianik G, Talavera K, Voets T and Nilius B. (2006) Permeation and selectivity of TRP channels. Annu Rev Physiol 68: 685-717 [PMID:16460288]

680. Ozhathil LC, Delalande C, Bianchi B, Nemeth G, Kappel S, Thomet U, Ross-Kaschitza D, Simonin C, Rubin M and Gertsch J et al.. (2018) Identification of potent and selective small molecule inhibitors of the cation channel TRPM4. Br J Pharmacol 175: 2504-2519 [PMID:29579323]

681. Parenti A, De Logu F, Geppetti P and Benemei S. (2016) What is the evidence for the role of TRP channels in inflammatory and immune cells? Br J Pharmacol 173: 953-69 [PMID:26603538]

682. Park CK, Xu ZZ, Liu T, Lü N, Serhan CN and Ji RR. (2011) Resolvin D2 is a potent endogenous inhibitor for transient receptor potential subtype V1/A1, inflammatory pain, and spinal cord synaptic plasticity in mice: distinct roles of resolvin D1, D2, and E1. J Neurosci 31: 18433-8 [PMID:22171045]

683. Park KS, Pang B, Park SJ, Lee YG, Bae JY, Park S, Kim I and Kim SJ. (2011) Identification and functional characterization of ion channels in CD34(+) hematopoietic stem cells from human peripheral blood. Mol Cells 32: 181-8 [PMID:21638203]

684. Park U, Vastani N, Guan Y, Raja SN, Koltzenburg M and Caterina MJ. (2011) TRP vanilloid 2 knock-out mice are susceptible to perinatal lethality but display normal thermal and mechanical nociception. J Neurosci 31: 11425-36 [PMID:21832173]

685. Parnas M, Peters M, Dadon D, Lev S, Vertkin I, Slutsky I and Minke B. (2009) Carvacrol is a novel inhibitor of Drosophila TRPL and mammalian TRPM7 channels. Cell Calcium 45: 300-9 [PMID:19135721]

686. Patapoutian A and Macpherson L. (2006) Channeling pain. Nat Med 12: 506-7 [PMID:16675993]

687. Patel A, Sharif-Naeini R, Folgering JR, Bichet D, Duprat F and Honoré E. (2010) Canonical TRP channels and mechanotransduction: from physiology to disease states. Pflugers Arch 460: 57181 [PMID:20490539] 
688. Paulsen CE, Armache JP, Gao Y, Cheng Y and Julius D. (2015) Structure of the TRPA1 ion channel suggests regulatory mechanisms. Nature 520: 511-7 [PMID:25855297]

689. Pedersen SF, Owsianik G and Nilius B. (2005) TRP channels: an overview. Cell Calcium 38: 23352 [PMID:16098585]

690. Pei Y, Wang K, Kasenda M, Paterson AD, Liang Y, Huang E, Lian J, Rogovea E, Somlo S and St George-Hyslop P. (1998) A novel frameshift mutation induced by an adenosine insertion in the polycystic kidney disease 2 (PKD2) gene. Kidney Int 53: 1127-32 [PMID:9573526]

691. Pei Y, Watnick T, He N, Wang K, Liang Y, Parfrey P, Germino G and St George-Hyslop P. (1999) Somatic PKD2 mutations in individual kidney and liver cysts support a "two-hit" model of cystogenesis in type 2 autosomal dominant polycystic kidney disease. J Am Soc Nephrol 10: 1524-9 [PMID:10405208]

692. Peier AM, Moqrich A, Hergarden AC, Reeve AJ, Andersson DA, Story GM, Earley TJ, Dragoni I, McIntyre P and Bevan S et al.. (2002) A TRP channel that senses cold stimuli and menthol. Cell 108: 705-15 [PMID:11893340]

693. Peier AM, Reeve AJ, Andersson DA, Moqrich A, Earley TJ, Hergarden AC, Story GM, Colley S, Hogenesch JB and McIntyre P et al.. (2002) A heat-sensitive TRP channel expressed in keratinocytes. Science 296: 2046-9 [PMID:12016205]

694. Pelucchi B, Aguiari G, Pignatelli A, Manzati E, Witzgall R, Del Senno L and Belluzzi O. (2006) Nonspecific cation current associated with native polycystin-2 in HEK-293 cells. J Am Soc Nephrol 17: 388-97 [PMID:16396967]

695. Peng JB, Brown EM and Hediger MA. (2001) Structural conservation of the genes encoding CaT1, CaT2, and related cation channels. Genomics 76: 99-109 [PMID:11549322]

696. Peng JB, Chen XZ, Berger UV, Vassilev PM, Brown EM and Hediger MA. (2000) A rat kidneyspecific calcium transporter in the distal nephron. J Biol Chem 275: 28186-94 [PMID:10875938]

697. Peng JB, Chen XZ, Berger UV, Vassilev PM, Tsukaguchi H, Brown EM and Hediger MA. (1999) Molecular cloning and characterization of a channel-like transporter mediating intestinal calcium absorption. J Biol Chem 274: 22739-46 [PMID:10428857]

698. Peng JB, Chen XZ, Berger UV, Weremowicz S, Morton CC, Vassilev PM, Brown EM and Hediger MA. (2000) Human calcium transport protein CaT1. Biochem Biophys Res Commun 278: 326-32 [PMID:11097838]

699. Peng JB, Zhuang L, Berger UV, Adam RM, Williams BJ, Brown EM, Hediger MA and Freeman MR. (2001) CaT1 expression correlates with tumor grade in prostate cancer. Biochem Biophys Res Commun 282: 729-34 [PMID:11401523]

700. Pennekamp P, Bogdanova N, Wilda M, Markoff A, Hameister H, Horst J and Dworniczak B. (1998) Characterization of the murine polycystic kidney disease (Pkd2) gene. Mamm Genome 9: 749-52 [PMID:9716661]

701. Pereira I, Mendes SJ, Pereira DM, Muniz TF, Colares VL, Monteiro CR, Martins MM, Grisotto MA, Monteiro-Neto V and Monteiro SG et al.. (2017) Transient Receptor Potential Ankyrin 1 Channel Expression on Peripheral Blood Leukocytes from Rheumatoid Arthritic Patients and Correlation with Pain and Disability. Front Pharmacol 8: 53 [PMID:28239353]

702. Perez-Ortega I, Moniche-Alvarez F, Jimenez-Hernandez MD and Gonzalez-Marcos JR. (2012) [Cardioembolic stroke in atrial fibrillation and new anticoagulation criteria: a therapeutic dare]. Rev Neurol 55: 74-80 [PMID:22760766]

703. Perraud AL, Fleig A, Dunn CA, Bagley LA, Launay P, Schmitz C, Stokes AJ, Zhu Q, Bessman MJ, Penner R, Kinet JP and Scharenberg AM. (2001) ADP-ribose gating of the calcium-permeable LTRPC2 channel revealed by Nudix motif homology. Nature 411: 595-9 [PMID:11385575]

704. Perraud AL, Schmitz C and Scharenberg AM. (2003) TRPM2 Ca2+ permeable cation channels: from gene to biological function. Cell Calcium 33: 519-31 [PMID:12765697]

705. Petrus M, Peier AM, Bandell M, Hwang SW, Huynh T, Olney N, Jegla T and Patapoutian A. (2007) A role of TRPA1 in mechanical hyperalgesia is revealed by pharmacological inhibition. Mol Pain 3: 40 [PMID:18086313]

706. Peyrot des Gachons C, Uchida K, Bryant B, Shima A, Sperry JB, Dankulich-Nagrudny L, Tominaga M, Smith 3rd AB, Beauchamp GK and Breslin PA. (2011) Unusual pungency from extra-virgin olive oil is attributable to restricted spatial expression of the receptor of oleocanthal. J Neurosci 31: 999-1009 [PMID:21248124]

707. Phelan KD, Shwe UT, Abramowitz J, Wu H, Rhee SW, Howell MD, Gottschall PE, Freichel M, Flockerzi V and Birnbaumer L et al.. (2013) Canonical transient receptor channel 5 (TRPC5) and TRPC1/4 contribute to seizure and excitotoxicity by distinct cellular mechanisms. Mol Pharmacol 83: 429-38 [PMID:23188715]

708. Phelps CB, Wang RR, Choo SS and Gaudet R. (2010) Differential regulation of TRPV1, TRPV3, and TRPV4 sensitivity through a conserved binding site on the ankyrin repeat domain. J Biol Chem 285: 731-40 [PMID:19864432]

709. Philipp S, Hambrecht J, Braslavski L, Schroth G, Freichel M, Murakami M, Cavalié A and Flockerzi V. (1998) A novel capacitative calcium entry channel expressed in excitable cells. EMBO J 17: 4274-82 [PMID:9687496] 
710. Pingle SC, Matta JA and Ahern GP. (2007) Capsaicin receptor: TRPV1 a promiscuous TRP channel. Handb Exp Pharmacol: 155-71 [PMID:17217056]

711. PKD Foundation. Autosomal Dominant Polycystic Kidney Disease Mutation Database: PKDB

712. Plant TD. (2014) TRPs in mechanosensing and volume regulation. Handb Exp Pharmacol 223: 743-66 [PMID:24961968]

713. Plant TD and Schaefer M. (2003) TRPC4 and TRPC5: receptor-operated Ca2+-permeable nonselective cation channels. Cell Calcium 33: 441-50 [PMID:12765689]

714. Plesch E, Chen CC, Butz E, Scotto Rosato A, Krogsaeter EK, Yinan H, Bartel K, Keller M, Robaa D and Teupser D et al.. (2018) Selective agonist of TRPML2 reveals direct role in chemokine release from innate immune cells. Elife 7 [PMID:30479274]

715. Pollastro F, Taglialatela-Scafati O, Allarà M, Muñoz E, Di Marzo V, De Petrocellis L and Appendino G. (2011) Bioactive prenylogous cannabinoid from fiber hemp (Cannabis sativa). $J$ Nat Prod 74: 2019-22 [PMID:21902175]

716. Poole DP, Amadesi S, Veldhuis NA, Abogadie FC, Lieu T, Darby W, Liedtke W, Lew MJ, McIntyre P and Bunnett NW. (2013) Protease-activated receptor 2 (PAR2) protein and transient receptor potential vanilloid 4 (TRPV4) protein coupling is required for sustained inflammatory signaling. $J$ Biol Chem 288: 5790-802 [PMID:23288842]

717. Poole DP, Pelayo JC, Cattaruzza F, Kuo YM, Gai G, Chiu JV, Bron R, Furness JB, Grady EF and Bunnett NW. (2011) Transient receptor potential ankyrin 1 is expressed by inhibitory motoneurons of the mouse intestine. Gastroenterology 141: 565-75, 575.e1-4 [PMID:21689654]

718. Potier M and Trebak M. (2008) New developments in the signaling mechanisms of the storeoperated calcium entry pathway. Pflugers Arch 457: 405-15 [PMID:18536932]

719. Pozsgai G, Bodkin JV, Graepel R, Bevan S, Andersson DA and Brain SD. (2010) Evidence for the pathophysiological relevance of TRPA1 receptors in the cardiovascular system in vivo. Cardiovasc Res 87: 760-8 [PMID:20442136]

720. Prawitt D, Enklaar T, Klemm G, Gärtner B, Spangenberg C, Winterpacht A, Higgins M, Pelletier $\mathrm{J}$ and Zabel B. (2000) Identification and characterization of MTR1, a novel gene with homology to melastatin (MLSN1) and the trp gene family located in the BWS-WT2 critical region on chromosome 11p15.5 and showing allele-specific expression. Hum Mol Genet 9: 203-16 [PMID:10607831]

721. Prawitt D, Monteilh-Zoller MK, Brixel L, Spangenberg C, Zabel B, Fleig A and Penner R. (2003) TRPM5 is a transient Ca2+-activated cation channel responding to rapid changes in $[\mathrm{Ca} 2+] \mathrm{i}$. Proc Natl Acad Sci USA 100: 15166-71 [PMID:14634208]

722. Prescott ED and Julius D. (2003) A modular PIP2 binding site as a determinant of capsaicin receptor sensitivity. Science 300: 1284-8 [PMID:12764195]

723. Puertollano R and Kiselyov K. (2009) TRPMLs: in sickness and in health. Am J Physiol Renal Physiol 296: F1245-54 [PMID:19158345]

724. Puram SV, Riccio A, Koirala S, Ikeuchi Y, Kim AH, Corfas G and Bonni A. (2011) A TRPC5regulated calcium signaling pathway controls dendrite patterning in the mammalian brain. Genes Dev 25: 2659-73 [PMID:22135323]

725. Purhonen AK, Louhivuori LM, Kiehne K, Kerman KE and Herzig KH. (2008) TRPA1 channel activation induces cholecystokinin release via extracellular calcium. FEBS Lett 582: 229-32 [PMID:18082143]

726. Putney JW. (2005) Physiological mechanisms of TRPC activation. Pflugers Arch 451: 29-34 [PMID:16133266]

727. Pérez CA, Huang L, Rong M, Kozak JA, Preuss AK, Zhang H, Max M and Margolskee RF. (2002) A transient receptor potential channel expressed in taste receptor cells. Nat Neurosci 5: 116976 [PMID:12368808]

728. Qian F, Germino FJ, Cai Y, Zhang X, Somlo S and Germino GG. (1997) PKD1 interacts with PKD2 through a probable coiled-coil domain. Nat Genet 16: 179-83 [PMID:9171830]

729. Qian F and Noben-Trauth K. (2005) Cellular and molecular function of mucolipins (TRPML) and polycystin 2 (TRPP2). Pflugers Arch 451: 277-85 [PMID:15971078]

730. Qian Q, Hunter LW, Li M, Marin-Padilla M, Prakash YS, Somlo S, Harris PC, Torres VE and Sieck GC. (2003) Pkd2 haploinsufficiency alters intracellular calcium regulation in vascular smooth muscle cells. Hum Mol Genet 12: 1875-80 [PMID:12874107]

731. Qin N, Neeper MP, Liu Y, Hutchinson TL, Lubin ML and Flores CM. (2008) TRPV2 is activated by cannabidiol and mediates CGRP release in cultured rat dorsal root ganglion neurons. $J$ Neurosci 28: 6231-8 [PMID:18550765]

732. Qin X, Yue Z, Sun B, Yang W, Xie J, Ni E, Feng Y, Mahmood R, Zhang Y and Yue L. (2013) Sphingosine and FTY720 are potent inhibitors of the transient receptor potential melastatin 7 (TRPM7) channels. Br J Pharmacol 168: 1294-312 [PMID:23145923]

733. Qu C, Ding M, Zhu Y, Lu Y, Du J, Miller M, Tian J, Zhu J, Xu J and Wen M et al.. (2017) Pyrazolopyrimidines as Potent Stimulators for Transient Receptor Potential Canonical 3/6/7 Channels. J Med Chem 60: 4680-4692 [PMID:28395140]

734. Quallo T, Alkhatib O, Gentry C, Andersson DA and Bevan S. (2017) G protein $\beta \gamma$ subunits inhibit 
TRPM3 ion channels in sensory neurons. Elife 6 [PMID:28826490]

735. Raemdonck K, de Alba J, Birrell MA, Grace M, Maher SA, Irvin CG, Fozard JR, O'Byrne PM and Belvisi MG. (2012) A role for sensory nerves in the late asthmatic response. Thorax 67: 19-25 [PMID:21841185]

736. Ramsey IS, Delling M and Clapham DE. (2006) An introduction to TRP channels. Annu Rev Physiol 68: 619-47 [PMID:16460286]

737. Reid G. (2005) ThermoTRP channels and cold sensing: what are they really up to? Pflugers Arch 451: 250-63 [PMID:16075243]

738. Reiser J, Polu KR, Möller CC, Kenlan P, Altintas MM, Wei C, Faul C, Herbert S, Villegas I and Avila-Casado C et al.. (2005) TRPC6 is a glomerular slit diaphragm-associated channel required for normal renal function. Nat Genet 37: 739-44 [PMID:15924139]

739. Reynolds DM, Hayashi T, Cai Y, Veldhuisen B, Watnick TJ, Lens XM, Mochizuki T, Qian F, Maeda Y and Li L et al.. (1999) Aberrant splicing in the PKD2 gene as a cause of polycystic kidney disease. J Am Soc Nephrol 10: 2342-51 [PMID:10541293]

740. Riccio A, Li Y, Moon J, Kim KS, Smith KS, Rudolph U, Gapon S, Yao GL, Tsvetkov E and Rodig SJ et al.. (2009) Essential role for TRPC5 in amygdala function and fear-related behavior. Cell 137: 761-72 [PMID:19450521]

741. Riccio A, Mattei C, Kelsell RE, Medhurst AD, Calver AR, Randall AD, Davis JB, Benham CD and Pangalos MN. (2002) Cloning and functional expression of human short TRP7, a candidate protein for store-operated Ca2+ influx. J Biol Chem 277: 12302-9 [PMID:11805119]

742. Riccio A, Medhurst AD, Mattei C, Kelsell RE, Calver AR, Randall AD, Benham CD and Pangalos MN. (2002) mRNA distribution analysis of human TRPC family in CNS and peripheral tissues. Brain Res Mol Brain Res 109: 95-104 [PMID:12531519]

743. Richter JM, Schaefer M and Hill K. (2014) Clemizole hydrochloride is a novel and potent inhibitor of transient receptor potential channel TRPC5. Mol Pharmacol 86: 514-21 [PMID:25140002]

744. Richter JM, Schaefer M and Hill K. (2014) Riluzole activates TRPC5 channels independently of PLC activity. Br J Pharmacol 171: 158-70 [PMID:24117252]

745. Rock MJ, Prenen J, Funari VA, Funari TL, Merriman B, Nelson SF, Lachman RS, Wilcox WR, Reyno S and Quadrelli R et al.. (2008) Gain-of-function mutations in TRPV4 cause autosomal dominant brachyolmia. Nat Genet 40: 999-1003 [PMID:18587396]

746. Roedding AS, Gao AF, Au-Yeung W, Scarcelli T, Li PP and Warsh JJ. (2012) Effect of oxidative stress on TRPM2 and TRPC3 channels in B lymphoblast cells in bipolar disorder. Bipolar Disord 14: 151-61 [PMID:22420591]

747. Rohacs T. (2009) Phosphoinositide regulation of non-canonical transient receptor potential channels. Cell Calcium 45: 554-65 [PMID:19376575]

748. Rohacs T and Nilius B. (2007) Regulation of transient receptor potential (TRP) channels by phosphoinositides. Pflugers Arch 455: 157-68 [PMID:17479281]

749. Rohács T, Lopes CM, Michailidis I and Logothetis DE. (2005) PI(4,5)P2 regulates the activation and desensitization of TRPM8 channels through the TRP domain. Nat Neurosci 8: 626-34 [PMID:15852009]

750. Rosker C, Graziani A, Lukas M, Eder P, Zhu MX, Romanin C and Groschner K. (2004) Ca(2+) signaling by TRPC3 involves $\mathrm{Na}(+)$ entry and local coupling to the $\mathrm{Na}(+) / \mathrm{Ca}(2+)$ exchanger. $J$ Biol Chem 279: 13696-704 [PMID:14736881]

751. Rubaiy HN. (2019) Treasure troves of pharmacological tools to study transient receptor potential canonical 1/4/5 channels. Br J Pharmacol 176: 832-846 [PMID:30656647]

752. Rubaiy HN, Ludlow MJ, Henrot M, Gaunt HJ, Miteva K, Cheung SY, Tanahashi Y, Hamzah N, Musialowski KE and Blythe NM et al.. (2017) Picomolar, selective, and subtype-specific smallmolecule inhibition of TRPC1/4/5 channels. J Biol Chem 292: 8158-8173 [PMID:28325835]

753. Rubaiy HN, Ludlow MJ, Siems K, Norman K, Foster R, Wolf D, Beutler JA and Beech DJ. (2018) Tonantzitlolone is a nanomolar potency activator of transient receptor potential canonical 1/4/5 channels. Br J Pharmacol 175: 3361-3368 [PMID:29859013]

754. Rundle DR, Gorbsky G and Tsiokas L. (2004) PKD2 interacts and co-localizes with mDia1 to mitotic spindles of dividing cells: role of mDia1 IN PKD2 localization to mitotic spindles. $J$ Biol Chem 279: 29728-39 [PMID:15123714]

755. Runnels LW, Yue L and Clapham DE. (2001) TRP-PLIK, a bifunctional protein with kinase and ion channel activities. Science 291: 1043-7 [PMID:11161216]

756. Runnels LW, Yue L and Clapham DE. (2002) The TRPM7 channel is inactivated by PIP(2) hydrolysis. Nat Cell Biol 4: 329-36 [PMID:11941371]

757. Rutter AR, Ma QP, Leveridge M and Bonnert TP. (2005) Heteromerization and colocalization of TrpV1 and TrpV2 in mammalian cell lines and rat dorsal root ganglia. Neuroreport 16: 1735-9 [PMID:16237318]

758. Ryckmans T, Aubdool AA, Bodkin JV, Cox P, Brain SD, Dupont T, Fairman E, Hashizume Y, Ishii $\mathrm{N}$ and Kato T et al.. (2011) Design and pharmacological evaluation of PF-4840154, a nonelectrophilic reference agonist of the TrpA1 channel. Bioorg Med Chem Lett 21: 4857-9 
[PMID:21741838]

759. Ryskamp DA, Witkovsky P, Barabas P, Huang W, Koehler C, Akimov NP, Lee SH, Chauhan S, Xing W and Rentería RC et al.. (2011) The polymodal ion channel transient receptor potential vanilloid 4 modulates calcium flux, spiking rate, and apoptosis of mouse retinal ganglion cells. $J$ Neurosci 31: 7089-101 [PMID:21562271]

760. Sabourin J, Lamiche C, Vandebrouck A, Magaud C, Rivet J, Cognard C, Bourmeyster N and Constantin B. (2009) Regulation of TRPC1 and TRPC4 cation channels requires an alpha1syntrophin-dependent complex in skeletal mouse myotubes. J Biol Chem 284: 36248-61 [PMID:19812031]

761. Sah R, Mesirca P, Mason X, Gibson W, Bates-Withers C, Van den Boogert M, Chaudhuri D, Pu WT, Mangoni ME and Clapham DE.. (2013) Timing of myocardial trpm7 deletion during cardiogenesis variably disrupts adult ventricular function, conduction, and repolarization. Circulation 128: 101-114 [PMID:23734001]

762. Sah R, Mesirca P, Van den Boogert M, Rosen J, Mably J, Mangoni ME and Clapham DE. (2013) Ion channel-kinase TRPM7 is required for maintaining cardiac automaticity. Proc Natl Acad Sci USA 110: E3037-46 [PMID:23878236]

763. Sala-Rabanal M, Wang S and Nichols CG. (2012) On potential interactions between nonselective cation channel TRPM4 and sulfonylurea receptor SUR1. J Biol Chem 287: 8746-56 [PMID:22291026]

764. Salido GM, Sage SO and Rosado JA. (2009) TRPC channels and store-operated Ca(2+) entry. Biochim Biophys Acta 1793: 223-30 [PMID:19061922]

765. Samie M, Wang X, Zhang X, Goschka A, Li X, Cheng X, Gregg E, Azar M, Zhuo Y and Garrity AG et al.. (2013) A TRP channel in the lysosome regulates large particle phagocytosis via focal exocytosis. Dev Cell 26: 511-24 [PMID:23993788]

766. Samie MA, Grimm C, Evans JA, Curcio-Morelli C, Heller S, Slaugenhaupt SA and Cuajungco MP. (2009) The tissue-specific expression of TRPML2 (MCOLN-2) gene is influenced by the presence of TRPML1. Pflugers Arch 459: 79-91 [PMID:19763610]

767. Samivel R, Kim DW, Son HR, Rhee YH, Kim EH, Kim JH, Bae JS, Chung YJ, Chung PS and Raz E et al.. (2016) The role of TRPV1 in the CD4+ T cell-mediated inflammatory response of allergic rhinitis. Oncotarget 7: 148-60 [PMID:26700618]

768. Sano Y, Inamura K, Miyake A, Mochizuki S, Yokoi H, Matsushime H and Furuichi K. (2001) Immunocyte Ca2+ influx system mediated by LTRPC2. Science 293: 1327-30 [PMID:11509734]

769. Satoh S, Tanaka H, Ueda Y, Oyama J, Sugano M, Sumimoto H, Mori Y and Makino N. (2007) Transient receptor potential (TRP) protein 7 acts as a G protein-activated Ca2+ channel mediating angiotensin II-induced myocardial apoptosis. Mol Cell Biochem 294: 205-15 [PMID:16838106]

770. Saunders CI, Kunde DA, Crawford A and Geraghty DP. (2007) Expression of transient receptor potential vanilloid 1 (TRPV1) and 2 (TRPV2) in human peripheral blood. Mol Immunol 44: 142935 [PMID:16777226]

771. Sawada Y, Hosokawa H, Matsumura K and Kobayashi S. (2008) Activation of transient receptor potential ankyrin 1 by hydrogen peroxide. Eur J Neurosci 27: 1131-42 [PMID:18364033]

772. Schaefer M, Plant TD, Obukhov AG, Hofmann T, Gudermann T and Schultz G. (2000) Receptormediated regulation of the nonselective cation channels TRPC4 and TRPC5. J Biol Chem 275: 17517-26 [PMID:10837492]

773. Schappe MS, Szteyn K, Stremska ME, Mendu SK, Downs TK, Seegren PV, Mahoney MA, Dixit S, Krupa JK and Stipes EJ et al.. (2018) Chanzyme TRPM7 Mediates the $\mathrm{Ca}^{2+}$ Influx Essential for Lipopolysaccharide-Induced Toll-Like Receptor 4 Endocytosis and Macrophage Activation. Immunity 48: 59-74.e5 [PMID:29343440]

774. Scharenberg AM. (2005) TRPM2 and TRPM7: channel/enzyme fusions to generate novel intracellular sensors. Pflugers Arch 451: 220-7 [PMID:16001276]

775. Schattling B, Steinbach K, Thies E, Kruse M, Menigoz A, Ufer F, Flockerzi V, Brück W, Pongs O and Vennekens R et al.. (2012) TRPM4 cation channel mediates axonal and neuronal degeneration in experimental autoimmune encephalomyelitis and multiple sclerosis. Nat Med 18: 1805-11 [PMID:23160238]

776. Schenkel LB, Olivieri PR, Boezio AA, Deak HL, Emkey R, Graceffa RF, Gunaydin H, GuzmanPerez A, Lee JH and Teffera Y et al.. (2016) Optimization of a Novel Quinazolinone-Based Series of Transient Receptor Potential A1 (TRPA1) Antagonists Demonstrating Potent in Vivo Activity. $J$ Med Chem 59: 2794-809 [PMID:26942860]

777. Schiller Y. (2004) Activation of a calcium-activated cation current during epileptiform discharges and its possible role in sustaining seizure-like events in neocortical slices. $J$ Neurophysiol 92: 862-72 [PMID:15277598]

778. Schindl R, Fritsch R, Jardin I, Frischauf I, Kahr H, Muik M, Riedl MC, Groschner K and Romanin C. (2012) Canonical transient receptor potential (TRPC) 1 acts as a negative regulator for vanilloid TRPV6-mediated Ca2+ influx. J Biol Chem 287: 35612-20 [PMID:22932896]

779. Schleifer H, Doleschal B, Lichtenegger M, Oppenrieder R, Derler I, Frischauf I, Glasnov TN, 
Kappe CO, Romanin C and Groschner K. (2012) Novel pyrazole compounds for pharmacological discrimination between receptor-operated and store-operated $\mathrm{Ca}(2+)$ entry pathways. $\mathrm{BrJ}$ Pharmacol 167: 1712-22 [PMID:22862290]

780. Schlingmann KP, Sassen MC, Weber S, Pechmann U, Kusch K, Pelken L, Lotan D, Syrrou M, Prebble JJ and Cole DE et al.. (2005) Novel TRPM6 mutations in 21 families with primary hypomagnesemia and secondary hypocalcemia. J Am Soc Nephrol 16: 3061-9 [PMID:16107578]

781. Schlingmann KP, Weber S, Peters M, Niemann Nejsum L, Vitzthum H, Klingel K, Kratz M, Haddad E, Ristoff E and Dinour D et al.. (2002) Hypomagnesemia with secondary hypocalcemia is caused by mutations in TRPM6, a new member of the TRPM gene family. Nat Genet 31: 16670 [PMID:12032568]

782. Schmiege P, Fine M, Blobel G and Li X. (2017) Human TRPML1 channel structures in open and closed conformations. Nature 550: 366-370 [PMID:29019983]

783. Schmitz C, Dorovkov MV, Zhao X, Davenport BJ, Ryazanov AG and Perraud AL. (2005) The channel kinases TRPM6 and TRPM7 are functionally nonredundant. J Biol Chem 280: 37763-71 [PMID:16150690]

784. Schoeber JP, Topala CN, Lee KP, Lambers TT, Ricard G, van der Kemp AW, Huynen MA, Hoenderop JG and Bindels RJ. (2008) Identification of Nipsnap1 as a novel auxiliary protein inhibiting TRPV6 activity. Pflugers Arch 457: 91-101 [PMID:18392847]

785. Schulze A, Oehler B, Urban N, Schaefer M and Hill K. (2013) Apomorphine is a bimodal modulator of TRPA1 channels. Mol Pharmacol 83: 542-51 [PMID:23220749]

786. Schumacher MA and Eilers H. (2010) TRPV1 splice variants: structure and function. Front Biosci 15: 872-82 [PMID:20515731]

787. Schwartz ES, Christianson JA, Chen X, La JH, Davis BM, Albers KM and Gebhart GF. (2011) Synergistic role of TRPV1 and TRPA1 in pancreatic pain and inflammation. Gastroenterology 140: 1283-1291.e1-2 [PMID:21185837]

788. Schwartz FW. (1987) [Medical orientation data--a challenge to public health]. Offentl Gesundheitswes 49: 229-33 [PMID:2955270]

789. Sel S, Rost BR, Yildirim AO, Sel B, Kalwa H, Fehrenbach H, Renz H, Gudermann T and Dietrich A. (2008) Loss of classical transient receptor potential 6 channel reduces allergic airway response. Clin Exp Allergy 38: 1548-58 [PMID:18631347]

790. Semtner M, Schaefer M, Pinkenburg O and Plant TD. (2007) Potentiation of TRPC5 by protons. $J$ Biol Chem 282: 33868-78 [PMID:17884814]

791. Seo K, Rainer PP, Shalkey Hahn V, Lee DI, Jo SH, Andersen A, Liu T, Xu X, Willette RN and Lepore JJ et al.. (2014) Combined TRPC3 and TRPC6 blockade by selective small-molecule or genetic deletion inhibits pathological cardiac hypertrophy. Proc Natl Acad Sci USA 111: 1551-6 [PMID:24453217]

792. Serafini N, Dahdah A, Barbet G, Demion M, Attout T, Gautier G, Arcos-Fajardo M, Souchet H, Jouvin MH and Vrtovsnik F et al.. (2012) The TRPM4 channel controls monocyte and macrophage, but not neutrophil, function for survival in sepsis. J Immunol 189: 3689-99 [PMID:22933633]

793. Sharma S and Hopkins CR. (2019) Review of Transient Receptor Potential Canonical (TRPC5) Channel Modulators and Diseases. J Med Chem 62: 7589-7602 [PMID:30943030]

794. Shen D, Wang X, Li X, Zhang X, Yao Z, Dibble S, Dong XP, Yu T, Lieberman AP and Showalter HD et al.. (2012) Lipid storage disorders block lysosomal trafficking by inhibiting a TRP channel and lysosomal calcium release. Nat Commun 3: 731 [PMID:22415822]

795. Sherkheli MA, Vogt-Eisele AK, Bura D, Beltrán Márques LR, Gisselmann G and Hatt H. (2010) Characterization of selective TRPM8 ligands and their structure activity response (S.A.R) relationship. J Pharm Pharm Sci 13: 242-53 [PMID:20816009]

796. Shi J, Mori E, Mori Y, Mori M, Li J, Ito Y and Inoue R. (2004) Multiple regulation by calcium of murine homologues of transient receptor potential proteins TRPC6 and TRPC7 expressed in HEK293 cells. J Physiol (Lond.) 561: 415-32 [PMID:15579537]

797. Shiba T, Maruyama T, Kurohane K, Iwasaki Y, Watanabe T and Imai Y. (2009) TRPA1 and TRPV1 activation is a novel adjuvant effect mechanism in contact hypersensitivity. $J$ Neuroimmunol 207: 66-74 [PMID:19135264]

798. Shibasaki K, Murayama N, Ono K, Ishizaki Y and Tominaga M. (2010) TRPV2 enhances axon outgrowth through its activation by membrane stretch in developing sensory and motor neurons. J Neurosci 30: 4601-12 [PMID:20357111]

799. Shimizu T, Janssens A, Voets T and Nilius B. (2009) Regulation of the murine TRPP3 channel by voltage, $\mathrm{pH}$, and changes in cell volume. Pflugers Arch 457: 795-807 [PMID:18663466]

800. Shimizu T, Owsianik G, Freichel M, Flockerzi V, Nilius B and Vennekens R. (2009) TRPM4 regulates migration of mast cells in mice. Cell Calcium 45: 226-32 [PMID:19046767]

801. Shimosato G, Amaya F, Ueda M, Tanaka Y, Decosterd I and Tanaka M. (2005) Peripheral inflammation induces up-regulation of TRPV2 expression in rat DRG. Pain 119: 225-32 [PMID:16298071]

802. Sidhaye VK, Güler AD, Schweitzer KS, D'Alessio F, Caterina MJ and King LS. (2006) Transient 
receptor potential vanilloid 4 regulates aquaporin-5 abundance under hypotonic conditions. Proc Natl Acad Sci USA 103: 4747-52 [PMID:16537379]

803. Siemens J, Zhou S, Piskorowski R, Nikai T, Lumpkin EA, Basbaum AI, King D and Julius D. (2006) Spider toxins activate the capsaicin receptor to produce inflammatory pain. Nature $\mathbf{4 4 4}$ : 208-12 [PMID:17093448]

804. Simard JM, Chen M, Tarasov KV, Bhatta S, Ivanova S, Melnitchenko L, Tsymbalyuk N, West GA and Gerzanich V. (2006) Newly expressed SUR1-regulated NC(Ca-ATP) channel mediates cerebral edema after ischemic stroke. Nat Med 12: 433-40 [PMID:16550187]

805. Singh BB, Liu X, Tang J, Zhu MX and Ambudkar IS. (2002) Calmodulin regulates Ca(2+)dependent feedback inhibition of store-operated $\mathrm{Ca}(2+)$ influx by interaction with a site in the $\mathrm{C}$ terminus of TrpC1. Mol Cell 9: 739-50 [PMID:11983166]

806. Sinkins WG, Goel M, Estacion M and Schilling WP. (2004) Association of immunophilins with mammalian TRPC channels. J Biol Chem 279: 34521-9 [PMID:15199065]

807. Sisignano M, Park CK, Angioni C, Zhang DD, von Hehn C, Cobos EJ, Ghasemlou N, Xu ZZ, Kumaran V and Lu R et al.. (2012) 5,6-EET is released upon neuronal activity and induces mechanical pain hypersensitivity via TRPA1 on central afferent terminals. J Neurosci 32: 636472 [PMID:22553041]

808. Slaugenhaupt SA. (2002) The molecular basis of mucolipidosis type IV. Curr Mol Med 2: 445-50 [PMID:12125810]

809. Smart D, Gunthorpe MJ, Jerman JC, Nasir S, Gray J, Muir AI, Chambers JK, Randall AD and Davis JB. (2000) The endogenous lipid anandamide is a full agonist at the human vanilloid receptor (hVR1). Br J Pharmacol 129: 227-30 [PMID:10694225]

810. Smart D, Jerman JC, Gunthorpe MJ, Brough SJ, Ranson J, Cairns W, Hayes PD, Randall AD and Davis JB. (2001) Characterisation using FLIPR of human vanilloid VR1 receptor pharmacology. Eur J Pharmacol 417: 51-8 [PMID:11301059]

811. Smith GD, Gunthorpe MJ, Kelsell RE, Hayes PD, Reilly P, Facer P, Wright JE, Jerman JC, Walhin JP and Ooi L et al.. (2002) TRPV3 is a temperature-sensitive vanilloid receptor-like protein. Nature 418: 186-90 [PMID:12077606]

812. Smith MA, Herson PS, Lee K, Pinnock RD and Ashford ML. (2003) Hydrogen-peroxide-induced toxicity of rat striatal neurones involves activation of a non-selective cation channel. J Physiol (Lond.) 547: 417-25 [PMID:12562896]

813. Smith PL, Maloney KN, Pothen RG, Clardy J and Clapham DE. (2006) Bisandrographolide from Andrographis paniculata activates TRPV4 channels. J Biol Chem 281: 29897-904 [PMID:16899456]

814. Soboloff J, Spassova M, Xu W, He LP, Cuesta N and Gill DL. (2005) Role of endogenous TRPC6 channels in Ca2+ signal generation in A7r5 smooth muscle cells. J Biol Chem 280: 39786-94 [PMID:16204251]

815. Sokabe T, Fukumi-Tominaga T, Yonemura S, Mizuno A and Tominaga M. (2010) The TRPV4 channel contributes to intercellular junction formation in keratinocytes. J Biol Chem 285: 18749-58 [PMID:20413591]

816. Song X, Zhao Y, Narcisse L, Duffy H, Kress Y, Lee S and Brosnan CF. (2005) Canonical transient receptor potential channel 4 (TRPC4) co-localizes with the scaffolding protein ZO-1 in human fetal astrocytes in culture. Glia 49: 418-29 [PMID:15540229]

817. Spehr J, Hagendorf S, Weiss J, Spehr M, Leinders-Zufall T and Zufall F. (2009) Ca2+ -calmodulin feedback mediates sensory adaptation and inhibits pheromone-sensitive ion channels in the vomeronasal organ. J Neurosci 29: 2125-35 [PMID:19228965]

818. Staaf S, Oerther S, Lucas G, Mattsson JP and Ernfors P. (2009) Differential regulation of TRP channels in a rat model of neuropathic pain. Pain 144: 187-99 [PMID:19446956]

819. Stallmeyer B, Zumhagen S, Denjoy I, Duthoit G, Hébert JL, Ferrer X, Maugenre S, Schmitz W, Kirchhefer U and Schulze-Bahr E et al.. (2012) Mutational spectrum in the $\mathrm{Ca}(2+)$--activated cation channel gene TRPM4 in patients with cardiac conductance disturbances. Hum Mutat 33: 109-17 [PMID:21887725]

820. Stamboulian S, Moutin MJ, Treves S, Pochon N, Grunwald D, Zorzato F, De Waard M, Ronjat M and Arnoult C. (2005) Junctate, an inositol 1,4,5-triphosphate receptor associated protein, is present in rodent sperm and binds TRPC2 and TRPC5 but not TRPC1 channels. Dev Biol 286: 326-37 [PMID:16153633]

821. Starkus JG, Fleig A and Penner R. (2010) The calcium-permeable non-selective cation channel TRPM2 is modulated by cellular acidification. J Physiol (Lond.) 588: 1227-40 [PMID:20194125]

822. Starowicz K, Nigam S and Di Marzo V. (2007) Biochemistry and pharmacology of endovanilloids. Pharmacol Ther 114: 13-33 [PMID:17349697]

823. Stein AT, Ufret-Vincenty CA, Hua L, Santana LF and Gordon SE. (2006) Phosphoinositide 3kinase binds to TRPV1 and mediates NGF-stimulated TRPV1 trafficking to the plasma membrane. J Gen Physiol 128: 509-22 [PMID:17074976]

824. Stein RJ, Santos S, Nagatomi J, Hayashi Y, Minnery BS, Xavier M, Patel AS, Nelson JB, Futrell WJ and Yoshimura N et al.. (2004) Cool (TRPM8) and hot (TRPV1) receptors in the bladder and 
male genital tract. J Urol 172: 1175-8 [PMID:15311065]

825. Stiber JA, Tang Y, Li T and Rosenberg PB. (2012) Cytoskeletal regulation of TRPC channels in the cardiorenal system. Curr Hypertens Rep 14: 492-7 [PMID:23054893]

826. Stokes A, Wakano C, Koblan-Huberson M, Adra CN, Fleig A and Turner H. (2006) TRPA1 is a substrate for de-ubiquitination by the tumor suppressor CYLD. Cell Signal 18: 1584-94 [PMID:16500080]

827. Stokes AJ, Shimoda LM, Koblan-Huberson M, Adra CN and Turner H. (2004) A TRPV2-PKA signaling module for transduction of physical stimuli in mast cells. J Exp Med 200: 137-47 [PMID:15249591]

828. Stokes AJ, Wakano C, Del Carmen KA, Koblan-Huberson M and Turner H. (2005) Formation of a physiological complex between TRPV2 and RGA protein promotes cell surface expression of TRPV2. J Cell Biochem 94: 669-83 [PMID:15547947]

829. Story GM, Peier AM, Reeve AJ, Eid SR, Mosbacher J, Hricik TR, Earley TJ, Hergarden AC, Andersson DA and Hwang SW et al.. (2003) ANKTM1, a TRP-like channel expressed in nociceptive neurons, is activated by cold temperatures. Cell 112: 819-29 [PMID:12654248]

830. Stotz SC, Vriens J, Martyn D, Clardy J and Clapham DE. (2008) Citral sensing by Transient [corrected] receptor potential channels in dorsal root ganglion neurons. PLOS ONE 3: e2082 [PMID:18461159]

831. Stowers L, Holy TE, Meister M, Dulac C and Koentges G. (2002) Loss of sex discrimination and male-male aggression in mice deficient for TRP2. Science 295: 1493-500 [PMID:11823606]

832. Straub I, Krügel U, Mohr F, Teichert J, Rizun O, Konrad M, Oberwinkler J and Schaefer M. (2013) Flavanones that selectively inhibit TRPM3 attenuate thermal nociception in vivo. Mol Pharmacol 84: 736-50 [PMID:24006495]

833. Straub I, Mohr F, Stab J, Konrad M, Philipp SE, Oberwinkler J and Schaefer M. (2013) Citrus fruit and fabacea secondary metabolites potently and selectively block TRPM3. Br J Pharmacol 168: 1835-50 [PMID:23190005]

834. Straub RH. (2014) TRPV1, TRPA1, and TRPM8 channels in inflammation, energy redirection, and water retention: role in chronic inflammatory diseases with an evolutionary perspective. $J$ Mol Med 92: 925-37 [PMID:24871046]

835. Streng T, Axelsson HE, Hedlund P, Andersson DA, Jordt SE, Bevan S, Andersson KE, Högestätt ED and Zygmunt PM. (2008) Distribution and function of the hydrogen sulfide-sensitive TRPA1 ion channel in rat urinary bladder. Eur Urol 53: 391-9 [PMID:18031925]

836. Stroh O, Freichel M, Kretz O, Birnbaumer L, Hartmann J and Egger V. (2012) NMDA receptordependent synaptic activation of TRPC channels in olfactory bulb granule cells. J Neurosci 32: 5737-46 [PMID:22539836]

837. Strotmann R, Harteneck C, Nunnenmacher K, Schultz G and Plant TD. (2000) OTRPC4, a nonselective cation channel that confers sensitivity to extracellular osmolarity. Nat Cell Biol 2: 695-702 [PMID:11025659]

838. Strotmann R, Schultz G and Plant TD. (2003) Ca2+-dependent potentiation of the nonselective cation channel TRPV4 is mediated by a C-terminal calmodulin binding site. J Biol Chem 278: 26541-9 [PMID:12724311]

839. Strübing C, Krapivinsky G, Krapivinsky L and Clapham DE. (2001) TRPC1 and TRPC5 form a novel cation channel in mammalian brain. Neuron 29: 645-55 [PMID:11301024]

840. Strübing C, Krapivinsky G, Krapivinsky L and Clapham DE. (2003) Formation of novel TRPC channels by complex subunit interactions in embryonic brain. J Biol Chem 278: 39014-9 [PMID:12857742]

841. Su LT, Agapito MA, Li M, Simonson WT, Huttenlocher A, Habas R, Yue L and Runnels LW. (2006) TRPM7 regulates cell adhesion by controlling the calcium-dependent protease calpain. $J$ Biol Chem 281: 11260-70 [PMID:16436382]

842. Su LT, Liu W, Chen HC, González-Pagán O, Habas R and Runnels LW. (2011) TRPM7 regulates polarized cell movements. Biochem J 434: 513-21 [PMID:21208190]

843. Su Q, Hu F, Ge X, Lei J, Yu S, Wang T, Zhou Q, Mei C and Shi Y. (2018) Structure of the human PKD1-PKD2 complex. Science 361 [PMID:30093605]

844. Sugiura T, Bielefeldt K and Gebhart GF. (2007) Mouse colon sensory neurons detect extracellular acidosis via TRPV1. Am J Physiol, Cell Physiol 292: C1768-74 [PMID:17251322]

845. Sukharev S. (2002) Purification of the small mechanosensitive channel of Escherichia coli (MscS): the subunit structure, conduction, and gating characteristics in liposomes. Biophys J 83: 290-8 [PMID:12080120]

846. Sukharev SI, Blount P, Martinac B, Blattner FR and Kung C. (1994) A large-conductance mechanosensitive channel in E. coli encoded by mscL alone. Nature 368: 265-8 [PMID:7511799]

847. Sulk M, Seeliger S, Aubert J, Schwab VD, Cevikbas F, Rivier M, Nowak P, Voegel JJ, Buddenkotte J and Steinhoff M. (2012) Distribution and expression of non-neuronal transient receptor potential (TRPV) ion channels in rosacea. J Invest Dermatol 132: 1253-62 [PMID:22189789]

848. Sun M, Goldin E, Stahl S, Falardeau JL, Kennedy JC, Acierno JS, Bove C, Kaneski CR, Nagle J, 
Bromley MC, Colman M, Schiffmann R and Slaugenhaupt SA. (2000) Mucolipidosis type IV is caused by mutations in a gene encoding a novel transient receptor potential channel. Hum Mol Genet 9: 2471-8 [PMID:11030752]

849. Sun XY, Sun LL, Qi H, Gao Q, Wang GX, Wei NN and Wang K. (2018) Antipruritic Effect of Natural Coumarin Osthole through Selective Inhibition of Thermosensitive TRPV3 Channel in the Skin. Mol Pharmacol 94: 1164-1173 [PMID:30108138]

850. Sundivakkam PC, Kwiatek AM, Sharma TT, Minshall RD, Malik AB and Tiruppathi C. (2009) Caveolin-1 scaffold domain interacts with TRPC1 and IP3R3 to regulate Ca2+ store releaseinduced Ca2+ entry in endothelial cells. Am J Physiol, Cell Physiol 296: C403-13 [PMID:19052258]

851. Sutton KA, Jungnickel MK, Wang Y, Cullen K, Lambert S and Florman HM. (2004) Enkurin is a novel calmodulin and TRPC channel binding protein in sperm. Dev Biol 274: 426-35 [PMID:15385169]

852. Sutton KA, Jungnickel MK, Ward CJ, Harris PC and Florman HM. (2006) Functional characterization of PKDREJ, a male germ cell-restricted polycystin. J Cell Physiol 209: 493-500 [PMID:16883570]

853. Suzuki H, Sasaki E, Nakagawa A, Muraki Y, Hatano N and Muraki K. (2016) Diclofenac, a nonsteroidal anti-inflammatory drug, is an antagonist of human TRPM3 isoforms. Pharmacol Res Perspect 4: e00232 [PMID:27433342]

854. Suzuki M, Hirao A and Mizuno A. (2003) Microtubule-associated [corrected] protein 7 increases the membrane expression of transient receptor potential vanilloid 4 (TRPV4). J Biol Chem 278: 51448-53 [PMID:14517216]

855. Suzuki M, Ishibashi K, Ooki G, Tsuruoka S and Imai M. (2000) Electrophysiologic characteristics of the Ca-permeable channels, $\mathrm{ECaC}$ and $\mathrm{CaT}$, in the kidney. Biochem Biophys Res Commun 274: 344-9 [PMID:10913341]

856. Suzuki M, Mizuno A, Kodaira K and Imai M. (2003) Impaired pressure sensation in mice lacking TRPV4. J Biol Chem 278: 22664-8 [PMID:12692122]

857. Swanson DM, Dubin AE, Shah C, Nasser N, Chang L, Dax SL, Jetter M, Breitenbucher JG, Liu C and Mazur C et al.. (2005) Identification and biological evaluation of 4-(3-trifluoromethylpyridin2-yl)piperazine-1-carboxylic acid (5-trifluoromethylpyridin-2-yl)amide, a high affinity TRPV1 (VR1) vanilloid receptor antagonist. J Med Chem 48: 1857-72 [PMID:15771431]

858. Szallasi A, Cortright DN, Blum CA and Eid SR. (2007) The vanilloid receptor TRPV1: 10 years from channel cloning to antagonist proof-of-concept. Nat Rev Drug Discov 6: 357-72 [PMID:17464295]

859. Tabuchi K, Suzuki M, Mizuno A and Hara A. (2005) Hearing impairment in TRPV4 knockout mice. Neurosci Lett 382: 304-8 [PMID:15925108]

860. Takahashi N, Kuwaki T, Kiyonaka S, Numata T, Kozai D, Mizuno Y, Yamamoto S, Naito S, Knevels E and Carmeliet P et al.. (2011) TRPA1 underlies a sensing mechanism for O2. Nat Chem Biol 7: 701-11 [PMID:21873995]

861. Takashima Y, Daniels RL, Knowlton W, Teng J, Liman ER and McKemy DD. (2007) Diversity in the neural circuitry of cold sensing revealed by genetic axonal labeling of transient receptor potential melastatin 8 neurons. J Neurosci 27: 14147-57 [PMID:18094254]

862. Takaya J, Mio K, Shiraishi T, Kurokawa T, Otsuka S, Mori Y and Uesugi M. (2015) A Potent and Site-Selective Agonist of TRPA1. J Am Chem Soc 137: 15859-64 [PMID:26630251]

863. Takezawa R, Cheng H, Beck A, Ishikawa J, Launay P, Kubota H, Kinet JP, Fleig A, Yamada T and Penner R. (2006) A pyrazole derivative potently inhibits lymphocyte Ca2+ influx and cytokine production by facilitating transient receptor potential melastatin 4 channel activity. Mol Pharmacol 69: 1413-20 [PMID:16407466]

864. Takumida M and Anniko M. (2009) Expression of canonical transient receptor potential channel (TRPC) 1-7 in the mouse inner ear. Acta Otolaryngol 129: 1351-8 [PMID:19922081]

865. Takumida M, Ishibashi T, Hamamoto T, Hirakawa K and Anniko M. (2009) Expression of transient receptor potential channel melastin (TRPM) 1-8 and TRPA1 (ankyrin) in mouse inner ear. Acta Otolaryngol 129: 1050-60 [PMID:19065290]

866. Talavera K, Gees M, Karashima Y, Meseguer VM, Vanoirbeek JA, Damann N, Everaerts W, Benoit M, Janssens A and Vennekens R et al.. (2009) Nicotine activates the chemosensory cation channel TRPA1. Nat Neurosci 12: 1293-9 [PMID:19749751]

867. Talavera K, Yasumatsu K, Voets T, Droogmans G, Shigemura N, Ninomiya Y, Margolskee RF and Nilius B. (2005) Heat activation of TRPM5 underlies thermal sensitivity of sweet taste. Nature 438: 1022-5 [PMID:16355226]

868. Tamura S, Morikawa Y and Senba E. (2005) TRPV2, a capsaicin receptor homologue, is expressed predominantly in the neurotrophin-3-dependent subpopulation of primary sensory neurons. Neuroscience 130: 223-8 [PMID:15561438]

869. Tang J, Lin Y, Zhang Z, Tikunova S, Birnbaumer L and Zhu MX. (2001) Identification of common binding sites for calmodulin and inositol 1,4,5-trisphosphate receptors on the carboxyl termini of trp channels. J Biol Chem 276: 21303-10 [PMID:11290752] 
870. Tang Y, Tang J, Chen Z, Trost C, Flockerzi V, Li M, Ramesh V and Zhu MX. (2000) Association of mammalian trp4 and phospholipase C isozymes with a PDZ domain-containing protein, NHERF. J Biol Chem 275: 37559-64 [PMID:10980202]

871. Taylor-Clark TE, Ghatta S, Bettner W and Undem BJ. (2009) Nitrooleic acid, an endogenous product of nitrative stress, activates nociceptive sensory nerves via the direct activation of TRPA1. Mol Pharmacol 75: 820-9 [PMID:19171673]

872. Taylor-Clark TE and Undem BJ. (2010) Ozone activates airway nerves via the selective stimulation of TRPA1 ion channels. J Physiol (Lond.) 588: 423-33 [PMID:20008466]

873. Taylor-Clark TE, Undem BJ, Macglashan Jr DW, Ghatta S, Carr MJ and McAlexander MA. (2008) Prostaglandin-induced activation of nociceptive neurons via direct interaction with transient receptor potential A1 (TRPA1). Mol Pharmacol 73: 274-81 [PMID:18000030]

874. Teruyama R, Sakuraba M, Kurotaki H and Armstrong WE. (2011) Transient receptor potential channel $\mathrm{m} 4$ and $\mathrm{m} 5$ in magnocellular cells in rat supraoptic and paraventricular nuclei. $J$ Neuroendocrinol 23: 1204-13 [PMID:21848647]

875. Thiel G, Müller I and Rössler OG. (2013) Signal transduction via TRPM3 channels in pancreatic ß-cells. J Mol Endocrinol 50: R75-83 [PMID:23511953]

876. Thiel G, Rubil S, Lesch A, Guethlein LA and Rössler OG. (2017) Transient receptor potential TRPM3 channels: Pharmacology, signaling, and biological functions. Pharmacol Res 124: 92-99 [PMID:28720517]

877. Thorneloe KS, Cheung M, Bao W, Alsaid H, Lenhard S, Jian MY, Costell M, Maniscalco-Hauk K, Krawiec JA and Olzinski A et al.. (2012) An orally active TRPV4 channel blocker prevents and resolves pulmonary edema induced by heart failure. Sci Transl Med 4: 159 ra148 [PMID:23136043]

878. Thorneloe KS, Sulpizio AC, Lin Z, Figueroa DJ, Clouse AK, McCafferty GP, Chendrimada TP, Lashinger ES, Gordon E and Evans L et al.. (2008) N-((1S)-1-\{[4-((2S)-2-\{[(2,4dichlorophenyl)sulfonyl]amino $\}$-3-hydroxypropanoyl)-1-piperazinyl]carbonyl\}-3-methylbutyl)-1benzothiophene-2-carboxamide (GSK1016790A), a novel and potent transient receptor potential vanilloid 4 channel agonist induces urinary bladder contraction and hyperactivity: Part I. $J$ Pharmacol Exp Ther 326: 432-42 [PMID:18499743]

879. Tian W, Fu Y, Garcia-Elias A, Fernández-Fernández JM, Vicente R, Kramer PL, Klein RF, Hitzemann R, Orwoll ES and Wilmot B et al.. (2009) A loss-of-function nonsynonymous polymorphism in the osmoregulatory TRPV4 gene is associated with human hyponatremia. Proc Natl Acad Sci USA 106: 14034-9 [PMID:19666518]

880. Tizzano M, Gulbransen BD, Vandenbeuch A, Clapp TR, Herman JP, Sibhatu HM, Churchill ME, Silver WL, Kinnamon SC and Finger TE. (2010) Nasal chemosensory cells use bitter taste signaling to detect irritants and bacterial signals. Proc Natl Acad Sci USA 107: 3210-5 [PMID:20133764]

881. Todaka H, Taniguchi J, Satoh J, Mizuno A and Suzuki M. (2004) Warm temperature-sensitive transient receptor potential vanilloid 4 (TRPV4) plays an essential role in thermal hyperalgesia. $J$ Biol Chem 279: 35133-8 [PMID:15187078]

882. Togashi K, Hara Y, Tominaga T, Higashi T, Konishi Y, Mori Y and Tominaga M. (2006) TRPM2 activation by cyclic ADP-ribose at body temperature is involved in insulin secretion. EMBO J 25: 1804-15 [PMID:16601673]

883. Togashi K, Inada $\mathrm{H}$ and Tominaga M. (2008) Inhibition of the transient receptor potential cation channel TRPM2 by 2-aminoethoxydiphenyl borate (2-APB). Br J Pharmacol 153: 1324-30 [PMID:18204483]

884. Tominaga M, Caterina MJ, Malmberg AB, Rosen TA, Gilbert H, Skinner K, Raumann BE, Basbaum AI and Julius D. (1998) The cloned capsaicin receptor integrates multiple painproducing stimuli. Neuron 21: 531-43 [PMID:9768840]

885. Tong Q, Chu X, Cheung JY, Conrad K, Stahl R, Barber DL, Mignery G and Miller BA. (2004) Erythropoietin-modulated calcium influx through TRPC2 is mediated by phospholipase Cgamma and IP3R. Am J Physiol, Cell Physiol 287: C1667-78 [PMID:15329338]

886. Tong Q, Zhang W, Conrad K, Mostoller K, Cheung JY, Peterson BZ and Miller BA. (2006) Regulation of the transient receptor potential channel TRPM2 by the Ca2+ sensor calmodulin. $J$ Biol Chem 281: 9076-85 [PMID:16461353]

887. Trebak M, Lemonnier L, Smyth JT, Vazquez G and Putney JW. (2007) Phospholipase C-coupled receptors and activation of TRPC channels. Handb Exp Pharmacol: 593-614 [PMID:17217081]

888. Trevisan G, Materazzi S, Fusi C, Altomare A, Aldini G, Lodovici M, Patacchini R, Geppetti P and Nassini R. (2013) Novel therapeutic strategy to prevent chemotherapy-induced persistent sensory neuropathy by TRPA1 blockade. Cancer Res 73: 3120-31 [PMID:23477783]

889. Trevisani M, Siemens J, Materazzi S, Bautista DM, Nassini R, Campi B, Imamachi N, Andrè E, Patacchini R and Cottrell GS et al.. (2007) 4-Hydroxynonenal, an endogenous aldehyde, causes pain and neurogenic inflammation through activation of the irritant receptor TRPA1. Proc Natl Acad Sci USA 104: 13519-24 [PMID:17684094]

890. Trevisani M, Smart D, Gunthorpe MJ, Tognetto M, Barbieri M, Campi B, Amadesi S, Gray J, Jerman JC and Brough SJ et al.. (2002) Ethanol elicits and potentiates nociceptor responses via 
the vanilloid receptor-1. Nat Neurosci 5: 546-51 [PMID:11992116]

891. Tsavaler L, Shapero MH, Morkowski S and Laus R. (2001) Trp-p8, a novel prostate-specific gene, is up-regulated in prostate cancer and other malignancies and shares high homology with transient receptor potential calcium channel proteins. Cancer Res 61: 3760-9 [PMID:11325849]

892. Tsiokas L, Arnould T, Zhu C, Kim E, Walz G and Sukhatme VP. (1999) Specific association of the gene product of PKD2 with the TRPC1 channel. Proc Natl Acad Sci USA 96: 3934-9 [PMID:10097141]

893. Tsiokas L, Kim E, Arnould T, Sukhatme VP and Walz G. (1997) Homo- and heterodimeric interactions between the gene products of PKD1 and PKD2. Proc Natl Acad Sci USA 94: 696570 [PMID:9192675]

894. Tsutsumi M, Denda S, Ikeyama K, Goto M and Denda M. (2010) Exposure to low temperature induces elevation of intracellular calcium in cultured human keratinocytes. J Invest Dermatol 130: 1945-8 [PMID:20182444]

895. Tsuzuki Y, Sawamoto D, Sakamoto T, Kato T, Niwa Y and Awai N. (2012) Sulfonamide compounds having trpm8 antagonistic activity Patent number: WO2012124825.

896. Tsvilovskyy VV, Zholos AV, Aberle T, Philipp SE, Dietrich A, Zhu MX, Birnbaumer L, Freichel M and Flockerzi V. (2009) Deletion of TRPC4 and TRPC6 in mice impairs smooth muscle contraction and intestinal motility in vivo. Gastroenterology 137: 1415-24 [PMID:19549525]

897. Tympanidis P, Casula MA, Yiangou Y, Terenghi G, Dowd P and Anand P. (2004) Increased vanilloid receptor VR1 innervation in vulvodynia. Eur J Pain 8: 129-33 [PMID:14987622]

898. Tóth B and Csanády L. (2012) Pore collapse underlies irreversible inactivation of TRPM2 cation channel currents. Proc Natl Acad Sci USA 109: 13440-5 [PMID:22847436]

899. Tóth B and Csanády L. (2010) Identification of direct and indirect effectors of the transient receptor potential melastatin 2 (TRPM2) cation channel. J Biol Chem 285: 30091-102 [PMID:20650899]

900. Tóth B, Iordanov I and Csanády L. (2015) Ruling out pyridine dinucleotides as true TRPM2 channel activators reveals novel direct agonist ADP-ribose-2'-phosphate. J Gen Physiol 145: 41930 [PMID:25918360]

901. Tóth BI and Nilius B. (2015) Transient Receptor Potential Dysfunctions in Hereditary Diseases: TRP Channelopathies and Beyond In TRP Channels as Therapeutic Target Edited by Szallasi A: Elsevier Inc: 13-33 [ISBN: 9780124200241]

902. Uemura T, Kudoh J, Noda S, Kanba S and Shimizu N. (2005) Characterization of human and mouse TRPM2 genes: identification of a novel N-terminal truncated protein specifically expressed in human striatum. Biochem Biophys Res Commun 328: 1232-43 [PMID:15708008]

903. Uhl GR, Walther D, Behm FM and Rose JE. (2011) Menthol preference among smokers: association with TRPA1 variants. Nicotine Tob Res 13: 1311-5 [PMID:21719896]

904. Ullrich ND, Voets T, Prenen J, Vennekens R, Talavera K, Droogmans G and Nilius B. (2005) Comparison of functional properties of the Ca2+-activated cation channels TRPM4 and TRPM5 from mice. Cell Calcium 37: 267-78 [PMID:15670874]

905. Urban N, Wang L, Kwiek S, Rademann J, Kuebler WM and Schaefer M. (2016) Identification and Validation of Larixyl Acetate as a Potent TRPC6 Inhibitor. Mol Pharmacol 89: 197-213 [PMID:26500253]

906. Vaeth M and Feske S. (2018) Ion channelopathies of the immune system. Curr Opin Immunol 52: 39-50 [PMID:29635109]

907. Valenzano KJ, Grant ER, Wu G, Hachicha M, Schmid L, Tafesse L, Sun Q, Rotshteyn Y, Francis J and Limberis J et al.. (2003) N-(4-tertiarybutylphenyl)-4-(3-chloropyridin-2-yl)tetrahydropyrazine $-1(2 \mathrm{H})$-carbox-amide (BCTC), a novel, orally effective vanilloid receptor 1 antagonist with analgesic properties: I. in vitro characterization and pharmacokinetic properties. J Pharmacol Exp Ther 306: 377-86 [PMID:12721338]

908. Van Abel M, Hoenderop JG, Dardenne O, St Arnaud R, Van Os CH, Van Leeuwen HJ and Bindels RJ. (2002) 1,25-dihydroxyvitamin D(3)-independent stimulatory effect of estrogen on the expression of ECaC1 in the kidney. J Am Soc Nephrol 13: 2102-9 [PMID:12138142]

909. van Abel M, Hoenderop JG, van der Kemp AW, Friedlaender MM, van Leeuwen JP and Bindels RJ. (2005) Coordinated control of renal $\mathrm{Ca}(2+)$ transport proteins by parathyroid hormone. Kidney Int 68: 1708-21 [PMID:16164647]

910. Van Cromphaut SJ, Dewerchin M, Hoenderop JG, Stockmans I, Van Herck E, Kato S, Bindels RJ, Collen D, Carmeliet P and Bouillon R et al.. (2001) Duodenal calcium absorption in vitamin D receptor-knockout mice: functional and molecular aspects. Proc Natl Acad Sci USA 98: 13324-9 [PMID:11687634]

911. van de Graaf SF, Chang Q, Mensenkamp AR, Hoenderop JG and Bindels RJ. (2006) Direct interaction with Rab11a targets the epithelial Ca2+ channels TRPV5 and TRPV6 to the plasma membrane. Mol Cell Biol 26: 303-12 [PMID:16354700]

912. van de Graaf SF, Hoenderop JG, Gkika D, Lamers D, Prenen J, Rescher U, Gerke V, Staub O, Nilius B and Bindels RJ. (2003) Functional expression of the epithelial $\mathrm{Ca}(2+)$ channels (TRPV5 and TRPV6) requires association of the S100A10-annexin 2 complex. EMBOJ 22: 1478-87 
[PMID:12660155]

913. van de Graaf SF, Hoenderop JG, van der Kemp AW, Gisler SM and Bindels RJ. (2006) Interaction of the epithelial Ca2 + channels TRPV5 and TRPV6 with the intestine- and kidney-enriched PDZ protein NHERF4. Pflugers Arch 452: 407-17 [PMID:16565876]

914. van de Graaf SF, van der Kemp AW, van den Berg D, van Oorschot M, Hoenderop JG and Bindels RJ. (2006) Identification of BSPRY as a novel auxiliary protein inhibiting TRPV5 activity. $\mathrm{J} \mathrm{Am}$ Soc Nephrol 17: 26-30 [PMID:16380433]

915. van der Eerden BC, Hoenderop JG, de Vries TJ, Schoenmaker T, Buurman CJ, Uitterlinden AG, Pols HA, Bindels RJ and van Leeuwen JP. (2005) The epithelial Ca2 + channel TRPV5 is essential for proper osteoclastic bone resorption. Proc Natl Acad Sci USA 102: 17507-12 [PMID:16291808]

916. van Genderen MM, Bijveld MM, Claassen YB, Florijn RJ, Pearring JN, Meire FM, McCall MA, Riemslag FC, Gregg RG and Bergen AA et al.. (2009) Mutations in TRPM1 are a common cause of complete congenital stationary night blindness. Am J Hum Genet 85: 730-6 [PMID:19896109]

917. Vandewauw I, De Clercq K, Mulier M, Held K, Pinto S, Van Ranst N, Segal A, Voet T, Vennekens $\mathrm{R}$ and Zimmermann $\mathrm{K}$ et al.. (2018) A TRP channel trio mediates acute noxious heat sensing. Nature 555: 662-666 [PMID:29539642]

918. Vannier B, Peyton M, Boulay G, Brown D, Qin N, Jiang M, Zhu X and Birnbaumer L. (1999) Mouse trp2, the homologue of the human trpc2 pseudogene, encodes mTrp2, a store depletionactivated capacitative Ca2 + entry channel. Proc Natl Acad Sci USA 96: 2060-4 [PMID:10051594]

919. Veldhuis NA, Poole DP, Grace M, McIntyre P and Bunnett NW. (2015) The G protein-coupled receptor-transient receptor potential channel axis: molecular insights for targeting disorders of sensation and inflammation. Pharmacol Rev 67: 36-73 [PMID:25361914]

920. Veldhuisen B, Spruit L, Dauwerse HG, Breuning MH and Peters DJ. (1999) Genes homologous to the autosomal dominant polycystic kidney disease genes (PKD1 and PKD2). Eur J Hum Genet 7: 860-72 [PMID:10602361]

921. Venkatachalam K, Hofmann T and Montell C. (2006) Lysosomal localization of TRPML3 depends on TRPML2 and the mucolipidosis-associated protein TRPML1. J Biol Chem 281: 17517-27 [PMID:16606612]

922. Venkatachalam K and Montell C. (2007) TRP channels. Annu Rev Biochem 76: 387-417 [PMID:17579562]

923. Vennekens R, Hoenderop JG, Prenen J, Stuiver M, Willems PH, Droogmans G, Nilius B and Bindels RJ. (2000) Permeation and gating properties of the novel epithelial $\mathrm{Ca}(2+)$ channel. $J$ Biol Chem 275: 3963-9 [PMID:10660551]

924. Vennekens R and Nilius B. (2007) Insights into TRPM4 function, regulation and physiological role. Handb Exp Pharmacol: 269-85 [PMID:17217063]

925. Vennekens R, Olausson J, Meissner M, Bloch W, Mathar I, Philipp SE, Schmitz F, Weissgerber P, Nilius B and Flockerzi V et al.. (2007) Increased IgE-dependent mast cell activation and anaphylactic responses in mice lacking the calcium-activated nonselective cation channel TRPM4. Nat Immunol 8: 312-20 [PMID:17293867]

926. Vennekens R, Owsianik G and Nilius B. (2008) Vanilloid transient receptor potential cation channels: an overview. Curr Pharm Des 14: 18-31 [PMID:18220815]

927. Vennekens R, Prenen J, Hoenderop JG, Bindels RJ, Droogmans G and Nilius B. (2001) Modulation of the epithelial Ca2+ channel ECaC by extracellular pH. Pflugers Arch 442: 237-42 [PMID:11417220]

928. Venugopal B, Mesires NT, Kennedy JC, Curcio-Morelli C, Laplante JM, Dice JF and Slaugenhaupt SA. (2009) Chaperone-mediated autophagy is defective in mucolipidosis type IV.J Cell Physiol 219: 344-53 [PMID:19117012]

929. Vergarajauregui S, Connelly PS, Daniels MP and Puertollano R. (2008) Autophagic dysfunction in mucolipidosis type IV patients. Hum Mol Genet 17: 2723-37 [PMID:18550655]

930. Vergarajauregui S, Martina JA and Puertollano R. (2009) Identification of the penta-EF-hand protein ALG-2 as a Ca2+-dependent interactor of mucolipin-1. J Biol Chem 284: 36357-66 [PMID:19864416]

931. Vergarajauregui S, Martina JA and Puertollano R. (2011) LAPTMs regulate lysosomal function and interact with mucolipin 1: new clues for understanding mucolipidosis type IV. J Cell Sci 124: 459-68 [PMID:21224396]

932. Vilceanu D and Stucky CL. (2010) TRPA1 mediates mechanical currents in the plasma membrane of mouse sensory neurons. PLoS ONE 5: e12177 [PMID:20808441]

933. Vincent F, Acevedo A, Nguyen MT, Dourado M, DeFalco J, Gustafson A, Spiro P, Emerling DE, Kelly MG and Duncton MA. (2009) Identification and characterization of novel TRPV4 modulators. Biochem Biophys Res Commun 389: 490-4 [PMID:19737537]

934. Viribay M, Hayashi T, Tellería D, Mochizuki T, Reynolds DM, Alonso R, Lens XM, Moreno F, Harris PC and Somlo S et al.. (1997) Novel stop and frameshifting mutations in the autosomal dominant polycystic kidney disease 2 (PKD2) gene. Hum Genet 101: 229-34 [PMID:9402976] 
935. Viswanath V, Story GM, Peier AM, Petrus MJ, Lee VM, Hwang SW, Patapoutian A and Jegla T. (2003) Opposite thermosensor in fruitfly and mouse. Nature 423: 822-3 [PMID:12815418]

936. Voets T, Droogmans G, Wissenbach U, Janssens A, Flockerzi V and Nilius B. (2004) The principle of temperature-dependent gating in cold- and heat-sensitive TRP channels. Nature 430: 748-54 [PMID:15306801]

937. Voets T, Janssens A, Droogmans G and Nilius B. (2004) Outer pore architecture of a Ca2+selective TRP channel. J Biol Chem 279: 15223-30 [PMID:14736889]

938. Voets T, Janssens A, Prenen J, Droogmans G and Nilius B. (2003) Mg2+-dependent gating and strong inward rectification of the cation channel TRPV6. J Gen Physiol 121: 245-60 [PMID:12601087]

939. Voets T and Nilius B. (2007) Modulation of TRPs by PIPs. J Physiol (Lond.) 582: 939-44 [PMID:17395625]

940. Voets T, Nilius B, Hoefs S, van der Kemp AW, Droogmans G, Bindels RJ and Hoenderop JG. (2004) TRPM6 forms the Mg2+ influx channel involved in intestinal and renal Mg2+ absorption. J Biol Chem 279: 19-25 [PMID:14576148]

941. Voets T, Owsianik G and Nilius B. (2007) TRPM8. Handb Exp Pharmacol: 329-44 [PMID:17217067]

942. Voets T, Prenen J, Fleig A, Vennekens R, Watanabe H, Hoenderop JG, Bindels RJ, Droogmans G, Penner R and Nilius B. (2001) CaT1 and the calcium release-activated calcium channel manifest distinct pore properties. J Biol Chem 276: 47767-70 [PMID:11687570]

943. Voets T, Prenen J, Vriens J, Watanabe H, Janssens A, Wissenbach U, Bödding M, Droogmans G and Nilius B. (2002) Molecular determinants of permeation through the cation channel TRPV4. J Biol Chem 277: 33704-10 [PMID:12093812]

944. Vogt-Eisele AK, Weber K, Sherkheli MA, Vielhaber G, Panten J, Gisselmann G and Hatt H. (2007) Monoterpenoid agonists of TRPV3. Br J Pharmacol 151: 530-40 [PMID:17420775]

945. Vriens J, Appendino G and Nilius B. (2009) Pharmacology of vanilloid transient receptor potential cation channels. Mol Pharmacol 75: 1262-79 [PMID:19297520]

946. Vriens J, Held K, Janssens A, Tóth BI, Kerselaers S, Nilius B, Vennekens R and Voets T. (2014) Opening of an alternative ion permeation pathway in a nociceptor TRP channel. Nat Chem Biol 10: 188-95 [PMID:24390427]

947. Vriens J, Owsianik G, Hofmann T, Philipp SE, Stab J, Chen X, Benoit M, Xue F, Janssens A and Kerselaers $S$ et al.. (2011) TRPM3 is a nociceptor channel involved in the detection of noxious heat. Neuron 70: 482-94 [PMID:21555074]

948. Vriens J and Voets T. (2018) Sensing the heat with TRPM3. Pflugers Arch 470: 799-807 [PMID:29305649]

949. Wagner SA, Beli P, Weinert BT, Nielsen ML, Cox J, Mann M and Choudhary C. (2011) A proteome-wide, quantitative survey of in vivo ubiquitylation sites reveals widespread regulatory roles. Mol Cell Proteomics 10: M111.013284 [PMID:21890473]

950. Wagner TF, Loch S, Lambert S, Straub I, Mannebach S, Mathar I, Düfer M, Lis A, Flockerzi V and Philipp SE et al.. (2008) Transient receptor potential M3 channels are ionotropic steroid receptors in pancreatic beta cells. Nat Cell Biol 10: 1421-30 [PMID:18978782]

951. Wahl P, Foged C, Tullin S and Thomsen C. (2001) Iodo-resiniferatoxin, a new potent vanilloid receptor antagonist. Mol Pharmacol 59: 9-15 [PMID:11125018]

952. Walder RY, Landau D, Meyer P, Shalev H, Tsolia M, Borochowitz Z, Boettger MB, Beck GE, Englehardt RK and Carmi R et al.. (2002) Mutation of TRPM6 causes familial hypomagnesemia with secondary hypocalcemia. Nat Genet 31: 171-4 [PMID:12032570]

953. Walker RL, Koh SD, Sergeant GP, Sanders KM and Horowitz B. (2002) TRPC4 currents have properties similar to the pacemaker current in interstitial cells of Cajal. Am J Physiol, Cell Physiol 283: C1637-45 [PMID:12388058]

954. Wang HL, Katon J, Balan C, Bannon AW, Bernard C, Doherty EM, Dominguez C, Gavva NR, Gore $\mathrm{V}$ and $\mathrm{Ma} \mathrm{V}$ et al.. (2007) Novel vanilloid receptor-1 antagonists: 3. The identification of a second-generation clinical candidate with improved physicochemical and pharmacokinetic properties. J Med Chem 50: 3528-39 [PMID:17585751]

955. Wang L, Fu TM, Zhou Y, Xia S, Greka A and Wu H. (2018) Structures and gating mechanism of human TRPM2. Science 362 [PMID:30467180]

956. Wang W, O'Connell B, Dykeman R, Sakai T, Delporte C, Swaim W, Zhu X, Birnbaumer L and Ambudkar IS. (1999) Cloning of Trp1beta isoform from rat brain: immunodetection and localization of the endogenous Trp1 protein. Am J Physiol 276: C969-79 [PMID:10199829]

957. Wang X, Zhang X, Dong XP, Samie M, Li X, Cheng X, Goschka A, Shen D, Zhou Y and Harlow J et al.. (2012) TPC proteins are phosphoinositide- activated sodium-selective ion channels in endosomes and lysosomes. Cell 151: 372-83 [PMID:23063126]

958. Wang Y, Bu J, Shen H, Li H, Wang Z and Chen G. (2017) Targeting Transient Receptor Potential Canonical Channels for Diseases of the Nervous System. Curr Drug Targets 18: 1460-1465 [PMID:26648074]

959. Wang Y, Fu X, Gaiser S, Köttgen M, Kramer-Zucker A, Walz G and Wegierski T. (2007) OS-9 
regulates the transit and polyubiquitination of TRPV4 in the endoplasmic reticulum. J Biol Chem 282: 36561-70 [PMID:17932042]

960. Wang Y, Szabo T, Welter JD, Toth A, Tran R, Lee J, Kang SU, Suh YG, Blumberg PM and Lee J. (2002) High affinity antagonists of the vanilloid receptor. Mol Pharmacol 62: 947-56 [PMID:12237342]

961. Wang YY, Chang RB, Allgood SD, Silver WL and Liman ER. (2011) A TRPA1-dependent mechanism for the pungent sensation of weak acids. J Gen Physiol 137: 493-505 [PMID:21576376]

962. Wang YY, Chang RB and Liman ER. (2010) TRPA1 is a component of the nociceptive response to CO2. J Neurosci 30: 12958-63 [PMID:20881114]

963. Washburn DG, Holt DA, Dodson J, McAtee JJ, Terrell LR, Barton L, Manns S, Waszkiewicz A, Pritchard C and Gillie DJ et al.. (2013) The discovery of potent blockers of the canonical transient receptor channels, TRPC3 and TRPC6, based on an anilino-thiazole pharmacophore. Bioorg Med Chem Lett 23: 4979-84 [PMID:23886683]

964. Watanabe H, Davis JB, Smart D, Jerman JC, Smith GD, Hayes P, Vriens J, Cairns W, Wissenbach U and Prenen J et al.. (2002) Activation of TRPV4 channels (hVRL-2/mTRP12) by phorbol derivatives. $J$ Biol Chem 277: 13569-77 [PMID:11827975]

965. Watanabe H, Vriens J, Prenen J, Droogmans G, Voets T and Nilius B. (2003) Anandamide and arachidonic acid use epoxyeicosatrienoic acids to activate TRPV4 channels. Nature 424: 434-8 [PMID:12879072]

966. Watanabe H, Vriens J, Suh SH, Benham CD, Droogmans G and Nilius B. (2002) Heat-evoked activation of TRPV4 channels in a HEK293 cell expression system and in native mouse aorta endothelial cells. J Biol Chem 277: 47044-51 [PMID:12354759]

967. Weber K, Erben RG, Rump A and Adamski J. (2001) Gene structure and regulation of the murine epithelial calcium channels ECaC1 and 2. Biochem Biophys Res Commun 289: 1287-94 [PMID:11741335]

968. Weber KS, Hildner K, Murphy KM and Allen PM. (2010) Trpm4 differentially regulates Th1 and Th2 function by altering calcium signaling and NFAT localization. J Immunol 185: 2836-46 [PMID:20656926]

969. Wehage E, Eisfeld J, Heiner I, Jüngling E, Zitt C and Lückhoff A. (2002) Activation of the cation channel long transient receptor potential channel 2 (LTRPC2) by hydrogen peroxide. A splice variant reveals a mode of activation independent of ADP-ribose. J Biol Chem 277: 23150-6 [PMID:11960981]

970. Wehrhahn J, Kraft R, Harteneck C and Hauschildt S. (2010) Transient receptor potential melastatin 2 is required for lipopolysaccharide-induced cytokine production in human monocytes. J Immunol 184: 2386-93 [PMID:20107186]

971. Wei C, Wang X, Chen M, Ouyang K, Song LS and Cheng H. (2009) Calcium flickers steer cell migration. Nature 457: 901-5 [PMID:19118385]

972. Wei H, Hämäläinen MM, Saarnilehto M, Koivisto A and Pertovaara A. (2009) Attenuation of mechanical hypersensitivity by an antagonist of the TRPA1 ion channel in diabetic animals. Anesthesiology 111: 147-54 [PMID:19512877]

973. Wei ZL, Nguyen MT, O'Mahony DJ, Acevedo A, Zipfel S, Zhang Q, Liu L, Dourado M, Chi C and Yip V et al.. (2015) Identification of orally-bioavailable antagonists of the TRPV4 ion-channel. Bioorg Med Chem Lett 25: 4011-5 [PMID:26235950]

974. Weissgerber P, Kriebs U, Tsvilovskyy V, Olausson J, Kretz O, Stoerger C, Mannebach S, Wissenbach U, Vennekens R and Middendorff R et al.. (2012) Excision of Trpv6 gene leads to severe defects in epididymal Ca2+ absorption and male fertility much like single D541A pore mutation. J Biol Chem 287: 17930-41 [PMID:22427671]

975. Weissgerber P, Kriebs U, Tsvilovskyy V, Olausson J, Kretz O, Stoerger C, Vennekens R, Wissenbach U, Middendorff R and Flockerzi V et al.. (2011) Male fertility depends on $\mathrm{Ca}^{2}+$ absorption by TRPV6 in epididymal epithelia. Sci Signal 4: ra27 [PMID:21540454]

976. Weissmann N, Sydykov A, Kalwa H, Storch U, Fuchs B, Mederos y Schnitzler M, Brandes RP, Grimminger F, Meissner M and Freichel M et al.. (2012) Activation of TRPC6 channels is essential for lung ischaemia-reperfusion induced oedema in mice. Nat Commun 3: 649 [PMID:22337127]

977. Wescott SA, Rauthan M and Xu XZ. (2013) When a TRP goes bad: transient receptor potential channels in addiction. Life Sci 92: 410-4 [PMID:22820171]

978. Willette RN, Bao W, Nerurkar S, Yue TL, Doe CP, Stankus G, Turner GH, Ju H, Thomas H and Fishman CE et al.. (2008) Systemic activation of the transient receptor potential vanilloid subtype 4 channel causes endothelial failure and circulatory collapse: Part 2.J Pharmacol Exp Ther 326: 443-52 [PMID:18499744]

979. Wilson SR, Gerhold KA, Bifolck-Fisher A, Liu Q, Patel KN, Dong X and Bautista DM. (2011) TRPA1 is required for histamine-independent, Mas-related G protein-coupled receptor-mediated itch. Nat Neurosci 14: 595-602 [PMID:21460831]

980. Wilson SR, Nelson AM, Batia L, Morita T, Estandian D, Owens DM, Lumpkin EA and Bautista 
DM. (2013) The ion channel TRPA1 is required for chronic itch. J Neurosci 33: 9283-94 [PMID:23719797]

981. Winn MP, Conlon PJ, Lynn KL, Farrington MK, Creazzo T, Hawkins AF, Daskalakis N, Kwan SY, Ebersviller S and Burchette JL et al.. (2005) A mutation in the TRPC6 cation channel causes familial focal segmental glomerulosclerosis. Science 308: 1801-4 [PMID:15879175]

982. Wissenbach U and Niemeyer BA. (2007) TRPV6. Handb Exp Pharmacol: 221-34 [PMID:17217060]

983. Wissenbach U, Niemeyer BA, Fixemer T, Schneidewind A, Trost C, Cavalie A, Reus K, Meese E, Bonkhoff $\mathrm{H}$ and Flockerzi V. (2001) Expression of CaT-like, a novel calcium-selective channel, correlates with the malignancy of prostate cancer. J Biol Chem 276: 19461-8 [PMID:11278579]

984. Wistow G, Bernstein SL, Ray S, Wyatt MK, Behal A, Touchman JW, Bouffard G, Smith D and Peterson K. (2002) Expressed sequence tag analysis of adult human iris for the NEIBank Project: steroid-response factors and similarities with retinal pigment epithelium. Mol Vis 8: 185-95 [PMID:12107412]

985. Wistow G, Bernstein SL, Wyatt MK, Fariss RN, Behal A, Touchman JW, Bouffard G, Smith D and Peterson K. (2002) Expressed sequence tag analysis of human RPE/choroid for the NEIBank Project: over 6000 non-redundant transcripts, novel genes and splice variants. Mol Vis 8: 205-20 [PMID:12107410]

986. Witzgall R. (2007) TRPP2 channel regulation. Handb Exp Pharmacol: 363-75 [PMID:17217069]

987. Wodicka LM, Ciceri P, Davis MI, Hunt JP, Floyd M, Salerno S, Hua XH, Ford JM, Armstrong RC and Zarrinkar PP et al.. (2010) Activation state-dependent binding of small molecule kinase inhibitors: structural insights from biochemistry. Chem Biol 17: 1241-9 [PMID:21095574]

988. Wong CO, Huang Y and Yao X. (2010) Genistein potentiates activity of the cation channel TRPC5 independently of tyrosine kinases. Br J Pharmacol 159: 1486-96 [PMID:20233211]

989. Woo SK, Kwon MS, Ivanov A, Gerzanich V and Simard JM. (2013) The sulfonylurea receptor 1 (Sur1)-transient receptor potential melastatin 4 (Trpm4) channel. J Biol Chem 288: 3655-67 [PMID:23255597]

990. Woudenberg-Vrenken TE, Sukinta A, van der Kemp AW, Bindels RJ and Hoenderop JG. (2011) Transient receptor potential melastatin 6 knockout mice are lethal whereas heterozygous deletion results in mild hypomagnesemia. Nephron Physiol 117: p11-9 [PMID:20814221]

991. Wu G, D'Agati V, Cai Y, Markowitz G, Park JH, Reynolds DM, Maeda Y, Le TC, Hou Jr H and Kucherlapati R et al.. (1998) Somatic inactivation of Pkd2 results in polycystic kidney disease. Cell 93: 177-88 [PMID:9568711]

992. Wu G, Hayashi T, Park JH, Dixit M, Reynolds DM, Li L, Maeda Y, Cai Y, Coca-Prados M and Somlo S. (1998) Identification of PKD2L, a human PKD2-related gene: tissue-specific expression and mapping to chromosome 10q25. Genomics 54: 564-8 [PMID:9878261]

993. Wu G, Markowitz GS, Li L, D'Agati VD, Factor SM, Geng L, Tibara S, Tuchman J, Cai Y and Park $\mathrm{JH}$ et al.. (2000) Cardiac defects and renal failure in mice with targeted mutations in Pkd2. Nat Genet 24: 75-8 [PMID:10615132]

994. Wu G, Mochizuki T, Le TC, Cai Y, Hayashi T, Reynolds DM and Somlo S. (1997) Molecular cloning, cDNA sequence analysis, and chromosomal localization of mouse Pkd2. Genomics 45: 220-3 [PMID:9339380]

995. Wu G, Tian X, Nishimura S, Markowitz GS, D'Agati V, Park JH, Yao L, Li L, Geng L and Zhao H et al.. (2002) Trans-heterozygous Pkd1 and Pkd2 mutations modify expression of polycystic kidney disease. Hum Mol Genet 11: 1845-54 [PMID:12140187]

996. Wu L, Gao X, Brown RC, Heller S and O'Neil RG. (2007) Dual role of the TRPV4 channel as a sensor of flow and osmolality in renal epithelial cells. Am J Physiol Renal Physiol 293: F1699713 [PMID:17699550]

997. Wu LJ, Sweet TB and Clapham DE. (2010) International Union of Basic and Clinical Pharmacology. LXXVI. Current progress in the mammalian TRP ion channel family. Pharmacol Rev 62: 381-404 [PMID:20716668]

998. Wu X, Eder P, Chang B and Molkentin JD. (2010) TRPC channels are necessary mediators of pathologic cardiac hypertrophy. Proc Natl Acad Sci USA 107: 7000-5 [PMID:20351294]

999. Xenophontos S, Constantinides R, Hayashi T, Mochizuki T, Somlo S, Pierides A and Deltas CC. (1997) A translation frameshift mutation induced by a cytosine insertion in the polycystic kidney disease 2 gene (PDK2). Hum Mol Genet 6: 949-52 [PMID:9175744]

000. Xiao B, Dubin AE, Bursulaya B, Viswanath V, Jegla TJ and Patapoutian A. (2008) Identification of transmembrane domain 5 as a critical molecular determinant of menthol sensitivity in mammalian TRPA1 channels. J Neurosci 28: 9640-51 [PMID:18815250]

001. Xiao R, Tang J, Wang C, Colton CK, Tian J and Zhu MX. (2008) Calcium plays a central role in the sensitization of TRPV3 channel to repetitive stimulations. J Biol Chem 283: 6162-74 [PMID:18178557]

002. Xu C, Macciardi F, Li PP, Yoon IS, Cooke RG, Hughes B, Parikh SV, McIntyre RS, Kennedy JL and Warsh JJ. (2006) Association of the putative susceptibility gene, transient receptor potential protein melastatin type 2, with bipolar disorder. Am J Med Genet B Neuropsychiatr Genet 141B: 
36-43 [PMID:16252251]

003. Xu F, Satoh E and Iijima T. (2003) Protein kinase C-mediated Ca2+ entry in HEK 293 cells transiently expressing human TRPV4. Br J Pharmacol 140: 413-21 [PMID:12970074]

004. Xu H, Blair NT and Clapham DE. (2005) Camphor activates and strongly desensitizes the transient receptor potential vanilloid subtype 1 channel in a vanilloid-independent mechanism. $J$ Neurosci 25: 8924-37 [PMID:16192383]

005. Xu H, Delling M, Jun JC and Clapham DE. (2006) Oregano, thyme and clove-derived flavors and skin sensitizers activate specific TRP channels. Nat Neurosci 9: 628-35 [PMID:16617338]

006. Xu H, Delling M, Li L, Dong X and Clapham DE. (2007) Activating mutation in a mucolipin transient receptor potential channel leads to melanocyte loss in varitint-waddler mice. Proc Natl Acad Sci USA 104: 18321-6 [PMID:17989217]

007. Xu H, Ramsey IS, Kotecha SA, Moran MM, Chong JA, Lawson D, Ge P, Lilly J, Silos-Santiago I and Xie Y et al.. (2002) TRPV3 is a calcium-permeable temperature-sensitive cation channel. Nature 418: 181-6 [PMID:12077604]

008. Xu H and Ren D. (2015) Lysosomal physiology. Annu Rev Physiol 77: 57-80 [PMID:25668017]

009. Xu H, Zhao H, Tian W, Yoshida K, Roullet JB and Cohen DM. (2003) Regulation of a transient receptor potential (TRP) channel by tyrosine phosphorylation. SRC family kinase-dependent tyrosine phosphorylation of TRPV4 on TYR-253 mediates its response to hypotonic stress. J Biol Chem 278: 11520-7 [PMID:12538589]

010. Xu SZ, Zeng F, Boulay G, Grimm C, Harteneck C and Beech DJ. (2005) Block of TRPC5 channels by 2-aminoethoxydiphenyl borate: a differential, extracellular and voltage-dependent effect. $\mathrm{Br} J$ Pharmacol 145: 405-14 [PMID:15806115]

011. Xu X, Lozinskaya I, Costell M, Lin Z, Ball JA, Bernard R, Behm DJ, Marino JP and Schnackenberg CG. (2013) Characterization of Small Molecule TRPC3 and TRPC6 agonist and Antagonists Biophys J 104: 454a

012. Xu XZ, Moebius F, Gill DL and Montell C. (2001) Regulation of melastatin, a TRP-related protein, through interaction with a cytoplasmic isoform. Proc Natl Acad Sci USA 98: 10692-7 [PMID:11535825]

013. Xue T, Do MT, Riccio A, Jiang Z, Hsieh J, Wang HC, Merbs SL, Welsbie DS, Yoshioka T and Weissgerber $\mathrm{P}$ et al.. (2011) Melanopsin signalling in mammalian iris and retina. Nature 479: 67-73 [PMID:22051675]

014. Yamada T, Ueda T, Shibata Y, Ikegami Y, Saito M, Ishida Y, Ugawa S, Kohri K and Shimada S. (2010) TRPV2 activation induces apoptotic cell death in human T24 bladder cancer cells: a potential therapeutic target for bladder cancer. Urology 76: 509.e1-7 [PMID:20546877]

015. Yamaguchi H, Matsushita M, Nairn AC and Kuriyan J. (2001) Crystal structure of the atypical protein kinase domain of a TRP channel with phosphotransferase activity. Mol Cell 7: 1047-57 [PMID:11389851]

016. Yamaguchi S, Jha A, Li Q, Soyombo AA, Dickinson GD, Churamani D, Brailoiu E, Patel S and Muallem S. (2011) Transient receptor potential mucolipin 1 (TRPML1) and two-pore channels are functionally independent organellar ion channels. J Biol Chem 286: 22934-42 [PMID:21540176]

017. Yamamoto S, Shimizu S, Kiyonaka S, Takahashi N, Wajima T, Hara Y, Negoro T, Hiroi T, Kiuchi Y and Okada T et al.. (2008) TRPM2-mediated Ca2+influx induces chemokine production in monocytes that aggravates inflammatory neutrophil infiltration. Nat Med 14: 738-47 [PMID:18542050]

018. Yamamoto S, Takahashi N and Mori Y. (2010) Chemical physiology of oxidative stress-activated TRPM2 and TRPC5 channels. Prog Biophys Mol Biol 103: 18-27 [PMID:20553742]

019. Yamashiro K, Sasano T, Tojo K, Namekata I, Kurokawa J, Sawada N, Suganami T, Kamei Y, Tanaka H and Tajima N et al.. (2010) Role of transient receptor potential vanilloid 2 in LPSinduced cytokine production in macrophages. Biochem Biophys Res Commun 398: 284-9 [PMID:20599720]

020. Yang J, Li Y, Zuo X, Zhen Y, Yu Y and Gao L. (2008) Transient receptor potential ankyrin-1 participates in visceral hyperalgesia following experimental colitis. Neurosci Lett 440: $237-41$ [PMID:18583045]

021. Yang KT, Chang WL, Yang PC, Chien CL, Lai MS, Su MJ and Wu ML. (2006) Activation of the transient receptor potential M2 channel and poly(ADP-ribose) polymerase is involved in oxidative stress-induced cardiomyocyte death. Cell Death Differ 13: 1815-26 [PMID:16294211]

022. Yang W, Manna PT, Zou J, Luo J, Beech DJ, Sivaprasadarao A and Jiang LH. (2011) Zinc inactivates melastatin transient receptor potential 2 channels via the outer pore. J Biol Chem 286: 23789-98 [PMID:21602277]

023. Yang W, Zou J, Xia R, Vaal ML, Seymour VA, Luo J, Beech DJ and Jiang LH. (2010) Statedependent inhibition of TRPM2 channel by acidic pH. J Biol Chem 285: 30411-8 [PMID:20660597]

024. Yao X and Garland CJ. (2005) Recent developments in vascular endothelial cell transient receptor potential channels. Circ Res 97: 853-63 [PMID:16254217] 
025. Yap KL, Kim J, Truong K, Sherman M, Yuan T and Ikura M. (2000) Calmodulin target database. J Struct Funct Genomics 1: 8-14 [PMID:12836676]

026. Ye L, Kleiner S, Wu J, Sah R, Gupta RK, Banks AS, Cohen P, Khandekar MJ, Boström P and Mepani RJ et al.. (2012) TRPV4 is a regulator of adipose oxidative metabolism, inflammation, and energy homeostasis. Cell 151: 96-110 [PMID:23021218]

027. Yeh BI, Kim YK, Jabbar W and Huang CL. (2005) Conformational changes of pore helix coupled to gating of TRPV5 by protons. EMBO J 24: 3224-34 [PMID:16121193]

028. Yeh BI, Sun TJ, Lee JZ, Chen HH and Huang CL. (2003) Mechanism and molecular determinant for regulation of rabbit transient receptor potential type 5 (TRPV5) channel by extracellular $\mathrm{pH}$. J Biol Chem 278: 51044-52 [PMID:14525991]

029. Yiangou Y, Facer P, Dyer NH, Chan CL, Knowles C, Williams NS and Anand P. (2001) Vanilloid receptor 1 immunoreactivity in inflamed human bowel. Lancet 357: 1338-9 [PMID:11343743]

030. Yildirim E, Dietrich A and Birnbaumer L. (2003) The mouse C-type transient receptor potential 2 (TRPC2) channel: alternative splicing and calmodulin binding to its $\mathrm{N}$ terminus. Proc Natl Acad Sci USA 100: 2220-5 [PMID:12601176]

031. Yin Y, Wu M, Zubcevic L, Borschel WF, Lander GC and Lee SY. (2018) Structure of the cold- and menthol-sensing ion channel TRPM8. Science 359: 237-241 [PMID:29217583]

032. Yoon IS, Li PP, Siu KP, Kennedy JL, Macciardi F, Cooke RG, Parikh SV and Warsh JJ. (2001) Altered TRPC7 gene expression in bipolar-I disorder. Biol Psychiatry 50: 620-6 [PMID:11690598]

033. Yoshida T, Inoue R, Morii T, Takahashi N, Yamamoto S, Hara Y, Tominaga M, Shimizu S, Sato Y and Mori Y. (2006) Nitric oxide activates TRP channels by cysteine S-nitrosylation. Nat Chem Biol 2: 596-607 [PMID:16998480]

034. Yu CR. (2015) TRICK or TRP? What Trpc2(-/-) mice tell us about vomeronasal organ mediated innate behaviors. Front Neurosci 9: 221 [PMID:26157356]

035. Yu L, Jin W, Wang JX, Zhang X, Chen MM, Zhu ZH, Lee H, Lee M and Zhang YP. (2010) Characterization of TRPC2, an essential genetic component of VNS chemoreception, provides insights into the evolution of pheromonal olfaction in secondary-adapted marine mammals. $\mathrm{Mol}$ Biol Evol 27: 1467-77 [PMID:20142439]

036. Yu W, Hill WG, Apodaca G and Zeidel ML. (2011) Expression and distribution of transient receptor potential (TRP) channels in bladder epithelium. Am J Physiol Renal Physiol 300: F49-59 [PMID:20943764]

037. Yuan JP, Kim MS, Zeng W, Shin DM, Huang G, Worley PF and Muallem S. (2009) TRPC channels as STIM1-regulated SOCs. Channels (Austin) 3: 221-5 [PMID:19574740]

038. Yuan JP, Kiselyov K, Shin DM, Chen J, Shcheynikov N, Kang SH, Dehoff MH, Schwarz MK, Seeburg PH and Muallem S et al.. (2003) Homer binds TRPC family channels and is required for gating of TRPC1 by IP3 receptors. Cell 114: 777-89 [PMID:14505576]

039. Yuan JP, Zeng W, Dorwart MR, Choi YJ, Worley PF and Muallem S. (2009) SOAR and the polybasic STIM1 domains gate and regulate Orai channels. Nat Cell Biol 11: 337-43 [PMID:19182790]

040. Yuan JP, Zeng W, Huang GN, Worley PF and Muallem S. (2007) STIM1 heteromultimerizes TRPC channels to determine their function as store-operated channels. Nat Cell Biol 9: 636-45 [PMID:17486119]

041. Yue L, Peng JB, Hediger MA and Clapham DE. (2001) CaT1 manifests the pore properties of the calcium-release-activated calcium channel. Nature 410: 705-9 [PMID:11287959]

042. Zagranichnaya TK, Wu X and Villereal ML. (2005) Endogenous TRPC1, TRPC3, and TRPC7 proteins combine to form native store-operated channels in HEK-293 cells. J Biol Chem 280: 29559-69 [PMID:15972814]

043. Zaika O, Mamenko M, Berrout J, Boukelmoune N, O'Neil RG and Pochynyuk O. (2013) TRPV4 dysfunction promotes renal cystogenesis in autosomal recessive polycystic kidney disease. J Am Soc Nephrol 24: 604-16 [PMID:23411787]

044. Zakharian E, Thyagarajan B, French RJ, Pavlov E and Rohacs T. (2009) Inorganic polyphosphate modulates TRPM8 channels. PLoS ONE 4: e5404 [PMID:19404398]

045. Zanou N, Iwata Y, Schakman O, Lebacq J, Wakabayashi S and Gailly P. (2009) Essential role of TRPV2 ion channel in the sensitivity of dystrophic muscle to eccentric contractions. FEBS Lett 583: 3600-4 [PMID:19840792]

046. Zechel S, Werner S and von Bohlen Und Halbach O. (2007) Distribution of TRPC4 in developing and adult murine brain. Cell Tissue Res 328: 651-6 [PMID:17345099]

047. Zeevi DA, Frumkin A and Bach G. (2007) TRPML and lysosomal function. Biochim Biophys Acta 1772: 851-8 [PMID:17306511]

048. Zeevi DA, Lev S, Frumkin A, Minke B and Bach G. (2010) Heteromultimeric TRPML channel assemblies play a crucial role in the regulation of cell viability models and starvation-induced autophagy. J Cell Sci 123: 3112-24 [PMID:20736310]

049. Zhang DX, Mendoza SA, Bubolz AH, Mizuno A, Ge ZD, Li R, Warltier DC, Suzuki M and Gutterman DD. (2009) Transient receptor potential vanilloid type 4-deficient mice exhibit 
impaired endothelium-dependent relaxation induced by acetylcholine in vitro and in vivo. Hypertension 53: 532-8 [PMID:19188524]

050. Zhang E and Liao P. (2015) Brain transient receptor potential channels and stroke. J Neurosci Res 93: 1165-83 [PMID:25502473]

051. Zhang H, Sun X, Qi H, Ma Q, Zhou Q, Wang W and Wang K. (2019) Pharmacological Inhibition of the Temperature-Sensitive and $\mathrm{Ca}^{2+}$-Permeable Transient Receptor Potential Vanilloid TRPV3 Channel by Natural Forsythoside B Attenuates Pruritus and Cytotoxicity of Keratinocytes. $J$ Pharmacol Exp Ther 368: 21-31 [PMID:30377214]

052. Zhang P, Luo Y, Chasan B, González-Perrett S, Montalbetti N, Timpanaro GA, Cantero Mdel R, Ramos AJ, Goldmann WH and Zhou J et al.. (2009) The multimeric structure of polycystin-2 (TRPP2): structural-functional correlates of homo- and hetero-multimers with TRPC1. Hum Mol Genet 18: 1238-51 [PMID:19193631]

053. Zhang W, Chu X, Tong Q, Cheung JY, Conrad K, Masker K and Miller BA. (2003) A novel TRPM2 isoform inhibits calcium influx and susceptibility to cell death. J Biol Chem 278: 16222-9 [PMID:12594222]

054. Zhang W, Hirschler-Laszkiewicz I, Tong Q, Conrad K, Sun SC, Penn L, Barber DL, Stahl R, Carey DJ and Cheung JY et al.. (2006) TRPM2 is an ion channel that modulates hematopoietic cell death through activation of caspases and PARP cleavage. Am J Physiol, Cell Physiol 290: C114659 [PMID:16306129]

055. Zhang X, Li L and McNaughton PA. (2008) Proinflammatory mediators modulate the heatactivated ion channel TRPV1 via the scaffolding protein AKAP79/150. Neuron 59: 450-61 [PMID:18701070]

056. Zhang X, Li X and Xu H. (2012) Phosphoinositide isoforms determine compartment-specific ion channel activity. Proc Natl Acad Sci USA 109: 11384-9 [PMID:22733759]

057. Zhang X, Mak S, Li L, Parra A, Denlinger B, Belmonte C and McNaughton PA. (2012) Direct inhibition of the cold-activated TRPM8 ion channel by Goq. Nat Cell Biol 14: 851-8 [PMID:22750945]

058. Zhang Y, Hoon MA, Chandrashekar J, Mueller KL, Cook B, Wu D, Zuker CS and Ryba NJ. (2003) Coding of sweet, bitter, and umami tastes: different receptor cells sharing similar signaling pathways. Cell 112: 293-301 [PMID:12581520]

059. Zhang Z, Okawa H, Wang Y and Liman ER. (2005) Phosphatidylinositol 4,5-bisphosphate rescues TRPM4 channels from desensitization. J Biol Chem 280: 39185-92 [PMID:16186107]

060. Zhang Z, Zhao Z, Margolskee R and Liman E. (2007) The transduction channel TRPM5 is gated by intracellular calcium in taste cells. J Neurosci 27: 5777-86 [PMID:17522321]

061. Zhiqi S, Soltani MH, Bhat KM, Sangha N, Fang D, Hunter JJ and Setaluri V. (2004) Human melastatin 1 (TRPM1) is regulated by MITF and produces multiple polypeptide isoforms in melanocytes and melanoma. Melanoma Res 14: 509-16 [PMID:15577322]

062. Zholos A. (2010) Pharmacology of transient receptor potential melastatin channels in the vasculature. Br J Pharmacol 159: 1559-71 [PMID:20233227]

063. Zhou Y, Castonguay P, Sidhom EH, Clark AR, Dvela-Levitt M, Kim S, Sieber J, Wieder N, Jung JY and Andreeva S et al.. (2017) A small-molecule inhibitor of TRPC5 ion channels suppresses progressive kidney disease in animal models. Science 358: 1332-1336 [PMID:29217578]

064. Zhu MX. (2011) Various TRP Channels (CRC Press/Taylor \& Francis) [PMID:22593967]

065. Zhu X, Jiang M, Peyton M, Boulay G, Hurst R, Stefani E and Birnbaumer L. (1996) trp, a novel mammalian gene family essential for agonist-activated capacitative Ca2+ entry. Cell 85: 661-71 [PMID:8646775]

066. Zhu Y, Lu Y, Qu C, Miller M, Tian J, Thakur DP, Zhu J, Deng Z, Hu X and Wu M et al.. (2015) Identification and optimization of 2-aminobenzimidazole derivatives as novel inhibitors of TRPC4 and TRPC5 channels. Br J Pharmacol 172: 3495-509 [PMID:25816897]

067. Zhuang L, Peng JB, Tou L, Takanaga H, Adam RM, Hediger MA and Freeman MR. (2002) Calcium-selective ion channel, CaT1, is apically localized in gastrointestinal tract epithelia and is aberrantly expressed in human malignancies. Lab Invest 82: 1755-64 [PMID:12480925]

068. Zielińska M, Jarmuż A, Wasilewski A, Sałaga M and Fichna J. (2015) Role of transient receptor potential channels in intestinal inflammation and visceral pain: novel targets in inflammatory bowel diseases. Inflamm Bowel Dis 21: 419-27 [PMID:25437822]

069. Zierler S, Yao G, Zhang Z, Kuo WC, Pörzgen P, Penner R, Horgen FD and Fleig A. (2011) Waixenicin A inhibits cell proliferation through magnesium-dependent block of transient receptor potential melastatin 7 (TRPM7) channels. J Biol Chem 286: 39328-35 [PMID:21926172]

070. Zimmermann K, Lennerz JK, Hein A, Link AS, Kaczmarek JS, Delling M, Uysal S, Pfeifer JD, Riccio A and Clapham DE. (2011) Transient receptor potential cation channel, subfamily C, member 5 (TRPC5) is a cold-transducer in the peripheral nervous system. Proc Natl Acad Sci USA 108: 18114-9 [PMID:22025699]

071. Zitt C, Obukhov AG, Strübing C, Zobel A, Kalkbrenner F, Lückhoff A and Schultz G. (1997) Expression of TRPC3 in Chinese hamster ovary cells results in calcium-activated cation currents not related to store depletion. J Cell Biol 138: 1333-41 [PMID:9298988] 
072. Zitt C, Zobel A, Obukhov AG, Harteneck C, Kalkbrenner F, Lückhoff A and Schultz G. (1996) Cloning and functional expression of a human $\mathrm{Ca} 2+$-permeable cation channel activated by calcium store depletion. Neuron 16: 1189-96 [PMID:8663995]

073. Zubcevic L, Herzik Jr MA, Chung BC, Liu Z, Lander GC and Lee SY. (2016) Cryo-electron microscopy structure of the TRPV2 ion channel. Nat Struct Mol Biol 23: 180-186 [PMID:26779611]

074. Zubcevic L, Le S, Yang H and Lee SY. (2018) Conformational plasticity in the selectivity filter of the TRPV2 ion channel. Nat Struct Mol Biol 25: 405-415 [PMID:29728656]

075. Zufall F, Ukhanov K, Lucas P, Liman ER and Leinders-Zufall T. (2005) Neurobiology of TRPC2: from gene to behavior. Pflugers Arch 451: 61-71 [PMID:15971083]

076. Zygmunt PM, Petersson J, Andersson DA, Chuang H, Sørgård M, Di Marzo V, Julius D and Högestätt ED. (1999) Vanilloid receptors on sensory nerves mediate the vasodilator action of anandamide. Nature 400: 452-7 [PMID:10440374] 